Notre Dame Law School

NDLScholarship

Natural Law Forum

$1-1-1967$

\title{
Greek and Roman Reflections on Impossible Laws
}

David Daube

Follow this and additional works at: http://scholarship.law.nd.edu/nd_naturallaw_forum

Part of the Law Commons

\section{Recommended Citation}

Daube, David, "Greek and Roman Reflections on Impossible Laws" (1967). Natural Law Forum. Paper 125.

http://scholarship.law.nd.edu/nd_naturallaw_forum/125

This Article is brought to you for free and open access by NDLScholarship. It has been accepted for inclusion in Natural Law Forum by an authorized administrator of NDLScholarship. For more information, please contact lawdr@nd.edu. 


\section{GREEK AND ROMAN REFLECTIONS ON IMPOSSIBLE LAWS*.}

David Daube

Introduction.

I. Varia.

1. Antinomy.

2. An Athenian wit.

3. Caligula's horse and Nero's weddings.

4. The undeposable augur.

II. Interference with natural rights.

5. Pomponius on the claims of cognates to an inheritance.

6. Justinian's Institutes on the claims of children to an inheritance.

7. Gaius on agnates and cognates in connection with statutory tutorship.

8. Justinian's Institutes on agnates and cognates in connection with statutory tutorship.

9. Gaius on natural obligations.

10. Justinian's Institutes on natural laws.

III. Interference with facts and concepts.

11. Paul on possession.

12. Gaius on manifest theft extended.

13. Gaius on theft, adultery and homicide extended.

14. Gaius on usufruct extended.

15. Justinian's Institutes on usufruct extended.

16. Paul and Ulpian on usufruct extended.

17. Gaius on adoptive relations and Ulpian on conventional infamy; an excursus on in-laws.

18. Extensions by interpreters and moralists; the praetor.

IV. Interference with the past.

19. Nineteen-eighty-four.

20. "And his place shall know him no more."

21. Recognition of a freeborn citizen wrongfully kept down.

22. Creation of a freeborn citizen by the Emperor.

23. Creation of a freeborn citizen and the natural law of the beginning.

24. Creation of a freeborn citizen and legitimation by rescript.

25. Creation of a freeborn citizen and rehabilitation of an actress by rescript.

26. The rehabilitation of Theodora: Eros and Agape.

ANCIENT JURISPRUDENCE, like modern, displays much interest in unjust, immoral, unreasonable laws, but very little in impossible ones. Yet the sources contain a certain amount of material about the latter, and it may be worthwhile to present some of it.

My selection is highly subjective; I am choosing topics to which I can make some contribution within the compass of one paper. Hence I shall leave on one side the great question which has occupied Roman lawyers for the past forty years: whether, whereas the Greeks put their trust in legislation,

- This article is a revised version of an address given at the ninth annual meeting of the Board of Editors of the Natural Law Forum. 
in the Rome of the Republic and constitutional monarchy law was essentially identified with custom, which legislation was not at liberty to overthrow. Roman statutes often end with a clause to the effect that there is no intention to abolish established law, ius, that ought not to be abolished. For Mommsen, the legislature was sovereign, so this clause was a voluntary selflimitation.1 For Rotondi and Arangio-Ruiz, the legislature might only either define custom or order peripheral matters, so the clause was a necessary reservation, one which would operate even without it. ${ }^{2}$ For Mommsen, Cicero's contention that no statute could deprive a citizen of his freedom ${ }^{3}$ was an advocate's exploitation of that clause; for Rotondi and Arangio-Ruiz it was absolutely correct, indeed, freedom was only one of innumerable things no statute could touch. While Mommsen was perhaps too radical in one direction, the opposite view has its own difficulties. It is, for example, hard to reconcile with the system of legis actio as it prevailed at some stage at least during the Republic, when any claim to be tried had first to be pleaded before a magistrate in words exactly following those of a statute. There are, of course, scholars holding positions intermediate between the extremes.

I propose to begin with some desultory remarks, chiefly designed to convey an impression of the manifold guises the problem of impossible laws may assume. The cases offered are not, however, devoid of intrinsic interest. The exchange between Antisthenes and his fellow citizens whose legs he pulled is to my knowledge the earliest extant discussion of the problem anywhere.

Next I shall examine the assertion made by a number of Roman jurists that the civil law has no power over the rights of blood relations. No practical consequences were drawn from this doctrine; it is an illustration of a rather rare phenomenon in classical law, philosophical embellishment. Blood relationship - as opposed to the agnatic relationship between those who are in the same patria potestas or would be if the common ancestor were still alive - did not become important in private law till the late Republic. The regulations having regard to it were inevitably laxer than those having regard to agnatic relationship. Moreover, in Greek speculation, taken over by the Romans, the ties of blood were prominent among the sources of obligations no human lawgiver might invalidate: Antigone cannot leave "her mother's son" unburied ; 4 it is her case which Aristotle in his Rhetoric quotes first to

1 Römisches Staatsrecht vol. 3, pt. 1, 42f. (1887).

2 Rotondi, Problemi di Diritto Publico Romano, 1 Scritri Giuridici 370ff. (ed. by Arangio-Ruiz, 1922). [44 Rivista italiana PER Ie scienze giuridiche 147ff. (1920)]. The article appeared posthumously. Arangio-Ruiz, La Regle de Droit et la Loi dans L'Antiguité Classique, 29 L'EOYPTE contrmporaine 30f. (1938), reprinted in Rariora 252ff. (1946).

3 Crcero, Pro Caecina 33.95ff., De domo sua $29.77 \mathrm{ff}$.

- Sophocles, ANtigone 466f. 
illustrate what is naturally just though prohibited $;^{5}$ and Cicero defines piety, which is a sector of the law of nature, as the duty owed to one's country, one's parents, and one's other relations by blood. ${ }^{6}$ When we consider, in addition, that even at Rome, in religion, fas, and in personal life; blood relationship had always been of the greatest moment, the pronouncements in question will not appear too surprising.

I shall go on to the denial by a school of Roman jurists of a lawgiver's power to extend to new situations a concept like theft, homicide, usufruct. In this case, the debate no doubt did involve practical considerations, at least in respect of the earlier instances; it is possible that in course of time the academic-linguistic side took over. What is remarkable is how the jurists - both those who object to the transfer and those who, up to a point, accept it - treat these terms of theirs in their traditional application as in accordance with nature, like, say, silence, noise, a house, a horse. To widen them is to misrepresent reality (thus those who decline the extension), unless the widened term is looked on as a different, additional one (thus those who admit the extension).

Finally I shall introduce a variety of impossibility which has so far received scant attention: laws intended to change the past. I shall say something about the so-called damnatio memoriae, which might go as far as to make a hated ruler not to have ruled. Above all, I shall investigate the rectification of servile birth. Even today, in societies less keen on the self-made man than in America, humble antecedents are apt to be covered up. At Rome, there were several ways in which a freedman might conceal his origin. From the formalistic-legal point of view, from the early Empire onwards, there was less need for it since, as far as public, political life was concerned, the Emperor could grant him most of the privileges of a freeborn citizen. But that was still not good enough, and from the second half of the second century the Emperor could make him freeborn. In a statute enacted by Justin, the uncle of Justinian, this idea of the conferment of free birth combines with the religious idea of the restoration of sinners to form the basis for a grant by which the Emperor may rehabilitate penitent actresses and cleanse them of their tainted past. By this statute Justinian was enabled to marry Theodora. 7

S Aristotle, Rhetoric 1.13.2.

- Crcero, De inventione 2.22.66, 53.161.

7 Recently Lon L. Fuller, in his book The Morality of Law 70-79 (1964), has devoted a valuable chapter to "Laws Requiring the Impossible." On the whole, however, the area he has in mind is not the same as that considered in this article. For instance, he deals with strict civil and criminal liability, which may (though, surely, it need not) be understood as implying a command of the impossible. Moreover, he seems to include relative impossibility. If my material lends itself to a different approach, this does not mean that his treatment is not perfectly appropriate to the problems with which he is concerned. 


\section{VARIA}

1. Antinomy. - Perhaps at the outset attention should be drawn to the fact that a considerable sector of the art and rules of interpretation of statutes is designed to get rid of "logical" impossibility, the existence of which jurists are unwilling to admit. Suppose there are two laws, one which forbids a man convicted of extortion to speak in the assembly and another which orders an augur to designate in the assembly the successor to a deceased colleague; now an augur convicted of extortion makes a nomination in the assembly - a case recorded in Ad Herennium. ${ }^{8}$ Somehow the two leges contrariae must be reconciled so as to allow a decision about the case. As a rule, the premise that such a conflict is not real, can be only apparent, is tacitly assumed - but not always. Quintilian, for example, formulates it in so many words: "It is obvious to all that one statute can never contradict another as to the law as such since, if the law as such were different, the one would cancel the other."9

One can see that in a well-working legal system this consequence - that one would cancel the other - would be most awkward. We ought to be clear, however, that it would not be intrinsically untenable. With regard to two contradictory testamentary dispositions, the Roman ruling was indeed that neither of them was valid. ${ }^{10}$ Strangely, most philosophers believe that there cannot be several quite inconsistent moral duties binding at the same time. If they were right, there would be no genuine moral drama; a little more analysis and everything will be in order. True life is less simple.

At any rate, it is partly due to the role of interpretation that we hear so little about impossible laws (partly - there are other reasons too): defects of the kind indicated, logical discrepancies and the like, are construed away.

As for laws requiring the practically impossible, they are far rarer than, say, contracts of this description; nor do they easily lead to litigation. (Among things practically impossible the Romans reckoned the touching of the sky with one's finger, 11 as did whoever coined the phrase "to cry for the moon": tempora mutantur.) They do play a certain part in fairy tales and nightmares, and, indeed, in theology. But I shall omit the entire complex referred to by the apostle Peter as "the yoke which neither our fathers nor we were able to bear,"12 except to say that the long and rich jurisprudential history behind it is virtually unexplored. That the impossible order of a judge is

- Rabtorica Ad Herennium 1.11.20.

- Quintilian, Institutio Oratoria 7.7.2.

10 Drozst $50.17 .188 \mathrm{pr}$, Celsus XVII digestorum.

11 Institutes 3.19.11.

12 Acts 15.10 . 
void, and that a judgment which by the nature of things, rerum natura, cannot be obeyed is so lacking in force that there is no point in an appeal, is noted by the jurists. ${ }^{13}$

2. An Athenian Wit. - Now for a few cases outside the more familiar legal literature.

Antisthenes, an older contemporary of Plato, rocommended to the Athenians to vote that asses were horses. To the objection that that was absurd he retorted: "Yet there are generals in your city who have no experience but are merely elected."14

It is clearly the agreed basis between the parties that there can be no legislation for the absolutely impossible: asses are horses. At this juncture it is immaterial for us whether the accent lies on the flaw in perception, i.e., the error in declaring something to be something that it is not, or - what is more probable from the context - on the practical impossibility of turning one natural species, a useless one, into another which is of use. ${ }^{15}$ I leave aside (since it is not ventilated by the text) the case where such a statute might make sense, namely, if it decrees that something, hitherto falling under suchand-such rules, equals something else, falling under other rules. We shall have to deal with this case below in connection with extensions of furtum manifestum and usufruct.16 One is reminded, of course, of Parliament, which can do anything except make a man into a woman, yet in a sense can do even this.

Antisthenes's conclusion, however, is reached by a sleight-of-hand. He was a precursor of the Stoics and - as this anecdote illustrates - shared features with the Sophists. He steps from the impossible to the unreasonable, same reasoning it is also like an ass."

to the conferment of a status and function on someone unworthy. The trick is cleverly obscured by focusing on the common element, i.e., the contrast between the inferior, stupid, untrained, and the superior, valiant, disciplined. This contrast is the same whether we think of asses and horses, or of people who have never learnt the art of soldiering and proper militaries; and the emphasis on it is designed to make us overlook the difference - that while it is impossible to turn asses into horses, it is merely foolish to appoint an in-

13 Drarst 49.8.3, Paul XVI responsorum.

14 Diogrnes Lneritius, Lives and Opinions of Emingnt Philosophers 6.8 .

15 Horse and ass were apparently a favorite illustration of the efficient and the inefficient. In Plato, Prandrus $260^{\mathrm{b}}$, the accent lies on the ignorance as to which is which, leading to harmful consequences. The ass can be relied on to deflate solemnity. In Droest 15.1 .40 at the beginning, Marcian V regularum, we are told that a peculium "is born, declines, dies" and that, therefore, Papirius Fronto "elegantly remarked that it resembled a man." Stein points out (Elegance in Law, 77 LAw QuARTerLy Review 249 [1961]) that Accursius in his Gloss shows scant respect for such elegance: he notes eadem ratione et asino, "by the

16 Infra, pp. $25 f$. 
adequate leader. Any two natural species would not have done for the joke. It would not have done to recommend to vote that lions were tigers or that asses were mules: as lions and tigers are both splendid and as asses and mules are both despised, these proposals would have lacked that tertium comparationis with the election of the generals (to wit, the contrast between the inferior and the superior) which gave the analogy its convincing look.

It is noteworthy that the term used in the objection to Antisthenes's proposal is alogon, "absurd." It is a good choice: it is general enough to cover the whole field, the unreasonable as well as the impossible. ${ }^{17}$ Which again facilitates the translation from the latter to the former.

3. Caligula's Horse and Nero's Weddings. - Caligula, when he consecrated himself priest in his own service, made his favorite horse a fellow priest, ${ }^{18}$ and, had his reign not taken a premature end, he would have made him consul as well.19 (In the recent play The Horse, by the Hungarian author Julius Hay, he is enabled to execute his design, with amusing results.) This horse should figure prominently in any history of legal personality: he was given a furnished house and slaves, for the entertainment of guests invited to the races in his name. Suetonius writes that "besides a marble stall and an ivory manger, and besides purple blankets and a collar of jewels, Caligula gave him also a house, his own slaves and furniture." The structure of the sentence indicates a clear distinction between gifts which, however extravagant, imply no serious assimilation to a free man's status, and house, slaves and furniture which do. 20

The elevation of a horse to the priesthood or consulate no doubt goes further than the appointment of bad generals. To the ordinary onlooker at least it seems to trample on the offices in question, to empty them of any content. Nevertheless it is possible in that the law; sacred or secular, can lay down what an office is to mean and who is able to hold it.

The Roman historians from whom we get our information are equally outraged by the gifts to the horse and its promotion to or destination for office. For them, Caligula constantly overstepped the bounds of decent or even sane conduct; he posed as Jupiter, Neptune and so forth. ${ }^{21}$ It is chiefly

17 See Daube, Le raisonnement par l'absurde chez les jurisconsultes romains, lecture delivered at the Institut de Droit Romain, Paris, 1958 (mimeographed). In the passage from the Phaedrus quoted above, the exposition of an orator who does not know what is a horse and what an ass is called geloion, "ridiculous"-practically synonymous with alogon, "absurd."

18 Dio, Roman History 59.28.6.

19 Suetonius, Caligula 55.3; Dio 59.14.7.

20 Sugtonius, Caligula 55.3. Dio 59.14.7 does not mention this particular wildness, but here Caligula invites the horse to dinner and drinks his health.

21 Seneca, Dio, Philo, Josephus, and probably also Statius regard him as lunatic; Tacitus and Suetonius use slightly weaker language, though the latter speaks of insania (55.1) in describing Caligula's excessive devotion to his actor friends. 
Caligula whom the German word Caesarenwahnsinn calls to mind; it was coined by Gustav Freytag22 and achieved wide currency through Wiedemeister, who wrote as a medical. To judge fairly, however, we must remember the wider background of deification of rulers, such old stories as Xerxes having the sea lashed for insubordination, ${ }^{23}$ ideas which, long prevalent in the East, were now rapidly gaining ground in the West. After all, the Jews were the only nation not to acknowledge Caligula as god. ("Are you the god-haters" he greeted Philo and his fellow ambassadors,"24 "who do not believe me to be a god, though I am acknowledged as such by all the other nations, and you refuse me the name?") From that - supernatural - angle, much that otherwise appears insensate is less so, and even the turning of one natural species into another would not be quite impossible. It is hardly accidental that the horse's career started with a religious honor; the consulate would have come second.

The Emperor sensed that the jurists, an unimaginative lot, did not like his doings. He threatened that he would abolish their art and at any rate make sure no opinion contrary to his wishes could be given. ${ }^{25}$

Nero took Pythagoras to "husband" and Sporus to "wife"28 - transactions on about the same level as the conferment of priesthood or consulate on a horse. Our historical sources are enraged, it is all wicked, monstrous. Of course the sober ones among the Romans saw precisely how the traditionally accepted essence of matrimony was thereby infringed: a bon mot went round that it would have been a good thing if Nero's father had contracted such a marriage - a sterile one. But again, there is more to it. Admittedly, despite dowry, ceremonies, etc., these marriages were not meant quite seriously, were not looked on as of full legal validity - not even in the sense of a noncivil marriage; a matrimonium non iustum. But neither were they simply mad pranks. Various religions, especially sects based in the East, provided models: nature could be overcome. We are told that, in uniting as "wife" with Pythagoras, Nero behaved like a deflowered maiden, cried and so forth. Sporus looked like the deceased Poppaea Sabina (whose death Nero had caused by a kick ${ }^{27}$ ); was perhaps regarded as a kind of Sabina rediviva. ${ }^{28}$

22 G. Freytag, Dig verlorene Handschrift. Freytag refers to Tacitus's chapters on Tiberius and Claudius.

23 For Caligula's emulation of Xerxes, see Sugtonius, Galroula 19.3; Dio 59.17.7ff., 59.25.3.

24 Philo, Legatio ad Gajum 44.353; cp. 45.367, and Josephus, Antiguities 18.8.258, 19.5.284.

25 Surtonius, Caligula 34.2. Hitler's $T_{\text {Able }} T_{\text {Alk, }}$ by the way, evinces an obsessive hatred of lawyers.

26 Tacitus, Annals 15.37; Sugtonius, Nero 28f.; Dio 68.28.3, 62.13.1, 63.22.4.

27 Tagrtus, Annals 16.6; Subtonius, Nero 35.3; Dio 62.27.4.

28 Compare Dio 63.9.5: women's masks in plays were sometimes given the features of 
At any rate Nero had him castrated "and even tried to transfigure his nature into that of a woman."29 In Greece people prayed for progeny from this union.

Martial, after Nero, satirizes a ceremonious "marriage" between two perverts. ${ }^{30}$ The torches, the veil, the wedding songs, the dowry - nothing was omitted. He adds: "Is this not enough for you, Romans? Or are you now waiting for an accouchement?" Back of this verse there is not only the old bon mot about Nero, but also the more serious expectations enthusiasts had entertained.

4. The Undeposable Augur. - Before going on to the jurists, I would mention one of Plutarch's Roman Questions: ${ }^{31}$ why is an augur absolutely undeposable - even should he be exiled as a criminal? One answer supplied is that "augur" denotes not the office but the skill. To depose an augur would therefore be like voting that a musician is not a musician, a physician not a physician.

There is no need to dwell on the unsatisfactoriness of this solution, which would clearly create quite a few augurs over and above those properly appointed: anyone with the requisite knowledge would be an augur. What is, however, neatly brought out is the distinction deliberately blurred, we saw, by Antisthenes: the factual belonging to a species (ass, horse, musician, expert in augury) is not subject to a decree; the belonging to a rank (general, priest - if we mean just the rank of priest, not the skill) is.

\section{INTERFERENGe WTTH NATURAL Rights}

5. Pomponius on the Claims of Cognates to an Inheritance. - Pomponius, in his discussion of bonorum possessio, the praetorian scheme of succession, explains that where capitis deminutio minima - such as emancipation from patria potestas, the head of the family's power-prevents a claim unde legitimi, based on civil, statutory law, there may still remain a claim unde cognati, based on blood relationship: "the rights of blood," he adds, "can through no civil law be destroyed." 32 The statement is one of many concerned with the effect, or lack of effect, of positive or civil law on natural law or facts. ${ }^{33}$

Sabina "in order that, though dead, she might still take part in the spectacle." On the other hand, he kept a courtesan resembling his mother Agrippina while the latter was yet alive. Suetonius, Nero 28.2; Dio 62.11.4.

29 SUetoniUs, Nero 28.1: "etiam in muliebrem naturam transfigurare conatus."

so Martial, Epigrammata 12.42.

31 Plutarch, Roman Questions 99.287E.

a2 Drosst 50.17.8, IV ad Sabinum: "iure sanguinis nullo iure civili dirimi possunt." For the original context, see LENel, 2 Palingenesia iURis civilis 93 (1889).

83 Voigt's extensive inquiry into the history of the problem is still indispensable: DAs 
The statement is not correct. If the civil law so wishes, it can destroy the rights of blood; and, in fact, in some cases it does so. The claim unde cognati does not, for example, survive capitis deminutio maxima, loss of liberty, or even media, loss of citizenship, say, through exile or deportation. True, the law cannot turn a relation into a nonrelation, an ass into a horse. But, pace Pomponius, it can deprive a relation of all a relation's rights. Even capitis deminutio maxima does not turn a relation into a nonrelation, though before the law the former is now like the latter - his rights are gone.

It might perhaps be argued that capitis deminutio maxima and media are closer to natural law, of which Pomponius would not deny that it can destroy the rights of blood. But this is a lame excuse. Moreover, there are other cases which should have given him pause. An incestuous begetter of offspring does not count as father, the offspring not as his child; and, remember, it is incest for a man to "marry" his adoptive daughter - indeed, it makes no difference if the adoptive tie is dissolved.94 The offspring of such a union, being a bastard, has no claim unde cognati to his begetter's estate. So here the civil law prevents the rights of blood from even coming into existence. Again, prior to the lex Minicia, the child of a Roman mother and an alien father was a Roman; a child born from such a marriage after that statute was an alien - entirely outside the praetorian scheme which was confined to citizens, unable to invoke either unde legitimi or unde cognati. ${ }^{35}$

One might try an entirely different defense of the jurist. The remark in question is preserved in title 50.17 of the Digest, De diversis regulis iuris antiqui. We know that many texts in it have been slightly adjusted by Justinian with a view to obtaining a general regula. ${ }^{36}$ One might ask, therefore, whether the inexactitude is not due to Justinian, Pomponius having expressed himself more circumspectly. But this is most unlikely in view of the fact that, as we shall see, ${ }^{37}$ his contemporary Gaius repeatedly commits a similar blunder, at least once in his Institutes, untouched by Justinian, and that it is indeed Justinian who on this occasion tries to put it right. 38

It is easy to guess what Pomponius is driving at. The actual presence of cognation, blood relationship, cannot be abolished by any law; no law can

Jus naturale, 4 vols. (1856-75), especially vol. 1 (1856), pp. 303ff. See also Ernst Levy's great lecture, Natural Law in Roman Thought, 15 StUdis ET DocumbntA HisTORIAE ET IURIS 1-10 (1949).

84 Gaivs 1.59, 64; Institutes 1.10.1, 12; Dioest 23.2 .55 pr., Gaius $X I$ ad edictum provinciale.

35 Gaius 1.78; Ulpiani Rggulae 5.8.

86 See Daube, $Z_{u r}$ Palingenesie einiger Klassikerfragmente, 76 ZeIrschrift dgr SAvionyStiptuno 198ff. (Roman section) (1959).

${ }^{87}$ Infra, pp. 13ff.

s8 Gaivs 1.158 ; INstitures $1.15 .3,1.16 .6$. See especially pp. $17 f$. 
turn a relation into a nonrelation: 39 Further, though the rights flowing from cognation, the rights of blood, can be abolished, that does not in fact happen as a result of capitis deminutio minima, a mere civil law change of family status. The distinctively Roman, civil law relationship of agnation, the relationship between those who are in the same patria potestas, or would be if the common paterfamilias were still alive, is indeed dissolved by such a change; it is of its very essence that it should be. At one time, private law took little notice of cognation. Now, however, that the praetor does recognize it as a source of rights, natural rights as opposed to the old civil law ones, he is only consistent in not admitting grounds of extinction peculiarly connected with the old civil law relationships. That would vitiate the main purpose of his innovation: Something like this is the - considerable - grain of truth in Pomponius's remark.

It would be a mistake, incidentally, to think that, by Pomponius's time, capitis deminutio minima has become a technicality with negligible practical consequences. It has not. A son emancipated, for instance, can own property of his own; the seriousness of which consequence is underlined by the praetor's request, on according him a claim unde liberi together with a son still in potestas, to make collatio bonorum, to bring in his possessions. The reason capitis deminutio minima is discounted when it comes to unde cognati is not that it is unimportant in itself, but that, however important, it is the kind of transaction which, where cognation is the decisive tie, it is appropriate to discount, and which, unlike, for example, deportation, one can afford to discount.

Little damage was done by a statement like that here reviewed. The classical jurists on the whole refrained from enunciating philosophical maxims. The few we do find tend to be commonplaces, repeated again and again. Their function is to justify (after a fashion) an existing state of law. Beyond that, they are merely decorative; no real inferences were drawn.

6. Justinian's Institutes on the Claims of Children to an Inheritance. Institutes 3.1.11, according to Ferrini, 40 comes from the Res Cottidianae rightly or wrongly attributed to Gaius. ${ }^{41}$ We learn that true children emancipated, while the emancipation costs them their civil law claim to their father's

39 In reality, even cognation by the time of Pomponius was no longer as simply factual as that: it covered adoptive relatives so long as the agnatic tie lasted. Diczst 38.8.3, Julian XXVII digestorum, 38.8.1.4, Ulpian XLVI ad edictum. I disregard this complication.

¿o Ferrini, Sulle fonti delle Istituzioni di Giustiniano, 2 Oprre 379 (ed. by Albertario, 1929). (This reference is the same as 13 Bullettino dell' Istituto di Diritto Romano 166 [1900].)

41 Jolowicz, for example, inclines to regard the attribution as wrong or, shall we say, exaggerated (Hustorical Introduction to Roman Law 398 [2nd ed., 1952]). Honoré argues that it is right (Garus 113ff. [1962]). I am not convinced by the latter. 
estate, are given a claim unde liberi by the praetor; adoptive children emancipated are not only without a civil law claim to their adoptive father's estate but also get no praetorian claim unde liberi. The text goes on: et recte, "and rightly." Why? Because "a civil law reason cannot destroy natural rights, and true children or grandchildren cannot cease to be children or grandchildren by ceasing to be sui heredes." 42 By contrast, "adoptive children, as they obtain the right and name of a child by the civil law reason of adoption, so they lose them by another civil law reason, emancipation."43

This is the same mix-up as in Pomponius, except that the natural tie in question is not cognation in general, but the more specific one between father and child. Moreover, as in Pomponius, it occurs in the context of the effect of capitis deminutio minima on bonorum possessio.

The author of the passage is right in saying that a true child does not lose this quality by ceasing to be a suus heres. But he is slipping when he says that a true child's natural rights - the claim unde liberi-cannot be destroyed by a civil law transaction. It is indeed astonishing he should be so enamored of his theory as not to realize its brittleness. There is the glaring fact that an adoptive child, while in his adoptive father's potestas, has no claim unde liberi to his natural father's goods.44 Moreover, though a child emancipated by his adoptive father regains unde liberi in his old family, or as Paul puts it, regains the ius naturale liberorum, "the natural right of children," 45 in the very paragraph preceding that under discussion, in Institutes 3.1.10 - equally, according to Ferrini, from the Res Cottidianae - an exception even to this right is noted. For a sound reason of expediency, even a child emancipated by his adoptive father and thus no longer under his potestas, if the emancipation takes place after the natural father's death, is refused a claim unde liberi to the latter's estate. The reason is that it should not be within the adoptive father's discretion, on the natural father's death, to place or not to place a liber ahead of the legitimi, the agnates. Plainly, if it were, he could make some unscrupulous deals. ${ }^{46}$ Yet this rule is followed by the statement that the natural rights of liberi are unabolishable by the civil law.

42 Naturalia enim iura civilis ratio peremere non potest nec, quia desinunt sui heredes esse, desinere possunt filii filiaeve nepotes neptesve esse.

43 Ius nomenque filii filiaeve, quod per adoptionem consecuti sunt, alia civili ratione, id est emancipatione, perdunt.

14 Ulpiani Regulae 28.8.

45 Dicesr 38.6.4, Paul II ad Sabinum. For the probable scope of Paul's statement, see infra note 46.

46 In Institutes 3.1 .10 as it stands, the exclusion from unde liberi in the old family is confined to adrogatio, more precisely, to a child first emancipated by his true father, then giving himself in adoption - adrogatio - and finally emancipated by his adoptive father. In the Res Cottidianae, the exclusion cannot have been so confined. It must have covered 
It may be added that the remark at the end of the quotation, about adoptive children, is also far too simple: emancipation of an adoptive child, it is affirmed, deprives him of unde liberi in the adoptive family because what is gained by a civil law transaction is lost by a civil law transaction. There is no inevitability about this; but there were good grounds for attaching unde liberi in such a case to the original family. I shall not, however, pursue this matter.

Let me call attention to the interesting phrase ius nomenque, "right and name," where nomen has the connotation of something artificial, superimposed, "mere name," by contrast with the genuine, natural: adoptive children are children "by mere title of law." We shall come across two more instances of this use of nomen, Gaius 3.21 and Institutes 1.15.3.47 To be exact, Gaius 3.21 speaks of nomen agnationis, "the name of agnation." The combination with ius occurs only in Justinian. Between ius nomenque in 3.1.11, descriptive of an adoptive child's position, and iuris nomen in 1.15.3, descriptive of agnation (nam adgnatio iuris est nomen), there seems to be little difference; the meaning is "a mere name, title, conferred by the law." Institutes 3.1.11, as mentioned above, probably comes from the Res Cottidianae, Institutes 1.15.3 in the main reproduces Gaius 1.158 , but the relevant clause is an addition, be it by Justinian, be it by a pre-Justinianian reviser of Gaius.48 In any event, as far as the extant textual evidence goes, the combination of nomen and ius in this area is later than Gaius's Institutes. ${ }^{49}$

One reservation is called for. After observing that the praetor discriminates between true and adoptive children, Institutes 3.1.11 continues: et recte, "and rightly." The opposite of what is done recte, I feel, is wrong,

also a child given in adoption (in the narrow sense, not adrogatio) by his true father and then emancipated by his adoptive one. For Justinian, as a result of his great reform of adoption (in the narrow sense), InstrTutzs 1.11.2, Codex 8.47.10 of A.D. 530, this case no longer falls within the area of the rule at all: adoption (in the narrow sense) now leaves the rights of succession in the old family quite unaffected. Hence the curious restriction of the rule to adrogatio. Doubtless Diges T 38.6.4, Paul II ad Sabinum, too, has been brought into harmony. with his legislation; in the classical version, the portion sed si naturales ... now restricted to adrogatio, was certainly wider. My comments on INSTITUTEs 3.1.11 do not, however, depend on the exact scope of 3.1.10.

47 Infra, pp. 14, 17.

18 Frreini, 2 Opere 344 (13 Bullettino dell' Istituto di Diritto Romano 135) takes the latter view: it is a gloss that got into GAIUs 1.158 prior to Justinian.

to Theophilus, incidentally, simplifies ius nomenque in 3.1.11 by omitting ius; he translates to onoma. In 1.15 .3 he translates nomimon onoma, agnation is "a legal name." Strangely, Ferrini in his Latin version of Theophilus, Instritutionum Graeca Paraphrasis Theophilo ANtecessori vulgo tributA, pt. 1 (1884), 70, retains a gross vulgarization introduced by previous modern editors, namely, the insertion of civilis. He renders iuris enim civilis nomen adgnatio est, "for agnation is a title of the civil law." This gets rid of the not very easy concept of iuris nomen and, in the process, robs the clause of any interest, makes it state the excessively obvious. (As a matter of fact, in his version as it stands the word nomen does not appear at all; we read iuris enim civilis adgnatio est. I 
incorrect, improper rather than impossible. Accordingly, this kind of approval soems to imply that the praetor could have treated the two classes of children alike though, had he done so, he would have made a mistake; still, it would have been valid if objectionable law. It is, then, only when the et recte is being expanded, substantiated by a slogan, that confusion sets in. That the confusion did no harm, since no attempt was made to lift it from the sphere of theory, I have already pointed out in discussing Pomponius.

7. Gaius on Agnates and Cognates in Connection with Statutory Tutorship. - In Gaius's time a boy under age (normally, under 14) who was sui iuris - without a paterfamilias - had a guardian, often one appointed in the dead paterfamilias's testament; in default of such a one, the nearest agnate was his guardian. In expounding this tutela legitima, which goes back to the XII Tables, Gaius in his Institutes writes that "the right of agnation, though not that of cognation, is destroyed by capitis deminutio."50 He is thinking of capitis deminutio minima (media or maxima would wipe out the right of cognation as well). From the destruction of agnation by this it would follow, for example, that a person otherwise the nearest agnate, if he got himself adopted by another family, would no longer become guardian or, supposing the adoption took place after he had become guardian, would cease to be guardian.51 Gaius continues by explaining why cognation survives capitis deminutio: "whereas civil law rights can be extinguished by a civil law reason, natural rights cannot."52

Basically, this is again the same muddle, this time in the context of the effect of capitis deminutio minima on tutela legitima. The natural tie in question is cognation, as in Pomponius; in Institutes 3.1.11 it is the tie between father and child. However, we shall see that, in several respects, Gaius's presentation is worse than that of the other two texts.

Basically, then, it is the same muddle: the misconception that natural rights are indestructible by the civil law. In reality, they are destroyed by capitis deminutio maxima or media and could be destroyed whenever the legal order so decreed. (This has, of course, been seen.) ${ }^{53}$ Gaius himself mentions the

assume, however, that it has dropped out through a slip on his or the printer's part. The edition is notorious for its misprints: Zachariä von Lingenthal, review of Institutionum etc., 5 Zeitschript der SAviony-Stiftuno 276 [1884] [Roman section]).

so Gaivs 1.158 .

51 Ulpiani Regulae 11.9.

52 Sed agnationis quidem ius capitis deminutione perimitur, cognationis vero ius eo modo non commutatur, quia civilis ratio civilia quidem iura corrumpere potest, naturalia veto non potest. Beseler, 5 Bertrǘte 2 (1931), in a general attack on ratio, brackets the relevant passage from quia, "whereas civil law rights. . "This is unacceptable. Compare, infra, pp. 19ff. on Dioss 1 4.5.8, Gaius IV ad edictum provinciale, and pp. 34ff. on Digest 7.5.2.1, Gaius VII ad edictum provinciale.

s3 See, e.g., Voicr, op. cit. supra note 33, at 306; Poste, Gat Institutiones 926. (4th ed., 1904). 
incestuous nature of a union with an adoptive daughter, with the result that any offspring would be a bastard ${ }^{54}$ not tied to his begetter even by cognation. As for the provision of the lex Minicia making the child of a Roman mother and alien father an alien, Gaius himself points out ${ }^{55}$ that this overturned the ius gentium, which he regards as resting on naturalis ratio $;^{56}$ and a little further on he observes more generally that the principle of the ius gentium that a child follows the mother is subject to legislative modification. The example he cites is interesting: a senatusconsult - Claudianum - had decreed that if a free woman has the owner's consent to cohabit with his slave, she herself would remain free but the offspring would be slaves; Hadrian found this "inelegant" - though by no means impassible - and restored the ius gentium, a child would share the mother's status. ${ }^{57}$ I agree with Levy against the prevalent opinion, that in classical times ius gentium and ius naturale were not synonymous: "The one stated the fact of universal usage, the other its motivation. Moreover, while ius gentium was a hard and fast category indispensable to the technique of the jurists, naturalis ratio never obtained an organic status in their reasoning." 58 It is partly because of this vagueness of the latter notion that a misconception like that presented could come about.

The misconception recurs in two passages in Gaius's chapter on succession, though it is here less fully formulated. Commenting on the law of the XII Tables he observes that, under that code, an agnate having undergone capitis deminutio - again, the reference is to minima - is not admitted to the succession, "since the name of agnation is destroyed by capitis deminutio." 59 The contrast with cognation is not expressly drawn, but it clearly underlies the description of agnation as a nomen, "name." As in Institutes 3.1.11 just discussed, where we hear of the ius nomenque of an adoptive child, so in this passage "name" means "mere name," "mere civil law title," as opposed to the real, natural thing, in this case cognation. 60 The implication, then, is that the position of a cognate could not be affected by capitis deminutio.

Further on, dealing with the praetorian improvements, Gaius does contrast agnation and cognation expressly. The praetor reserves a place in his scheme for cognates (though they still rank below agnates). Agnates having undergone capitis deminutio may still have a chance in this class since, Gaius explains, "though they have lost their statutory right, assuredly they retain

$541.59,64$.

561.78 .

$561.1,189$.

57 1.83f.; see Stein, op. cit. supra note 15, at 248.

58 Levy, op. cit. supra n. 33 at p. 11.

69 Gavus 3.21, quia nomen agnationis capitis deminutione perimitur.

6o Compare also Instrtutes 1.15 .3 , to be considered presently. 
the rights of cognation."61 He does not say merely that they retain the rights of cognation. They do so certe, "assuredly," "obviously." Once more, what is implied is that these are rights which cannot be touched by a civil law transaction.

To return to his remark on tutela legitima, the muddle is less tolerable than in Pomponius and Institutes 3.1.11 in two respects. First, prima facie, from his presentation it looks as if the rights flowing from cognation survived even capitis deminutio maxima and media. He declares these rights to be unaffected by capitis deminutio - he does not specify, he does not put minima. Ordinarily, to be sure, it might be left to the reader, even a student reader, to notice that minima alone is intended. But in the present case, this is very slipshod, considering that, in the very next paragraph, he defines capitis deminutio as a change of civic condition, adding that it can be maxima, media, or minima. ${ }^{62}$

Secondly, the remark, correct or incorrect, is rather out of place. In the case of succession, the subject of Pomponius and Institutes 3.1.11, a person having dropped out of agnation, unde legitimi, may sometimes nevertheless have a claim based on cognation, unde cognati, or more narrowly, on his quality as child, unde liberi. But there is no tutela of cognates. Accordingly, whereas it is useful to point out the contrast between agnation and cognation, and stress the possible retention of the latter when the former has gone, in a discussion of succession - as also, perhaps, in one of capitis deminutio in general or of capitis deminutio minima ${ }^{63}$ - it is not very relevant here. Certainly, where, in the absence of both a testamentary guardian and a legitimate one, an appointment is made by the magistrate, he will often in fact appoint a cognate. This may safely be assumed - from general considerations, from the ever-increasing part played by cognation, from the obligation of cognates (at least some of them) if necessary to request an appointment, from their role in nominatio potionis which came in soon after Gaius. But all this in no way brings in cognates as a technical class. The financial suitability of a cognate, for instance, would be more important than his nearness in degree. Moreover, friends of the family, too, would come into consideration.

What makes the remark particularly inapposite is the fact that, by the second century A.D., it is no pleasure to get the appointment. Indeed, the trouble and risks are enormous. A legitimate guardian, an agnate, is perhaps still relatively free from duties. (Namely, if we reject as spurious the texts

61 3.27, Licet enim capitis deminutione ius legitimum perdiderint, certe cognationis iura retinent.

621.159.

6s But we do not really find it even in Drosst 4.5 .7 pr., Paul XI ad edictum, and 4.5.8, Gains IV ad edictum provinciale: see infra, pp. $19 \mathrm{fr}$. 
assimilating him to the guardian appointed by the magistrate. The matter is controversial.) For a guardian appointed by the magistrate - a cognate, a friend of the family - the office is definitely a burden. In a sketch of guardianship, therefore, to speak of "a right of cognation" - "though the right of agnation is destroyed by capitis deminutio, the right of cognation is not because a civil law transaction cannot destroy natural law rights" - is schief, thoughtless.

Below I shall quote a text from the Digest deriving from a section of Gaius's commentary on the provincial edict which deals with capitis deminutio minima. ${ }^{64}$ Here he again proclaims the doctrine of the resistance of natural rights to civil law transactions, and though the doctrine is wrong, at least it is not misplaced. ${ }^{65}$ In the Institutes Gaius, first-rate teacher, second-rate jurist, enlivens his résumé by a commonplace maxim though it does not fit. Perhaps in the older work which he follows, ${ }^{66}$ to be guardian still appeared as an advantage rather than a bother - which would make his talk of ius cognationis more pardonable. After all, right to the last we can spot traces of the original character of guardianship, if only in vocabulary. ${ }^{67}$ Or he may have at the

64 Digest 4.5.8, Gaius IV ad edictum provinciale; for the original context, see Lenel, 1 Palingenesia iuris civilis 197 (1889).

65 It might perhaps be argued that the paragraph from the Institutes here analyzed should be read, not together with what precedes it, as part of the discussion of tutela legitima, but together with what immediately follows, that is to say, as opening the excursus on capitis deminutio which Gaius inserts in the chapter on guardianship. In an account of capitis deminutio, as already observed, the contrast between agnation and cognation does make sense.

Unfortunately this is not tenable. For one thing, the paragraph in Ulpiani Rroular corresponding to that under review unmistakably belongs to tutela legitima. It reads: legitima tutela capitis deminutione amittitur, "tutela legitima is lost by capitis deminutio." ULPIANI Regular 11.9. We need not go into the precise relationship between ULPIANI Regulae and Gaius's Instrtutes. Unquestionably the former work (which prevalent opinion assigns to the first half of the fourth century A.D.) uses either the latter or a precursor of the latter or a revised edition of the latter. The way it understands the paragraph in question is of considerable weight. (It is, of course, simpler and more direct; nothing is said about agnation or cognation, nothing about civil law transactions and natural rights. We are offered a straightforward statement of the effect of capitis deminutio on tutela legitima. The qualification minima is missing, as in the Institutes.) Equally, in the INstitures of Justinian, principally relying on Gaius's exposition, the paragraph forms the close of the title De legitima adgnatorum tutela (1.15.3) while the excursus De capitis minutione occupies title 1.16. (I shall presently say something about the modifications 1.15.3 shows compared with GaIUs 1.158.) For another thing, if we treated the paragraph here inspected as opening the excursus on capitis deminutio, the omission of minima would be far more serious. In the opening sentence of an ex professo account, Gaius could not expect the reservation to be supplied by the reader. If this paragraph opened the law regarding capitis deminutio, he would really be representing the rights based on cognation as untouched even by capitis deminutio media or maxima. Of such nonsense he cannot possibly be guilty.

66 Compare infra, pp. $31 \mathrm{f}$.

62 The very notion of amittere tutelam, "losing the guardianship," which occurs in Ulpiani Regulae supra $n$. 65 , is an anachronism in the era of the composition of that book. UlpiaNI Regulae 11.9 concerns tutela legitima; even this is a burden by the fourth century. In 11.7 amittere is used in connection with tutela testamentaria. Three more texts are to be added: GaIus 1.182 , which if it does not exclusively contemplate tutela testamentaria at least includes it. Diass 4.5.7 pr., Paul XI ad edictum, where 
back of his mind a passage like that from Sabinus which is adduced by Gellius: "Our forefathers held that a man's obligations were in this order - first to his ward, then to his guest, then to his client, next to his blood relation, finally to his relation by marriage." 68

8. Justinian's Institutes on Agnates and Cognates in Connection with Statutory Tutorship. - Institutes 1.15 .3 more or less copies Gaius 1.158. I put the deviations in brackets. ${ }^{69}$ Sed agnationis quidem ius [omnibus modis] capitis deminutione [plerumque] perimitur. [nam adgnatio iuris est nomen.] cognationis vero ius non [omnibus modis] commutatur, quia civilis ratio civilia quidem iura corrumpere potest, naturalia vero non [utique].

Four points are noteworthy. First, Justinian inserts an explanation of the vulnerability of agnation by capitis deminutio: agnation is "a name of law," "a mere title of law." It will be remembered that he makes use of the notion in Institutes 3.1.11, probably drawing on the Res Cottidianae, and that he would also have found it in Gaius 3.21. Ferrini thinks that the explanation is a gloss that got into Gaius 1.158 prior to Justinian: quite possible.70

Secondly, whereas according to Gaius 1.158 agnation is always destroyed by capitis deminutio minima, Justinian puts plerumque, "generally." This is necessitated by postclassical and Justinianian reforms. ${ }^{71}$

Thirdly, he improves Gaius's presentation by making it quite clear that even cognation does not survive capitis deminutio maxima or media. Whereas Gaius 1.158 says that "agnation, though not cognation, is destroyed by capitis deminutio" (leaving it to the reader to supply minima), Justinian says that "agnation, though not cognation, is destroyed - in general - by all modes of capitis deminutio": by all modes, that is to say, even by minima. Moro-

the object of amittere is all classes of guardianship (but the verb is strangely used, signifying "to effect loss," as in 4.5.6, Ulpian LI ad Sabinum, which, in the Dionst, comes immediately before). Diozst 26.4.2, Ulpian XXXVII ad Sabinum, which concerns tutela legitima, not yet too bad in Sabinus's time.

68 5.13.5, quoting Sabinus III iuris civilis: in officiis apud maiores ita observandum est, primum tutelae, deinde hospiti, deinde clienti, tum cognato, postea adfini.

I ought to add that, should the Veronese palimpsest have the correct reading, quaedam instead of quidem, Gaius would be more complicated: "some civil law rights can be extinguished by a civil law reason." Some only - so there are even civil law rights defying the civil law, Kniep maintains (Gay Institutionum Commentarius Primus 67 [1911]) that Gaius means just this. Unfortunately he does not say what particular rights might be in point. Still, an interpretation on this basis is just possible: Gaius might, for example, be alluding to the argument he advances in 3.194-that a statute cannot turn a nonmanifest thief into a manifest one (see infra, pp. 26ff). It would be queer, however, to look upon this as a case of indestructibility of "civil law rights." Moreover, "some" makes to many inviolate. Again, it is not like Gaius to bring in a major qualification in such an offhandish, distracting fashion. Finally, the sentence, if taken in this way, would be rather inelegant. I incline to accept the orthodox emendation quidem. It is quidem which we find in INSTITUTES 1.15.3, which text now falls to be examined.

69 As far as quidem is concerned, see my comments supra n. 68.

70 See supra n. 48.

${ }^{71}$ See, e.g., Institutrs 3.5 pr. 
over, as in Gaius (and no doubt in the Res Cottidianae), there follows an excursus on capitis deminutio (Institutes 1.16), and here a special paragraph (1.16.6) is devoted to the distinction between the effect on the right of cognation of capitis deminutio minima and the other kinds of capitis deminutio. The paragraph begins by expressly restricting the survival of cognation to minima; it goes on to note and illustrate its extinction by maxima and ends by noting its extinction by media. ${ }^{72}$

Fourthly (and most importantly for us), Justinian does realize that the slogan of the indestructibility of natural rights exaggerates. Instead of proclaiming, with Gaius, that a civil law transaction cannot annihilate them, he says that it cannot annihilate them utique, "simply," "without ado," "totally"I shall not attempt to decide between the various nuances.

The special paragraph contrasting minima with the other kinds (1.16.6) shows, incidentally, a curious wording in its first portion: "As regards the statement above, that cognation survives capitis deminutio, this applies to minima only." The curious thing is that, in Justinian's exposition, "the statement above" (1.15.3) is no longer so careless as its source, Gaius 1.158. It already, by means of a twofold insertion of omnibus modis, "by all modes," as well as the reservation utique, "simply," corrects the slipshod original (which took the restriction to minima for granted). It is not true that it says that cognation survives capitis deminutio, period. So why does 1.16 .6 represent it as saying that? This paragraph, according to Ferrini, comes from the Res Cottidianae, ${ }^{73}$ and herein may lie the explanation. In the Res Cottidianae, we may suppose, Gaius 1.158 was still left unaltered; there were not yet, as in Institutes 1.15.3, the qualifications omnibus modis and utique. At that stage, "the statement above" was still carelessly wide, and what is 1.16 .6 in Justinian was added to put it right. The rectifications in $\mathbf{1 . 1 5 . 3}$ are attributable to Justinian himself, desirous to have the law outlined in an accurate manner from the outset; only he did not trouble to adjust the first portion of 1.16.6.74

No reason to overrate Justinian's analytical powers. The terms cognatio, "blood relationship," and ius cognationis, "the right of blood relationship," are still employed indiscriminately. There is still no precise separation be-

12 Quod autem dictum est manere cognationis ius et post capitis deminutionem, hoc ita est, si minima capitis deminutio interveniat: manet enim cognatio. nam si maxima capitis deminutio incurrat, ius quoque cognationis perit, ut puta servitute alicuius cognati, et ne quidem, si manumissus fuerit, recipit cognationem. sed et si in insulam deportatus quis sit, cognatio solvitur.

73 Ferrini, 2 Opere 344 [13 Bullettino 135].

74 Support for my suggestion is furnished by the two awkward successive ablatives omnibus modis capitis deminutione, "by all modes by capitis deminutio," in 1.15.3. That is not the style of the Res Cottidianae; it is the kind of thing resulting from an interpolation in the course of codification. 
tween the factual and legal position. ${ }^{75}$ After all, in Institutes 3.1.11, we have seen, the commonplace about natural rights occurs (is taken over, it would appear, from the Res Cottidianae) without the qualifying utique. Its addition in Institutes 1.15 .3 is surely due to the existence of 1.16 .6 , dwelling on the destruction of cognation by capitis deminutio maxima or media, and reflected in the insertion of omnibus modis in 1.15.3. With the legal result of capitis deminutio maxima and media highlighted in such a degree, it is not surprising that, on this occasion, the defectiveness of the commonplace obtrudes itself, can no longer be overlooked.

9. Gaius on Natural Obligations.-Digest 4.5.8, Gaius IV ad edictum provinciale, lays down that "those obligations the fulfillment of which is considered to be of a natural kind obviously do not end by capitis deminutio, since a civil law reason cannot destroy natural rights." It follows, we are told, that the action for restoration of a dowry, being equitable, conceived in bonum et aequum, survives capitis. deminutio. ${ }^{76}$

The following brief fragment, 4.5.9, Paul XI ad edictum, syntactically part of 4.5.8, adds "so that when the time comes the emancipated woman may sue," ut quandoque emancipata agat.

The jurists have in mind capitis deminutio minima only. The omission of the adjective is no problem: the edict they are commenting on ${ }^{77}$ applied only to this type. ${ }^{78}$ Hence the restriction is taken for granted.

The obligation referred to in the first part of 4.5 .8 may be naturales obligationes in a technical sense; this is indeed the prevalent view. On this basis, however, one would expect the topic to be capitis deminutio minima of the debtor, whereas the example of actio de dote envisages capitis deminutio minima of the creditor, the woman. Still, the technical sense of naturalis obligatio is so different in different periods (and maybe with different writers of the same period) that we should not be too surprised. On the other hand, there is the possibility that the very elaborate phrase obligationes quae naturalem

75 I also in this paper am lax in my usage and, for the sake of brevity, sometimes speak of "cognation" where I mean the rights. But I can afford it because I know, or trust, my readers will make the requisite adjustments.

76 Eas obligationes, quae naturalem praestationem habere intelleguntur, palam est capitis deminutione non perire, quia civilis ratio naturalia iura corrumpere non potest; itaque de dote actio, quia in bonum et aequum concepta est, nihilo minus durat etiam post capitis deminutionem. Beseler, 5 BeItrn̈or 17, branding ratio as postclassical, brackets the relevant bit from quia to potest, "since a civil law reason cannot destroy natural law rights." This is unwarranted; cf. supra, p. 13, on Galus 1.158 , and infra, p. 34, on Droest 7.5.2.1, Gaius VII ad edictum provinciale. In Romanistiche Studien, 8 TIJDschrifT VoOR Rechtsoeschiedenis 321 (1928), he reconstructs the text in too imaginative a fashion.

77 For the original context see Lenel, op. cit. supra note 64, at 197, 986.

78 See Digest 4.5.2 pr., Ulpian $X I I$ ad edictum. As for the wording of the Edict, see

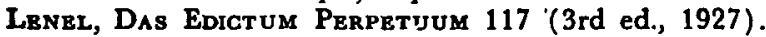


praestationem habere intelleguntur is not synonymous with naturales obligationes; and that it means obligations to be performed to a person defined by his natural position, irrespective of agnatic or even cognatic relationship. That would clearly include an obligation to be performed to a wife irrespective of a capitis deminutio she may have undergone. I shall presently adduce Digest 4.5.7pr. where, in an interpolated section, naturaliter designari does denote "to be defined by one's natural relationship"-though, to be sure, that text speaks of cognates, not of husband and wife.

At any rate, the resistance to capitis deminutio minima of obligations with a naturalis praestatio is explained by means of the slogan we know from Gaius 1.158 (and Institutes 1.15.3), except that it is shortened: we are spared the positive part, that a civil law transaction can extinguish civil law rights, and are given only the really significant negative one, "it cannot extinguish natural rights." I need not repeat the objections to this doctrine.

It has been alleged that these words are interpolated by the compilers. ${ }^{79}$ This is difficult to accept; it would be too much of a coincidence for a bit from one work of Gaius, the Institutes, to be stuck into an extract from another, his commentary on the provincial edict. Surely he resorted to the commonplace in the latter as well as the former; and quite likely it is because the compilers found it there that they used this piece from Gaius instead of contenting themselves with Paul, who supplies 4.5.7 and 4.5.9. The latter is so precisely on the topic of 4.5 .8 as to be introducible as, syntactically, a subsidiary clause of this fragment. It does look as if the compilers had had a special reason for preferring 4.5.8 to what was in Paul-that reason being the slogan.

Less immediately unconvincing is the proposition that what now surrounds this slogan in 4.5.8 is spurious. In the classical version, there may have been no talk of dowry. (If there was, the action must have been called rei uxoriae. Justinian commonly prefers de dote.) Indeed, there may have been no talk of "natural performance." Siber, for instance, holds that the slogan was attached to a distinction between ius agnationis and ius cognationis, just as in Gaius 1.158.80 (It is futile to speculate whether, if he is right, Gaius here associated the slogan with bonorum possessio only or also, stupidly, with tutela.) To Siber's own arguments should be added this, that in classical writings the concept of the indestructibility of natural rights may well have been confined

79 E.g., by Burdese, La nozione classica di "Naturalis obligatio" 113f. (1955).

80 Siber, Naturalis Obligatio, Gedenkschrift für Mrtreis 16 (1925). This work of Siber's is so well argued that on occasion initial rejection has been followed by conversion: contrast Albertario's review in 3 Studi Di Diritro Romano 55ff. (1936) [102 Arghivio GruRnoico 230ff. (1929)] with his article L.e critica del fr. $8 \mathrm{D}$. De capite minutis IV, 5, 4 Studia et Documenta Historiae et Juris 529ff. (1938). 
to succession, tutorship, and the like. It sounds rather pompous when applied to restoration of dowry, at least for classical law, where this is primarily a commercial affair; in Justinian's eyes it is indeed far more. It is demonstrable that Gaius did not think of extending the slogan to partnership. This is described by him as belonging to the ius gentium and therefore a universal phenomenon by natural reason; ${ }^{81}$ yet it is dissolved if a partner incurs capitis deminutio minima since, he says, "by civil law reason capitis deminutio is equated to death."82 However, there is no need for me to come to a decision about the original context of 4.5.8. I shall leave this question open, as also countless others arising out of this puzzling text.

Let me just note four points, though even these are not relevant to my main thesis. First, 4.5.9 may well be concerned with emancipation of a wife by her paterfamilias while she is married. The result would be that, should it come to divorce, she herself would sue for the dowry, instead of the paterfamilias with her merely in a supporting role (adiuncta fliae persona). My translation proceeds from this case. Other cases, however, are conceivable; for example, emancipation between divorce and litis contestatio-if we proceed from this situation, it would be better to translate "so that henceforth (in future) the emancipated woman may sue."83

Secondly, if the ending of 4.5.8 contemplates such situations, the formulation is curious. The action, we learn, durat, "remains," "goes on," after capitis deminutio. What happens is that as a result of capitis deminutio, the woman, up to now merely entitled to support or frustrate the action of her paterfamilias (being adiuncta to him), is entitled to bring it alone, and indeed, she alone is entitled to bring it.

Thirdly, Digest 4.5.7pr., Paul XI ad edictum-same provenance as 4.5.9, capitis deminutio minima - in its first half states that, except for tutela legitima, guardianship is not affected by capitis deminutio minima; and that tutela

81 Gasus 3.153f: iuris gentium est, itaque inter omnes homines naturali ratione consistit.

82 Quia civili ratione capitis deminutio morti coaequatur.

83 Droest 24.3.22.5, Ulpian XXXIII ad edictum. The decision that the paterfamilias in this case cannot bring the action is certainly correct. But the text as it stands pairs it off with the decision that he cannot bring the action if the daughter, having at first consented to it, changes her mind before litis contestatio: both decisions are represented as following from the rule that it is at the moment of litis contestatio that her consent is required. As a matter of fact, only the decision concerning her change of mind follows from this rule. We have the choice between two solutions. Either Ulpian discussed emancipation separately from change of mind, and the compilers, in order to abbreviate, threw the two cases together, inserting vel etiam si emancipata sit into the paragraph about change of mind. Or secundum haec, describing the two decisions as both of them consequences of the rule, should be excised: Ulpian would have made a fresh start with si filia. Beseler, 3 Beiträge zur Kritik der römischen Rechtsquellen 154ff. (1913), comdemns secundum hoc or haec in general. Whether right or wrong in this, he goes too far, $p$. 159, when he simply dismisses everything in Diogst 24.3.22.5 from secundum haec as "postclassical illustration." 
legitima, deriving from the XII Tables, is affected on the same ground as the agnatic succession of that statute, unde legitimi in the praetor's edict. (The present text is somewhat doctored. I am summarizing what Paul seems to have said.) The muddleheaded principle of the indestructibility of natural rights does not figure: no doubt that is why the compilers, 4.5.8, had to get it from Gaius. Nor do we find any allusion to ius cognationis in connection with guardianship, Gaius's particular blunder. Paul's comparison of the two cases of tutela legitima and unde legitimi is perfectly sound; it may well have been a traditional way, among the great classics, of presenting the matter in a survey of capitis deminutio minima.

The second half, ex novis and so on, is due to the compilers. ${ }^{84} \mathrm{We}$ are informed that new legislation frames the destination of both succession and guardianship in such a manner that "the persons are defined by their natural position," ut personae naturaliter designentur. As illustration the compilers mention the senatusconsults (Tertullianum and Orfitianum) establishing succession between mother and child. In respect of guardianship, they are probably thinking of laws like C. 5.30.4, by Anastasius, A.D. 498, and 6.58.15.4, by Justinian himself, A.D. 534. The latter ordains: "but those persons whom on the strength of the right of blood relationship we have transferred to the legitimate successions, we also subject to the burden of guardianship over one another."85 It might perhaps be argued that already Paul had in his discussion something about natural position or rights as opposed to civil law, which provided the stimulus for ex novis and so on. But there is no evidence to support this, and the remark of the compilers is, for them, so naheliegend, so easy to hit on, they needed no help.

Fourthly, what is the relation of the doctrine in Pomponius (Digest 50.17 .8 ) on the one hand and Gaius's Institutes (1.158, 3.21, 27, also Institutes 1.15.3) and the Res Cottidianae (represented in Institutes 3.1.11) on the other? Gaius may be indebted to Pomponius: this is perhaps still the current thinking. ${ }^{86}$ According to Honoré, the borrowing is more likely the other way round ${ }^{87}$ It is also, I suppose, arguable that they independently drew on a common source or floating material. That this is the relation between Gaius and Gellius I shall suggest below with regard to a theory concerning the discovery of stolen goods in the course of a ceremonious search. ${ }^{88}$ It would lead too far afield to go into

\footnotetext{
84 Wissenbagh, Emblemata Triboniant 21 (1736).

85 Quas autem personas ex iure cognationis in legitimas successiones transveximus, eas ot tutelae gravamini vicissim supponimus.

86 E.g., Krüoer, Geschichte der Quellen und Litteratur der Römischen Rechts 201 (2nd ed., 1912).

87 Honork, op. cit. supra note 41 , at $57 \mathrm{ff}$.

88 See infra, p. 29.
} 
the problem at length. Insofar as a passage from Paul quoted above ${ }^{89}$ can be regarded as alluding to the doctrine, the most plausible assumption is that he got it from Pomponius, whom he used a great deal.

10. Justinian's Institutes on Natural Laws.-Institutes 1.2.11 reads: "But natural laws, which are observed in all nations everywhere, being established by some divine providence, remain always firm and immutable; whereas those which each State establishes for itself are apt to be often changed, either by the tacit consensus of the people or by another statute subsequently passed."90

I shall not linger on this pronouncement which, in its present context at all events, is so general that what it aims at and within what limits cannot be determined. Nor, as Ferrini points out, ${ }^{91}$ is it possible to specify its provenance. It may be the work of Justinian (this is the prevalent view);92 it may be taken from a classical manual; it may be partly the former and partly the latter.

Curiously, Theophilus omits the mention of natural laws. He says: "But the laws of nations are administered in all nations, found from divine providence, whence they are firm and immutable. . ." What significance, if any, is to be attributed to this deviation I am unable to determine. Perhaps he was put off by the discrepancy between this use of the plural naturalia iura in the sense of "natural laws" and its normal use in the sense of "natural rights": it means "natural rights" in all the three remaining places in Justinian's Institutes. 93

There have been relatively few studies in depth of Justinian's ideas on law. The proclamation by which he published the Digest in 533 is preserved in Greek and Latin; only the latter states that while the divine is most perfect, there is nothing of eternal duration in human law. ${ }^{94}$ The Latin is generally more devotional than the Greek. 95

\footnotetext{
89 Dignst 38.6.4, II ad Sabinum; see supra, pp. 21 .

0 Sed naturalia quidem iura, quae apud omnes gentes peraeque servantur, divina quadam providentia constituta semper firma atque immutabilia permanent; ea vero, quae ipsa sibi quaeque civitas constituit, saepe mutari solent vel tacito consensu populi vel alia postea lege lata.

91 Frraint, 2 Optre 334 [13 Bullettino 126].

92 Maschi, La Concezione Naturalistica Del Diritto a Degli Istituti Giurmici Romani 221ff. (1937).

os 1.15.3 and 3.1.11, which I have discussed, as well as 1.11.12. Ferrini in his Latin rendering of Theophilus adheres too closely to the Latin text of INSTITUTEs 1.2.11 (INSTITUTIONU M etc. at 17). He puts constituta, "established" by providence. But heurethenta means "found," "discovered," possibly "devised," "invented" - not "established." He also retains peraeque, "everywhere," and quadam, "some" ("by some divine providence") though Theophilus drops both.

84 Constitutio Dedoken 18; Constitutio Tanta 18, CoDex 1.17.2.18.

95 See Ebrard, Das zeitliche Rangverhältnis der Konstitutionen De confirmatione Digestorum "Tanta" und "Dedoken," 40 Zeitschrift der SAvigny-Stiftung 135 (Roman section) (1919).

An assertion by Gaius as to the immutability of naturalis ratio in Droest 7.5.2.1, VII
} 


\section{INTERfERence WTth Facts ANd Concepts}

11. Paul on Possession.-Natural rights are one thing, facts another: the latter, we may agree, the law is powerless to overturn. But what is a fact? In the area of this inquiry, impossible laws, the question poses itself in several ways.

One of them is illustrated by a text on possession, Digest 41.2.1.4, Paul LIV ad edictum. A husband yields possession of an object (probably land, in Paul) to his wife, with intent to make her a present: most authorities, we learn, hold that she does now possess, quoniam res facti infirmari iure civili non potest, "since a point of fact cannot be invalidated by the civil law."

I shall not inquire whether Paul is primarily thinking of interdict possession $^{96}$ or usucapion possession (in the sense that, if the gift were confirmed by the husband's death, the period she had held the object would count for her). His point is that the ius civile, more especially the rule excluding gifts between spouses, cannot alter facts, and the wife's possession is a fact. Needless to say, he is not implying that the ius naturale or gentium could do what the ius civile cannot. It so happens that the difficulty of the case is created by the ius civile, hence the reference to it. Indeed, for the Romans, the ius naturale is so essentially in line with the real world that the statement that it cannot interfere with a fact would be superfluous, even queer.

What about the minority who, we are given to understand, do not regard the wife as in possession? They would hardly claim that the law, or the civil law, can alter facts; rather that possession is not a mere fact or that, though it is, the wife's holding does not amount to it.

Hägerström declares the reason quoniam ... interpolated. ${ }^{97}$ Every classical jurist, he says, knew that the ius civile did determine whether or not a man possessed in the legal sense: a slave, for example, who withheld an object from his master did not possess. This argument, however, though not devoid of force, is not fully conclusive. The classics often support a decision by a finesounding principle which does not fit without qualification. In the field of possession in particular, inexactitudes of this kind abound.

Some passages which proclaim the unalterability of facts are concerned, not with the law as such, but with private transactions. When Celsus says that "that which is ruled out by the nature of things, rerum natura, can be established by no lex," the context-both in his original work and in

ad edictum provinciale, I shall consider below, pp. 33ff., in connection with a different series of texts.

o6 So, e.g., Kaser, Eigentum und Besitz im Xlteren Römischen Recht 356 ff. (2nd ed., 1956), with strong arguments.

97 Hägerstrom, 1 Der römtsche Obliontionsbegrifp 197f., 206. 
the Digest-leaves no doubt that the reference is to a testamentary disposition requesting the impossible 98 Another paragraph from the same book of Celsus's work, which in the Digest directly precedes this one, was quoted above: contradictory dispositions in a will are void. Labeo and Javolenus adopt a decision by Ofilius rejecting a legacy of "a hundred pecks of wheat each of which is to weigh a hundred pounds," since such wheat does not exist, is not in rerum natura.99 Africanus discusses a legacy of "the ten I have in my chest" when in reality there are only five. A claim for more than five, he explains, would not be in accordance with reason, ratio, since as to the missing five the legacy may be said to refer to something not in existence, not in rerum natura. ${ }^{100}$ Pomponius and Gaius note that you may bequeath an object which, though not yet in rerum natura, is expected to come into existence -fruits, for example, or the offspring of a slave.101 It is to this complex that Celsus's utterance belongs. ${ }^{102}$

But let us go on to an entirely different variety of the problem of what is a fact.

12. Gaius on Manifest Theft Extended.-According to Gaius, whereas the XII Tables imposed a twofold penalty on ordinary theft, they laid down that a manifest thief, a thief caught in flagranti, was to be delivered over into the hands of his victim. Further, if a man's house was searched for a stolen object in the presence of witnesses and the object was found, he had to pay a threefold penalty. And again, if a search of this kind was resisted, a more ceremonious search was to be resorted to; and should the object turn up now, the theft, the XII Tables prescribed, would be a manifest one-iubet id lex furtum manifestum esse, "the statute decrees this to be manifest theft." 103

Elsewhere I have tried to show that this account is trustworthy and that attempts to disprove it, though common in Romanistic literature, are misconceived. ${ }^{104}$ Many authorities, for instance, maintain that the XII Tables spoke of one search only, the ceremonious one. This is wrong, I think. I

98 Diogst 50.17.188.1, XVII digestorum. Vorat, op. cit. supra note 33, at 306, seems to think of a statute. So perhaps does already BAsilica 2.8.188, translating lex by nomos, and certainly the Gloss: no law will uphold a promise of something impossible.

99 Digest 33.6.7, Javolenus $I I$ ex posterioribus Labeonis.

100 Digest 30.108.10, Africanus $V$ quaestionum.

101 Drozst 30.24 pr., Pomponius $V$ ad Sabinum; Galus 2.203; Instrtutrs 2.20.7; Gai Epitome 2.5.3.

102 Not surprisingly, the idea recurs in other branches of the law. Compare, e.g., Digest 50.17.31, Ulpian XLII ad Sabinum, from a section on pacts and stipulations in sale. Also from sale comes Digest 18.4.1, Pomponius $I X$ ad Sabinum, where sale of the inheritance of a living or nonexistent person is declared a nullity because the object is not in rerum natura. On a judge's order or a judgment for the impossible, Droest 49.8.3, Paul XVI responsorum, see supra, pp. 4f.

103 Gaivs 3.183ff. See Levy, op. cit. supra note 33, at 9 ff.

104 Daube, Studies in Bibligal Law 259f. (1947). 
would emphasize, however, that the argument I am about to develop is not fundamentally affected, will stand, in the main, even if modern corrections of Gaius may be deemed plausible. For this reason I shall not make constant reference to slight qualifications of my thesis which acceptance of these conjectures would entail.

To begin with, then, let me quote Gaius's comment on the code's regulation: "Because of the fact that the statute decrees the theft in that case (the ceremonious search) to be manifest, there are some who write that theft becomes manifest either by statute or by nature: by statute the very theft we are discussing (where the object is found by the ceremonious search), by nature that which we expounded above (where the thief is caught in flagranti). But the better view is that only theft manifest by nature is to be regarded as manifest. For a statute cannot bring it about that he who is not a manifest thief should be a manifest one - no more than that he who is not a thief should be a thief, and that he who is not an adulterer or homicide should be an adulterer or homicide. That indeed a statute can bring about that a man should be liable to a penalty as if he had committed theft or adultery or homicide even though he has committed none of these."105

The XII Tables, it will have been realized, meted out the same harsh treatment to a thief caught in flagranti and to him with whom, after he had opposed a simple search with witnesses, the object was finally discovered in the procedure lance et licio, "with loincloth and platter."106 However, they dealt with the latter case in a somewhat indirect way. Instead of directly stating the punishment, instead of saying that a man convicted by this procedure should be delivered (as was a manifest thief) into the power of plaintiff, they achieved this effect by simply subsuming the case under the basic category, by simply declaring it to be manifest theft. Doubtless, the phrasing was furtum manifestum esto, "it shall be manifest theft," just as in other early instances of

- 105 Garus 3.194: Propter hoc tamen quod lex ex ea causa manifestum furtum esse iubet, sunt qui scribunt furtum manifestum fieri aut lege aut natura: lege id ipsum de quo loquimur, natura illud de quo superius exposuimus. Sed verius est natura tantum manifestum furtum intellegi. Neque enim lex facere potest ut qui manifestus fur non sit manifestus sit, non magis quam qui omnino fur non sit fur sit, et qui adulter aut homicida non sit adulter vel homicida sit. At illud sane lex facere potest ut proinde aliquis poena teneatur atque si furtum vel adulterium vel homicidium admisisset, quamvis nihil eorum admiserit. The Veronese manuscript reads sunt qui scribunt furtum manifestum aut lege aut natura. At a pinch this could be left unemended. Of the insertions suggested $I$ prefer Kniep's insertion of fieri after manifestum (GAI Instrtutionum Commentarius Tertus 56 [1917]), to the more popular intellegi after lege; and I do not do so only because the Veronese MS has furtum $m f$ which, he ingeniously observes, might stand for furtum manifestum fieri, not simply for furtum manifestum. Anyhow he should not be represented as inserting the fieri after lege - a slip committed by Davm, GaI Institurones 113 (Editio Minor, 1964).

106 Thus Garus 3.193, but other understandings of the phrase are defensible. 
indirect regulation: a statute ascribed to Numa enjoined that if a man killed another with malice aforethought, parricidas esto, "he shall be a murderer" or "it shall be murder." 107 In a sense, another provision from the section on theft in the XII Tables themselves is comparable: if you kill a thief who comes by night, iure caesus esto, "he shall be lawfully slain."108

I shall not go into these parallels but concentrate on the paragraph pronouncing it to be manifest theft if the object comes to light in the course of the ceremonious search. At that time, the resistance from the outset and all that followed from it made the latter case a desperate matter of life and death, quite close to the former. It was quite close also in this, that, in the circumstances, there could not be a shadow of doubt as to the accused's guilt. The code, therefore, in decreeing furtum manifestum esto, did no violence to the facts, gave furtum manifestum only a slightly extended meaning. Gradually, however, the search "with loincloth and platter" became obsolete. It had vanished, say, by the middle of the Republic, and we must not assume subsequent generations to be familiar with its original setting and significance. Actually, Gellius, a contemporary of Gaius, mentions the remark of a lawyer friend of his, that only if he had studied the laws of the Fauns and Aborigines - the mythical forerunners of the Romans-could he be expected to understand institutions of that sort. ${ }^{109}$ No wonder, therefore, that the jurists interested in the XII Tables found the formulation furtum manifestum esto, "it (the case where the object is found as a result of the ceremonious seanch) shall be manifest theft," puzzling. The problem what to make of it evidently antedates Gaius, who introduces one solution by "there are some who write."

Some hold, he says, that the statute adds to manifest theft natura-where a thief is caught in flagranti-a manifest theft lege-where an object is discovered by the ceremonious search. The starting point is that there is a given, "natural" manifest theft, namely, what appears as such to the ordinary man and in everyday language. The law, however, can create another: in law, an ass might be a horse. Whether, for the advocates of this doctrine, the species created by statute has to show a minimum of prima facie affinity with the genuine one, it is difficult to decide. Probably not. After all, it is precisely because, to them, the discovery by ceremonious search which the XII Tables subsume under manifest theft looks distinctly nonmanifest that they felt the need for an explanation, arriving at the doctrine in question. Moreover, we shall see presently that the same school of thought seems to have postulated a usufruct lege which had little to do with "natural" usufruct.

107 Festus (Paulus) 221.

108 XII Tablrs VIII, 12.

109 Gellius 16.10.7f. 
Gaius disagrees: there is only manifest theft natura, since the law has no power to turn a nonmanifest thief into a manifest one-or, for that matter, a nonthief into a thief, a nonadulterer into an adulterer, a nonhomicide into a homicide. The law can only make a man punishable as if he had committed theft, adultery or homicide though in fact he has not. Note a minor carelessness: at the end Gaius forgets about the very case he is analyzing, he forgets to mention, what should be the climax of his series of things the law can do, that the law can impose a penalty as if there had been furtum manifestum though in fact there has been only furtum nec manifestum.

The starting point, as for the other doctrine, is a given, "natural" manifest theft. Indeed, this is the only species: where the present doctrine parts company with the other is in that the possibility of adding a species by statute is denied. The statute is, of course, upheld, but reinterpreted as expressing a fiction, shorthand way. It does not, as one might be led to think at first sight, make the case where an object is found by ceremonious search into manifest theft. It merely lays down that the case-which remains different-should be treated as if it were the same. Even in law, an ass cannot be a horse: we can only transfer to it the rules relating to a horse as if it were one, too.

If we look for analogies to these two doctrines in the modern debate about legal personality it is, curiously, the one mentioned first, the one Gaius rejects, which comes nearest the Fiction theory, with its assumption of a "natural" personality and one created by the law, a "legal" one. True, the Fiction theory tends to see in the legal creation something of lesser standing. This element is foreign to the Roman doctrine which puts manifest theft natura and manifest theft lege on the same level; of course, the subject of personality calls forth very special emotions. The doctrine mentioned second, the one adopted by Gaius, is highly reminiscent of what goes by the name of Symbolist, Bracket, or Collectivist theory. According to the Symbolist theory, legal personality is nothing but a device to express in an expeditious, brief fashion complicated relations between natural persons, the only ones existing. There is no personality lege, created by the law: the law considers only the natural person; though, for the sake of efficient, compact description of intricate arrangements, it may speak as if there were another. It is interesting that fiction thus plays a part in the Symbolist theory. ${ }^{110}$ Certainly the nuance is not quite the same as in the Fiction theory. In a sense, indeed, there is more of a fiction: while the Fictionists do admit a legal personality though, com-

110 The very term Fiktion is used by Ihering in outlining his theory in 1 Grist DES Römischen Rechts 202 n. 99 (7th and 8th ed., 1924). Other words used are "technical instrument," technisches Intrument, vol. 2, pt. 2 [6th and 7th ed., 1923], p. 366f.; "device," 
pared with the natural person, it is fictitious, the Symobilsts deny any such thing; it is merely convenient sometimes to talk as if, say, a corporation were a person. The doctrine Gaius favors is strikingly similar. The only manifest theft, theft, adultery or homicide is that natura. There is no manifest theft, theft, adultery or homicide lege. When the law decrees of something else that it shall be any of these things, all that is meant is that the consequences shall be as if one of them-the "natural" crime-had been committed.

Which of the two doctrines is the older? I would suspect that it is that discarded by Gaius: there are two kinds of manifest theft, one natura and one lege. This doctrine keeps more loyally to the wording-and spirit-of the provision which, after all, does speak of manifest theft tout court, "it shall be manifest theft." The doctrine which Gaius prefers-the law cannot make its own kind of manifest theft; it only treats a different case as if it were manifest theft-is considerably more daring, independent. Even this, not surprisingly, contains no trace of the modern, historical view here taken as to the origin of the difficulty felt about the statute, that it declared the case in question manifest theft because, at that time, it virtually was whereas later it lost that character.

The doctrine approved by Gaius, however, is no more his product than that he rejects. It plainly underlies the exposition of the matter in Gellius: "Those thefts which were detected by loincloth and platter the decemvirs punished as if they were manifest." 111 It may be taken that neither did Gellius use Gaius nor Gaius Gellius, but I cannot here enlarge on the point. Nor can I go into the question whether they drew on the same source or different ones. Gellius often relied on information by word of mouth. It is clear that; around the middle of the second century A.D., this was the fashionable doctrine. My hunch is that its author is Labeo; it would fit in with his role in the classification of various modes of theft to which I shall come in a moment. ${ }^{112}$

13. Gaius on Theft, Adultery and Homicide Extended.-It is worthwhile to look at the parallels Gaius adduces: a statute can turn a nonmanifest thief into a manifest one no more than (1) one who is not a thief at all into a thief, (2) a nonadulterer into an adulterer or (3) a nonkiller into a killer. None of the three are chosen at random. In all three cases a problem much like that created by "it shall be manifest theft" did in fact exist.

Kunstgriff, "artifices," Kunstprodukte, "mechanisms," Mechanismen (6th and 7th ed. 1924), vol. 3, p. 224f.; and "appearance," Schein, in the main discussion, vol. 3, pp. 356ff. I failed to take account of this in Studies In Biblical LAw, pp. 296, 301, where I represent Gaius as a Fictionist.

111 Gellius 11.18.3: ea quoque furta quae per lancem liciumque concepta essent proinde ac si manifesta forent vindicaverunt.

112 See infra, pp. $30 \mathrm{f}$. 
(1) The first parallel is the impossibility of decreeing a nonthief to be a thief. This refers back to a point Gaius discusses only a paragraph before, in the opening part of his section on theft. ${ }^{113}$

In the XII Tables we find theft accompanied by four distinguishing attributes: there is manifest theft, where the thief is caught in flagranti; nonmanifest theft, the ordinary case; theft taken hold of, conceptum, where a man's house is searched in the presence of witnesses and the object turns up; and theft inflicted, oblatum, where the man in whose house the object turns up was saddled with it by somebody else-the latter is liable to him. Servius, a late Republican jurist, in systematizing the law of theft, faithfully took the code as his guide. As Gaius tells us, he divided theft precisely into these four classes: manifest, nonmanifest, taken hold of, and inflicted. Sabinus accepted this classification, but Labeo demurred. He denied that taken hold of and inflicted were classes of theft on the same level as manifest and nonmanifest, his principal reason doubtless being that you could fall under these headings without being guilty of dolus: the man in whose house the object turns up might be innocent, and so might be the man who brought it to him, in which case one could not call them thieves. There were, Labeo argued, only the two classes, manifest theft and nonmanifest theft, whereas taken hold of and inflicted were merely actions connected with theft. (It might make a practical difference: for example, on the basis of Labeo's classification, with taken hold of and inflicted excluded from theft proper, an innocent person convicted under these heads would presumably not incur the infaming consequences imposed by the edict on one convicted of theft.) Gaius, though a Sabinian, openly sides with Labeo ("the better view") ;114 and, in his description of taken hold of and inflicted, emphasizes both that in these cases the person held accountable need not be a thief (he is liable quamvis fur non sit) and that it is a question of the law providing two special actions on top of theft in the full sense (nam propria actio constituta est with regard to taken hold of, nam propria constituta est actio with regard to inflicted). ${ }^{115}$

It is quite possible that Servius and Sabinus spoke of theft taken hold of and theft inflicted as theft lege, in contrast to theft natura. Whether they did so or not, the position taken up by Labeo and approved by Gaius is that the law cannot make a nonthief into a thief, though definitely it may sanction an action against anyone who is somehow tied up with theft. It is Labeo's role

113 GaIUs 3.183, $186 f$.

114 Gaius 3.183 at the end.

115 Garus 3.186f. That this emphasis is intentional, designed to justify Labeo's theory, follows from the little clause Gaius adds to his acceptance of that theory, 3.183: it is the better view, he says, "as will appear below"-namely, from the exposition of taken hold of and inflicted in $3.186 f$. 
in this controversy which makes me wonder whether he is not also responsible for the progressive line concerning "it shall be manifest theft."116 Anyhow, this is the background of the first parallel, non magis quam qui omnino fur non sit fur sit.

I fear I must add a footnote not very flattering to Gaius. By his time, at least the action furti oblati, "on the ground of theft inflicted"-though probably not yet furti concepti, "on the ground of theft taken hold of"-lay only if there was dolus; in fact, it lay only if defendant had quite deliberately got rid of the object to plaintiff in order that the latter should be incriminated rather than he himself. This means that, by now, only a thief could be convicted by this action, for whether or not he was the man who had first stolen the object, this knowing, treacherous palming off clearly involved contrectatio, that peculiar "illicit, nasty handling" which was the essence of the delict in classical law. Gaius, therefore, should not have taken over Labeo's view without modification. He certainly should not have said that this action was available irrespective of whether the accused was a thief.

This is of course only one of many instances in the Institutes where one has the impression that the author is in the main writing out a more ancient work, with an occasional reference to newer developments. ${ }^{117}$ In the present case, however, the impression becomes almost a certainty. The statement that the person held accountable under theft inflicted need not be a thief, true only in an earlier period, is made in the very same paragraph where the conflicting requirement of dolus, of more recent origin, is enunciated: "Theft inflicted is said to occur where the stolen object has been inflicted on you by somebody and has been taken hold of on your premises, at any rate if it was given you with the intention that it should be taken hold of on your premises rather than on those of the giver."118 This is really explicable only if we assume that the basic text is simply copied from an older source, copied, indeed, in an

116 See supra, p. 29.

117 See e.g., Daube [Book Review], Schulz, History of Roman Legal Science, in 38 JourNal of Roman Studies 114 f. (1948).

118 GaIUs 3.187: Oblatum furtum dicitur cum res furtiva tibi ab aliquo oblata sit caque apud te concepta sit, utique si ea mente date tibi fuerit ut apud te potius quam apud eum dederit conciperetur. I follow DE Zulueta, 1 The Institutes of GaIUs 215 (1946), in translating utique si by "at any rate if." The meaning is "though only if." In two more passages of the INstrTutes a rule is directly followed by this phrase, 2.76 and 2.78. They deal with the cases where you are in possession of my land and build on it, plant in it or sow it (2.76) and where you are in possession of a panel belonging to me and paint on it $(2.78)$. If I bring an action for recovery of my land or my panel but refuse to pay your expenses, you can defeat me by an exceptio-utique si, "at any rate if," "though only if," you were a possessor in good faith. Utique cum has the same force. It occurs once, in 3.96, where Gaius remarks that, except for the oath binding a freedman to render his patron certain services, we meet no oath which grounds an obligation-utique cum quaeritur de iure Romanorum, "though only so long as our study is the Roman law": he goes on to point out that in some foreign laws it is different. 
astonishingly mechanical way: the old-"even if he is not a thief"-remains untouched next to the new - "provided it was given you with intent." Of late a few scholars have become anxious lest Gaius may have been judged too harshly by the moderns; ${ }^{119}$ and one all-out attempt in particular has been made to raise him from the status of a second-rater commonly assigned to him. ${ }^{120}$ But no ingenuity of argument can bring it about ut qui classicus non sit classicus sit. Let me note that long before Justinian, dolus was-required in the case of theft taken hold of, conceptum, as well as theft inflicted, oblatum; and both were absorbed by ordinary, nonmanifest theft. ${ }^{121}$

(2) The second parallel is that a statute cannot change a nonadulterer into an adulterer. This, I guess, also comes from the older source. Under the lex Julia de adulteriis of 18 B.C., quite a few cases not strictly adultery were dealt with pro adulterio, "as adultery" or "as if adultery," the guilty person was sentenced quasi adulter, "as adulterer" or "as if an adulterer," "under the heading of an adulterer." For example, a man knowingly marries a woman convicted of adultery; a husband fails to divorce his wife caught in flagranti; a spouse makes a profit from the other spouse's adultery. ${ }^{122}$ I have given alternative renderings, "as" and "as if," because the Latin pro and quasi are both ambiguous. The idea may be either that these crimes are punishable "as adultery," the criminal "as an adulterer," i.e., they are adultery, he is an adulterer, if you like adultery lege and adulterer lege; or that these crimes are punishable "as if adultery," the criminal "as if an adulterer," i.e., they are not adultery, he is not an adulterer, it is merely that we are to proceed as if we had to do with adultery and an adulterer.

Whether the statute itself spoke of pro adulterio and quasi adulter or whether these expressions are due to its early interpreters may be left open. (Very likely some such phrase did figure; it may, of course, have been pro adultero.) What matters is that the cases in question evidently presented the same jurisprudential difficulty as the subsumption by the XII Tables of a situation not "naturally" manifest theft under this offense. By contrast with the latter, antiquated provision, those of the lex Julia were of acute importance. We know, indeed, that this entire legislation evoked enormous interest among lawyers and was much analyzed. There is every reason to believe that the debate was in full swing in Labeo's lifetime. Here, then, is the setting of the second parallel, the refusal to recognize any but "natural" adultery.

119 de Zulueta, 2 The Institutes of Gaius $7 \mathrm{ff}$., does his best for him, which is too good.

120 HoNone, op. cit. supra, note 41.

121 Institutes 4.1.4.

122 Drozst 4.4.37.1, Tryphoninus III disputationum, pro adulterio; Diasst 48.5 .9 pr., Marcian II de adulteriis, 48.5.34.2, Marcien I de publicis iudiciis, quasi adulter and quasi adultera. 
(3) The third parallel-a nonkiller is not a killer-may well be Gaius's contribution. Surely it alludes to Hadrian's rescript which-perhaps more or less by way of reaffirmation-subjected attempted murder to the same penalties as the completed crime. The person guilty of attempt, the texts say, is to be sentenced pro homicida or ut homicida; either phrase is ambiguous and may mean equally "as killer" or "as if a killer." The rescript seems to have said pro homicida. Ulpian writes: "The words of the rescript-On the one hand he who has killed a man is normally acquitted, namely, if he did so without intent to kill, on the other hand he who has not killed but has tried to kill is sentenced pro homicida."123

14. Gaius on Usufruct Extended.-The doctrine favored by Gaius in his Institutes recurs in his commentary on the provincial edict, quite possibly the earlier of the two works. ${ }^{124} \mathrm{He}$ is discussing a senatusconsult of the end of the Republic or the early Empire-under Augustus or Tiberius-enabling a testator to leave what we call a quasi-usufruct, a right over perishable, consumable goods such as money, wine, oil: the legatee obtained ownership and by means of a cautio gave security for return, at the expiry of the quasiusufruct, of things of the same quality and quantity. This cautio was a modification of that traditional in ordinary usufruct, over a nonperishable object, by which return of that object was guaranteed.

From what Gaius says it is obvious that the senate used the indirect method of regulating the matter that we found in the case of "it shall be manifest theft," bringing the case to be dealt with under an established category. It did not just set out the detailed rules to apply to such a legacy (though some detailed rules, e.g., as to cautio, did figure in the senatusconsult). Nor did it term the right as we do, a quasi-usufruct. What it ordained was that the right resulting from the legacy was, or should be, a good usufruct.

That some such language was employed is confirmed by other texts. "The senate decreed," Ulpian tells us, "that a usufruct can be left over every kind of thing that is agreed to be in any person's patrimony."125 Similarly, in Institutes 2.4.2 we hear that "the senate decreed that also over those (perishable) things a usufruct could be created."126 The latter text is particularly

123 Collatio 1.6.2, Ulpian VII de officio proconsulis sub titulo sicariis et veneficis. In 1.6.4, which is comment on the rescript, we find ut homicida. Pro homicida also in Marcian's report of the rescript, DIGest 48.8.1.3, XIV institutionum. Ut homicida again in Collatio 1.7.1 [equals Pauli Sententiae 5.23.3], where the rescript is paraphrased but not expressly mentioned.

124 Dioest 7.5.2.1., VII ad edictum provinciale. My footnote on this text in STudies in Biblical Law, p. 313 , is very superficial.

125 Digest 7.5.1, Ulpian XVIII ad Sabinum; essentially the translation of Monro, 2 The Digest of Justinian 44 (1909). For an alternative interpretation see infra note 131. The Latin is Senatus censuit, ut omnium rerum, quas in cuiusque patrimonio esse constaret usus fructus legari possit.

126 Senatus censuit posse etiam earum rerum usum fructum constitui. 
strong evidence since, as we shall see, ${ }^{127}$ the author would much rather have it different, would much prefer the senate to have expressed itself more cautiously.

This is how Digest 7.5.2.1 runs: "By this senatusconsult it is not brought about that there is a usufruct over money properly - for natural reason could not be overturned by the authority of the senate-but with the introduction of a remedy it begins to be treated as if a usufruct." 128

One can sympathize with the bogglers at the senatusconsult, the new case having very little to do with the old, at least as far as its legal-technical structure is concerned. The affinity is chiefly in the socioeconomic function. As is well known, the senate was faced by bequests of a usufruct bonorum or omnium bonorum, over a man's goods or entire goods, which would ordinarily include perishables as well as a house, slaves, or the like. In Cicero's Pro Caecina, delivered in 69 B.C., a man makes his son heir, leaving his wife a usufruct over all his property for life to be exercised jointly with the son. ${ }^{129}$ Presumably, as the senatusconsult was not yet in existence, this was valid only in respect of the nonperishable objects in the estate. In the Topica, written in 44 B.C., we find the following illustration of an argument "from the contrary": "A woman whose husband has bequeathed her a usufruct over his goods and has left full wine and oil cellars must not believe that these fall under her right. For use, not consumption, has been bequeathed (usus enim, non abusus, legatus est) - these are contrary to one another." 130 This passage surely reflects an interesting point in the development culminating in the senatusconsult-namely, that point when pressure for allowing a usufruct over an entire estate to cover the perishables in it was mounting, but still resisted. In the end the senate did validate such gifts, ${ }^{131}$ and soon, if not at once, you could create a usufruct over perishables separately, i.e., even apart from a usufruct over your entire assets. In juristic writings, incidentally, the noun

\footnotetext{
127 See infra, pp. $39 f$.

128 Quo senatus consulto non id effectum est ut pecuniae usus fructus proprie esset-nec enim naturalis ratio auctoritate senatus commutari potuit-sed remedio introducto coepit quiasi usus fructus haberi. In ROMANISTIBahe STUDIEN 320, Beseler changed naturalis ratio into ratio iuris; later, in 5 BEITRÄGe 22, he crossed out the entire clause nec enimpotuit, "for natural reason could not be overturned by the authority of the senate." None of this is plausible: cf. supra, p. 13, on Gaius 1.158, and p. 19, on Droest 4.5.8, Gaius IV ad edictum provinciale. A valuable discussion of Digest 7.5.2.1 as well as Institutes 2.4 .2 is supplied by Grosso, Sul Quasi Usufrutto, 43 Bulletrino Dell' Istituto DI DiRItTo Romano 248ff. (1935).

120 Ciceroo, Pro Cabcina 4.11.

130 Gicrro, Topics 3.17: Non debet mulier cui vir bonorum suorum usum fructum legavit, cellis vinariis ot oleariis plenis relictis, putare id ad se pertinere; usus enim, non abusus, legatus est - ea sunt inter se contratia.

131 As the original decree contemplated legacy of the usufruct over a whole inheritance, it is conceivable that in Digest 7.5.1, quoted above, there is preserved a reference to just this case. If so, we might translate: "The senate decreed that a usufruct can be left over all things of which it is established that they are in a person's estate," i.e., a usufruct omnium bonorum includes the perishables too.
} 
abusus occurs only in three postclassical insertions in Ulpian in the Digest, ${ }^{132}$ and one place in the postclassical Ulpiani Regulae; $;^{\mathbf{1 3 3}}$ in all four passages, indeed, as in Cicero's Topica, it denotes "consumption" in connection with usufruct. The classics clearly avoided the term because of its double meaning; it might signify "abuse."134

However, what was the true effect of giving the legatee ownership and imposing an obligation to return an equal amount? It was something very like an interest-free loan, ${ }^{\mathbf{1 3 5}}$ most rules and considerations of regular usufruct being utterly inapplicable. No wonder the senate's calling this a usufruct provoked jurisprudential comment. It should be recalled that regular usufruct itself was not all that old, so the literal meaning of the term would be close to the surface in any case. But apart from this, to describe the new institution as usufruct, especially once there could be a separate right over, say, 10,000 sesterces or 50 barrels of Falernian, not just as part of a usufruct over an entire inheritance, was an astounding extension of the term. With some exaggeration one might imagine a senatusconsult validating consensual conveyance by declaring it a good societas omnium bonorum ${ }^{\mathbf{1 3 6}}$ - with, indeed, quite different rules from societas. It is significant how much trouble the senate's method gives to a modern scholar like Levy, in a chapter where he is concerned to show that the classics did not mix up usufruct and ownership: "Regardless of the wording of the statute or a bequest, his [the beneficiary's] right in re was not ususfructus but proprietas."137

If we ask why, despite all this, the senate did assign the case in question to usufruct, the answer must make reference not only to the social and eco-

132 Dioest 7.5.5.1f., XVIII ad Sabinum; 7.8.12.1, XVII ad Sabinum; 12.2.11.2, XXII ad edictum; see Kübler, Exegetische und kritische Bemerkungen zu einigen Digestenstellen, 59 Zeitschrift der Saviony-StTftung 569f. (1939). The context in 7.8.12.1 is slightly different from that in the other texts, but even here it is right to excise abusus. A man who has a usus over land may take wood for daily purposes, apples and so on, water, non usque ad compendium sed ad usum, scilicet non usque ad abusum, "not to the extent of profit but of use, that is to say, not to the extent of consumption": the scilicet clause is an appendix both very inelegant and not really accurate. On 12.2.11.2 I shall say more below, pp. 411 .

193 Why all occurrences are associated with Ulpian is a puzzle.

134 Kübler, op. cit. supra note 132, denies that abusus in Cicero has anything to do with "consumption"; it simply means "abuse." But, for one thing, it is difficult to believe that there should be this discrepancy between . Cicero and all legal texts on exactly the same subject, and for another, no better setting for Cicero's illustration can be imagined than a stage on the way to recognition of usufruct over consumable goods. What may be admitted is that the opponents of the recognition made play with the pejorative potential of the word: that is why the classics dropped it, why it is confined to preclassical and postclassical vocabulary.

135 Buckland, A Textbook of Roman Law 271 (3rd ed. revised by Stein, 1963). 136 Where the partners become co-owners at the moment of the contract: Digest 17.2.1.1, Paul XXXII ad edictum, 17.2.2, Gaius X ad edictum provinciale.

137 Levy, West Roman Vuloar Law 35 (1951). The reference to "statute" is explained by the fact that Levy-no doubt rightly-regards the senatusconsult as supplementing a statute of Augustus. 
nomic closeness but also to the machinery for final settlement at the expiry of the term of enjoyment. I have already mentioned that in ordinary usufruct, over a nonperishable object, at the beginning of the term, the usufructuary by means of a cautio guaranteed return of the object at the end. This cautio was a characteristic and much analyzed element in usufruct. ${ }^{138}$ When the senate decided the time had come to recognize usufruct over perishables, it prescribed a modified cautio for this case-guaranteeing return of things of the same quantity and quality. The texts leave no doubt that this common machinery, the cautio, greatly contributed to the classification of the new case as usufruct. 139

From the first moment there must have been controversy as to the construction of the new institution. One party must have construed it as usufruct lege, which in this case might be the more satisfactory solution. It is relatively easy to think of a category lege, of usufruct lege, as greatly differing from the basic category, from ordinary, "natural" usufruct. After all, legal personality greatly differs from a human person. The line taken by Gaius-in reliance on earlier authority-is less appropriate to this case than to those inspected above. The arrangement in question, he holds, is considered as if a usufruct. But this is not really true. Except for the fact that it is upheld (but so are sale, traditio, marriage, and countless other dealings) and a very few specific features such as limitation to the lifetime of the beneficiary and, indeed, the cautio, the law accords it radically dissimilar treatment.

Gaius says that to make the new case usufruct would be contrary to naturalis ratio, "natural reason"; that is indeed why the lawgiver cannot do it. In the remarks on manifest theft and the like, we came across no reference to naturalis ratio. This may be accidental, but $I$ do not think so. What is and what is not manifest theft, who is and who is not a thief, an adulterer, a homicide-these appeared to be straight questions concerning the external world, and a lawgiver transferring the word would simply fly in the face of facts. What is and what is not a usufruct, I suspect, was felt to be a somewhat more complicated question, having regard not just to externals but to a legal category. For the classics, a sound legal category, like a fact, had its intrinsic, unshakable characteristics, ${ }^{140}$ and you could not arbitrarily transfer its name to a situation not showing these. Nevertheless, the blunder would be just a little less obvious than the misdescription of one fact by the name of another.

138 See the sections $U t$ usus fructus nomine caveatur and Usufructuarius quemadmodum caveat in Lenel, Das Edictum Perpetuum 368f. and 538f. (3rd ed., 1927).

139 Digest 7.5.2, Gaius VII ad edictum provinciale; 7.5.4, Paul I ad Neratium; INSTITUTES 2.4.2.

140 See Levy, op. cit. supra note 33, at 8 ff. He does not, however, make my distinction. Compare also MASchI, op. cit. supra note 92 , at 258 . But see also infra, p. 43 and p. 49 note $186 \mathrm{a}$, on "manifest theft." 
It would be a blunder as to the onder of things rather than the things themselves - a violation of naturalis ratio.

Let me add that the thrust of the statement is rather different also from that in the texts considered earlier, which insist on the unabolishability of naturalia iura, "natural rights." With the exception of Institutes 1.2.11, those texts are all concerned with rights grounded in family ties. Their object is less the preservation of clarity about the various legal categories than the assertion of the unlosability of certain positions in the family; they are more ethical. Neither could Digest 7.5.2.1 be reformulated with the help of the term iura naturalia nor those texts with the help of naturalis ratio: the direction of thought would be radically falsified.

The final portion of 7.5.2.1, sed remedio introducto coepit quasi usus fructus haberi, has been attacked by Segré. ${ }^{141}$ He proceeds from the orthodox interpretation to which, I must now confess, my translation does not conform. The current interpretation is that Gaius is here working with the notion of a quasi-usufruct: "But with the introduction of a remedy the arrangement came to be held a quasi-usufruct." 142 Segré feels, not unreasonably, that this notion was not yet reached in classical law. Moreover, he argues, the clause is illogical; as a logical conclusion Gaius should have stated, not that as a result of the remedy a quasi-usufruct came about, but that in this way effects analogous to usufruct were achieved.

However, this is precisely what Gaius does state. ${ }^{143}$ Only we must not, in rendering the passage, let ourselves be misled by Institutes 2.4 .2 , where quasiusufruct does figure, or very nearly. ${ }^{144}$ The proper rendering is: "But with the introduction of a remedy, the arrangement begins to be considered as if a usufruct" - exactly what Segre wants Gaius to say. The notion of a quasiusufruct is not yet there. The doctrine corresponds to the Gaian attitude in all the cases already presented. It is carried a step or two further in Institutes 2.4.2 which, we shall see, comes from the Res Cottidianae. It would be rash in the extreme to dispute the authenticity of the sed clause.

141 Segre, Sul Deposito Irregolare in Diritto Romano, 19 Bullettino DelL'Istrtuto dr Dirtto Romano 197 (1907).

142 In this sense MONRO op. cit. supra note 125, at 44 : "there came to be something analogous to usufruct."

143 As pointed out above, pp. 34f., it is not even strictly true that the effects - the legaltechnical ones - were analogous to usufruct. But within the framework of Gaius's doctrine, it is indeed the logical upshot.

144 A fortiori we must not be influenced by Diogst 43.18.1.6, Ulpian $L X X$ ad edictum. The meaning of et quasi usum fructum sive usum quendam eius is quite obscure and in any case the text is spurious. See Beseler, Beitrïge, vol. 1 (1910), 106, Perozzi, 1 IstTtuziont di Dirutto Romano 789 (2nd ed., 1928), Kaser, 1 Das Römisohz Privatrecht 380 (1955). 
Segré has found a large following. ${ }^{145}$ But even those who oppose him do so on the wrong basis, trying to prove that the concept quasi-usufruct could be classical. Bonfante cites a letter by the younger Pliny ${ }^{146}$ where Pliny, enlarging on his affection for his slaves, writes: "I allow my slaves so to speak to make testaments and observe these as if they were legal," permitto servis quoque quasi testamenta facere eaque ut legitima custodio. ${ }^{147}$ Surely, Pliny is not speaking of quasi-testaments; he is not allowing his slaves to make a particular kind of testament; the quasi qualifies the whole phrase testamenta facere; he is allowing them, in a sense, to make wills. Even, however, if Pliny did here jokingly introduce a quasi-testament, it would have little bearing on the senatusconsult we are discussing. I am not denying that the formation of a term such as quasi-usufruct would have been possible. The classics just did not form it. There are more cases of a late quasi-something being read back into earlier layers in which all that is claimed is that a set of facts is treated as if it were that something. But I forbear from going on with this. 148

Beseler attributes remedio introducto to the compilers. ${ }^{149}$ I am reluctant to assent even to this modest excision, for three reasons. First, why ever should they have inserted the idea? Secondly, we shall find words to the same effect, per cautionem, "by means of a cautio," in Institutes 4.2 .4 going back to the Res Cottidianae. Thirdly, it will be remembered that Gaius follows Labeo in holding that furtum conceptum and furtum oblatum, theft taken hold of and theft inflicted, are not types of theft; they are called furta simply because they are actions made available in connection with this delict. The idea behind remedio introducto is much the same: this new institution is not usufruct; the senate calls it that because a remedy is provided-the cautio-connected with usufruct, indeed, typical of it, a remedy on the strength of which the case is looked on, dealt with, as if it were usufruct. That the term remedium is rare

\footnotetext{
145 E.g., Grosso, op. cit. supra note 128, Perozzl, op. cit. supra note 144, Albertario, Il possesso dell'usufrutto, dell'uso, della habitatatio, 2 STudr 328 (1941) (he is far too indiscriminate in his treatment of quasi).

146 Bonfante, Corso di Diritto Romano, Vol. 3, Diritto Reale 86 '(1933). It is presumably on the strength of his argument that the concept quasi-usufruct is accepted as classical in works like Jörs-KunKel-WEnger, Römisches Recht 146 (3rd ed., 1949), Kaser, 1 Das Römisghe Privatreght 380 (1955).

147 Pliny, Letters 8.16.1. For what this meant in actual fact see Biondi, Successione Testamentaria e Donazioni 84 (2nd ed., 1955). He does not deal with the problem here under notice. Translators mostly get the nuance wrong; e.g., Guillemin, 3 Puinz le Jeune, Letrres (Collection des Universités de France) 74 (2nd ed., 1959): d faire de quasi-testaments.

148 Quasi-delict, Stein has pointed out, appears first in BAsIlica 60.4.1: hosanei hamartema; see The Nature of quasi-delictal Obligations in Roman Law, 5 Revue INTERNATIONALE DES DROITS DE L'ANTIQUiTÉ, 3rd ser. (1958), p. 563.

149 Beseler, 2 BeIträge 121 (1911). For further intrusions alleged by him see supra, note 128 .
} 
in classical sources should not put us off. We have before us a semiphilosophical disquisition and, besides, remedium is the appropriate word. Actio, used in the explanation of furtum conceptum and oblatum, would have been far too narrow: the effectiveness of the new arrangement was ensured by taking over from usufruct-with adjustments-a special machinery, the main component of which was the cautio.

15. Justinian's Institutes on Usufruct Extended.-We come to Institutes 2.4.2, which Ferrini regards as descending from the Res Cottidianae. ${ }^{150}$ Usufruct, we learn, is possible over everything except perishable, consumable goods. "For these are susceptible of usufruct neither by natural nor by civil law reason." The same (the text goes on) applies to money. "However, for the sake of expediency, the senate decreed that also over those things a usufruct could be created, so, however, that the heir be given an adequate security." After some details as to machinery, the paragraph concludes: "hence the senate has not called into existence a usufruct over those things, for it could not do that, but by means of a cautio it has established a quasi-usufruct." 151

I suppose that, though gramatically the phrase "neither by natural nor by civil law reason" coordinates, puts on the same level, the two sources of law, what is meant is that, as perishables do not admit of usufruct by virtue of natural reason, neither will they admit of it in the strength of the civil law: the latter cannot go against the former. ${ }^{152}$ This is, of course, consistent with the principle enunciated in several passages from Gaius or dependent on him. Why, in the present case, there is mention of naturalis ratio I have just tried to explain in connection with Digest 7.5.2.1.153 In fact Institutes 2.4.2. makes it even clearer that it is a question of the sound order of things: the structure of usufruct, we are informed, is intrinsically averse to the inclusion of perishables.

The senate's awkwardly formulated regulation - awkward from the point of view of its commentators at least - was enacted utilitatis causa, "for the sake of expediency," that is to say, in order to assist urgent, decent needs and to prevent unfair results. This excuses some irregularity. Even so, the decree did not make the arrangement a usufruct, not even lege: the senate could not turn a nonusufruct into a usufruct. What it did was to introduce machinery from usufruct, a remedium in the language of Digest 7.5.2.1: "so, however, that the heir be given an adequate security," "by means of a

150 Frrarint, 2 Opere 361 [13 Bullettino 150f.].

151 Nam eae neque naturali ratione neque civili recipiunt usum fructum. . . Sed utilitatis causa senatus censuit posse etiam earum rerum usum fructum constitui, ut tamen . . heredi utiliter cavcatur. . . Ergo senatus non fecit quidem earum rerum usum fructum, nec enim poterat, sed per cautionom quasi usum fructum constituit.

152 Compare Drorst 3.5.38, Gaius III de verborum obligationibus.

153 VII ad edictum provinciale; supra, pp. $36 \mathrm{f}$. 
cautio." Just so, for the advocates of this line of argument, theft taken hold of and theft inflicted were species actionis furto cohaerentes rather than genera furtorum.

In one respect the author of the text goes considerably beyond Digest 7.5.2.1 where the arrangement "is considered as if a usufruct": in Institutes 2.4.2 the senate, by upholding it, "has established a quasi-usufruct." Read on its own, the clause quasi usum fructum constituit could mean "it has, so to speak, established a usufruct"; but after the preceding ergo non fecit usum fructum, "hence it has not called into existence a usufruct," this meaning is out of the question, and a translation like "it has established a quasi-usufruct" is unavoidable. Theophilus at any rate in his Greek paraphrase takes it this way: "By the device of the cautio the senate contrived an imitation of usufruct."154

A few more points in his paraphrase may be noted. He replaces the brief motivation in the Latin original "for the sake of expediency" by "since, then, it is said that there is no room for usufruct over those things." On the other hand, for the proviso "so, however, that the heir be given adequate security" he substitutes the short phrase "by a certain device"155: "a senatusconsult was enacted laying down that also over those things by a certain device a usufruct was to exist." In the course of explaining details, he stresses far more than the original the radical independence of the new case. The legatee receives ownership "contrary to the nature of usufruct, for usufruct is over another man's property; but as there exists no usufruct according to the laws over these things, fittingly the principles of usufruct are transgressed in their respect."156

If, as is most likely, the classics did not arrive at the concept of a quasiusufruct, Institutes 2.4.2 furnishes an argument for the postclassical origin of the Res Cottidianae. Segré, regarding the concept as postclassical, draws the inference that Institutes 2.4 .2 comes not, as Ferrini asserts, from the Res Cottidianae but from Digest 7.5.2.1. The inference is wrong. For one thing, as we have seen, Digest 7.5.2.1 does not contain the notion quasi-usufruct: this is only read back into it from Institutes 2.4.2. For another, the vocabulary is about as unlike as it could be - sed remedio introducto coepit quasi usus fructus haberi over against sed per cautionem usum fructum constituit - a

154 Dia tes methodou tes cautionos mimesin epenoesen usufructu. Ferrini, Institutionum etc., 126, completely disregards the mention of methodos, "device," "stratagem," as he also removes the nuance of purposeful planning or scheming from the verb epinoeo. He translates: per cautionem vero quasi usumfructum introduxit.

155 Dia methodou tinos. Ferrini's quadam ratione, op. cit. supra, n. 49, is not pregnant enough.

156 Very similar to Levy, quoted supra note 137. Para ten physin tou usufructu, ho gar usufructos kata allotrias despoteias estin; all epeide ou synesteke epi touton kata nomous ho usufructos, eikotos kai hoi kanones epi auton parabainontai tou usufructu. 
fact Segré notices but is unable to account for. The point is that, in his day, the possibility of the Res Cottidianae being postclassical did not yet occur, hence, he was practically driven to his mistaken conclusion.

We might, indeed, consider the possibility that Justinian altered the text of the Res Cottidianae in the points here of relevance. A possibility, to be sure, but an exceedingly remote one. Or again, it might even be argued that quasi-usufruct was invented by Gaius between his commentary on the provincial edict and his (genuine) Res Cottidianae. I am not the Jew Apella.

16. Paul and Ulpian on Usufruct Extended. - In both the provinces of theft and usufruct, Labeo's doctrine prevailed: the law cannot turn facts which do not constitute such and such an offense or transaction into that offense or transaction, it cannot add a "legal" class to the "natural" one. Gaius, Gellius, Justinian, Theophilus - they all follow this doctrine. For usufruct, Paul and, perhaps, Ulpian may be included in the list of witnesses.

Usufruct was lost by nonuse, for one year in the case of movables, for two years in that of land. (Justinian extended these times.) But this mode of extinction did not apply to quasi-usufruct ${ }^{157}$ - obviously, it would have made no sense, the quasi-usufructuary becoming owner of the objects, the wine, oil, money. Paul puts the matter thus: "Also if a usufruct over money is bequeathed it does not end by nonuse for a year, because it is not usufruct and the ownership of the money is with the usufructuary, not with the heir."158 The particle quoque connects up with the preceding remark to the effect that, in contradistinction to usufruct (ordinary usufruct) already in existence, the action by which you may claim to have it created is not lost by nonuse. This leads on to quasi-usufruct not lost by nonuse. "It is not usufruct," Paul declares: this is in accordance with what we found in Gaius. Like Theophilus, Paul names the usufructuary's ownership of the objects as the fundamental deviation; for Theophilus, we have seen, quasi-usufruct is "contrary to the nature of usufruct, for usufruct is over another man's property."

In the course of discussing the oath which, given certain conditions, settles a right, Ulpian observes: "But if he swears that he has, or that there is owing to him, a usufruct over things over which because of consumption a usufruct cannot be created, I opine that the effectiveness of the oath should be

167 Institutes 2.4.2, Fragmenta Vaticana 46, to be discussed presently, Diogst 7.5.9, Paul $I$ ad Neratium, 7.5.10 pr. [equals-7.9.7.1], Ulpian $L X X I X$ ad edictum. In fact, nearly all modes of extinction of usufruct proper were inapplicable.

158 Fragmenta Vaticana 46, Paul I Manualium: Pecuniae quoque usus fructus legatus per annum non utendo non perit, quia nec usus fructus est et pecuniae dominium fructuarii, non heredis, est. The words non perit are supplied by HuschKe IURISPRUdentiae ANTEIUSTINIANAE QUAE SUPERSUNT 691 (3rd ed., 1874), and certainly give the right sense. I do not see some of the difficulties Grosso, op. cit. supra note 128, at $264 \mathrm{ff}$., has with the text. 
accepted and therefore I believe that even then he should be considered to have correctly sworn and he can on the strength of the oath claim the usufruct on offering the security." 159

To begin by taking the text as it stands, the question is whether to recognize an oath in which a quasi-usufruct is described as a usufruct. The very question implies a firm insistence on the view that it is not usufruct, be it natura or be it lege. The decision, it is true, prefers a sane and fair result to rigorous logic and, with some hesitation (arbitror, puto, "I opine," "I believe") the oath is upheld.

Beseler reconstructs the decision as follows: "I opine that the oath has no effect."160 If he is right, Ulpian carried the exclusion of quasi-usufruct from usufruct to extremes - perhaps not impossible where it is a question of interpretation of an oath.

I agree with Beseler that the text is doctored, ${ }^{161}$ but I should seck to restore it along different lines. The clue seems to me to lie in the switch from the first person in the first half of the paragraph, not here quoted, item si iuravero, "if I swear," to the third person in the second half, the half we are concerned with, sed si iuraverit, "but if he swears." Beseler puts it right by inserting quis into the latter case, sed si quis iuraverit, "but if somebody swears." This, I think, is too simple. I think that, in the original Ulpian, between the first half and the second there was a discussion which the compilers found inconvenient and dropped. The first half deals with extinction of usufruct proper. The bit dropped may have continued this theme. And even the second half, here under notice, may originally have had to do with it, pointing out - as does Fragmenta Vaticana 46 - differences in the case of quasi-usufruct.

If so, there is no knowing the exact question Ulpian had in mind; but it was most probably not the description of a quasi-usufruct as a usufruct. ${ }^{162}$ That this is the problem now would be the doing of the compilers.

17. Gaius on Adoptive Relations and Ulpian on Conventional Infamy; an Excursus on In-laws. - An argument from silence is apt to be precarious.

169 Drosst 12.2.11.2, Ulpian $X X I I$ ad edictum: Sed si rerum in quibus usus fructus propter abusum constitui non potest iuraverit usum fructum se habere vel sibi deberi, effectum iurisiurandi sequendum arbitror ideoque tunc quoque videri eum recte iurasse puto et ex eo iureiurando posse petere usum fructum cautione oblata. See Grosso, op. cit. supra note 128 , at $266 \mathrm{ff}$., with whose results I am not in full agreement; my principal argument is not much affected.

$160 \mathrm{Et}$ (atque) ideo, et (atque) idcirco, ideoque, idcircoque, Beseler, 45 ZeItschript DRR SAviony-Stiftuno (1925) (Roman section) 462: nullum esse effectum iurisiurandi arbitror.

161 That propter abusum is not classical was noted above, p. 35. Beseler cuts it out. It may, however, be an abbreviation of something like quia usu consumuntur, "because they are consumed by use."

162 Compare, infra, pp. 45f., for Ulpian's attitude to a comparable problem from "infamy." 
Still, from our sources it does look as if the Roman jurists had embarked on an ex professo inquiry into an extension of a category only in connection with these two cases: the manifest theft if an object is found by ceremonious search "with loincloth and platter," and the usufruct over perishables. It is only here, it appears, that they set forth, gave explicit shape to, their theories the category lege on the one hand, the explanation by means of "as if" or quasi on the other. Why should that be so? There would have been many other opportunities, the whole, vast field of interpretation, for example. The very term "manifest theft," as Gaius himself points out, ${ }^{162 a}$ was far from unambiguous, construed in a narrow sense by some jurists (the thief must be caught in the act, on the spot), less rigorously by others (he must be caught before having carried the object to safety).

The answer is that, in these two cases, there was legislation - known legislation - declaring a set of facts to be what prima facie it was not: "it shall be manifest theft," "it is a good usufruct." These provisions had to be made sense of and thus, in a time greatly interested in definition and classification, the discussion of principle was sparked off. In the course of it, or rather in the course of discussing "with loincloth and platter," three other cases were drawn in: theft as such, adultery, and homicide. Theft as such, because of the long-standing allied problem which had cropped up in endeavors to work out various types of theft, with theft taken hold of and theft inflicted becoming increasingly difficult to fit in; and adultery and homicide, because as to both there was also extending legislation - though these extensions were more carefully worded, with the aid of pro, quasi, ut.

Needless to say, if the ex professo ventilation of the problem is confined to a very few contexts, adumbrations and echoes abound throughout the system. Above I quoted Institutes 3.1 .11 on adoption, ${ }^{163}$ and it is instructive to pay attention to the way adoptive relationships are described there and elsewhere. A few sketchy remarks must here suffice. In his Institutes Gaius, who rejects manifest theft lege and usufruct lege, freely speaks of "adoptive son" or "adoptive father," filius or pater adoptivus. ${ }^{164}$ (The use of liberi in this area is not determined by absolutely the same factors since, though the word mostly signifies "children," its wider, basic meaning "free persons" and then "free subjects of a paterfamilias" is not without some influence.) Sometimes he represents them as occupying "the place of" natural relations, ${ }^{165}$

\footnotetext{
16i2a Galus 3.184. Mr. Colin Turpin, of Clare College, Cambridge, has kindly drawn my attention to this remarkable fact. Cf. supra, note 140, and infra, note $186 \mathrm{a}$.

163 See supra, pp. $10 \mathrm{ff}$.

164 Galus 1.137 a, $2.136,137,147,3.40,41,46,49,83,84$.

165 Garus 1.59, eamque mihi per adoptionem filiae loco esse coeperit, "a woman who through adoption begins to be in the position of a daughter to me," 2.136, adoptivi filii naturalium loco sunt, "adoptive sons are in the place of natural ones."
} 
which chimes with his thesis in regard to extensions in other fields. But he is far from consistent, as when he says: "If a woman through adoption begins to be a sister to me."166 In Institutes 3.1.11, from the Res Cottidianae, the thesis seems to be carried to greater lengths: adoptive children have "the mere legal title of son or daughter," ius nomenque. The late classic Modestinus in his Regulae is not unsubtle, considering that in this kind of work a terse statement is called for: "Not only nature but also adoptions make sons of families." $167 \mathrm{He}$ says not that adoptions make sons but that they make "sons of families." The latter is a more technical notion, more directly referring to the quality of the persons concerned as subjects of the heads of families. Whether adopted sons merely acquire the place of natural sons or become sons lege he does not decide.

Of adrogatio, the adoption of one paterfamilias by another, we know the formula designed for it by Q. Mucius Scaevola around 100 B.C. The popular assembly was asked: "Do you wish and ordain that Lucius Valerius be a son to Lucius Titius by law and statute just as if he were born of that father and his wife, and that to Titius be power of life and death over Valerius as is to a father over a son?"'168 The archaic formula is not yet dominated by a definite, consciously held theory. Mucius's academic grandson Servius ${ }^{169}$ would find here ammunition for his category lege - the person arrogated is iure legeque filius - but equally the "as if" school might derive comfort from "just as if he were born," tam siet quam si esset. I suppose that in both adoption in the narrow sense and arrogation, at all stages, the way the new relationship was thought of would depend a little on whether, in any given case, attention focused on the power-subjection aspect, the filiusfamilias as comparable to the paterfamilias's ordinary property, or whether it focused on the more elementary characteristics of fatherhood, sonship, brotherhood, sisterhood and so on. In the former case, the difference between a true and an adoptive relation would be less conspicuous than in the latter; which means

106 Galus 1.61: si qua per adoptionem soror mihi esse coeperit.

167 Draest 1.7.1 pr., II regularum; filiosfamilias non solum natura, verum et adoptiones faciunt. Monro, 1 The Droest of Jusminian 31 (1904), under the influence of passages with "in place of," translates: "The position of filiusfamilias is acquired not only by nature but by adoption."

168 Gellius 5.19.9: Velitis iubeatis uti L. Valerius L. Titio tam iure legeque filius siet quam si ex eo patre matreque familias eius natus esset, utique ei vitae necisque in eum potestas siet uti patri endo filio est. A MS. of the thirteenth century reads "become son" and "to Titius become power," fiet instead of siet; see Aulus Gellius, Noctium Atricarum LIBRI XX, book 1, 321 (ed. by Hertz, 1883). In the script of the period, $f$ and $s$ were very close. Nevertheless it is probable that the copyist did find siet a difficult thought: at this moment the sonship is not yet created. But siet is, of course, correct. The falling together of assertion and creation of a right is known, for instance, from mancipation; and at any rate, siet, occurring as it does in a question to the assembly, may well look forward to a legislative esto.

169 Mucius taught Aquilius Gallus and Lucilius Balbus, who in turn taught Servius. 
that the concept "father, son, brother, sister lege or iure" would present itself more readily in the former, that "in the place of a father, son, brother, sister" in the latter.

To give one more example from a remoter branch of the law. "Infamy" was not uncommonly incurred by a man who could hardly be considered a scoundrel; for instance, by a tutor whose negligence - negligence, not fraud - was found to have caused his ward some loss. The praetorian edict attached the same disabilities to condemnation in actio tutelae as to condemnation, say, in an action on the ground of theft and only slightly fewer than to condemnation in a capital trial; and in the lex Julia municipalis the three cases attract the same disabilities. ${ }^{170}$ Ulpian comments: "Some kinds of opprobrium are dishonorable by nature, some by the civil law and so to speak by the usage of the State; for example theft or adultery is dishonorable by nature, whereas to be condemned in the actio tutelae, that is not an opprobrium by nature but by the usage of the State. For that which can befall even a worthy man is not an opprobrium by nature." 171

A jurist opposed to manifest theft lege or usufruct lege ought perhaps not to have recognized the dishonorable or opprobrium more civitatis; the logical view would have been that condemnation because of negligence is treated as if it fell under those attributes. Apart from the fact, however, that the jurists were not always logical, I argued above, in discussing quasi-usufruct, that we do not really know where Ulpian stood in that controversy. 17.2 To judge by the present fragment, he did not in fact follow the main trend. But to attain anything approaching certainty, a much more thorough investigation would be needed.

The fragment comes from Ulpian's chapter on iniuriae, attacks on the person, and Lenel seems to think that it was concerned to explain precisely what aspersions constituted actionable slander: you would be liable if you spoke of a man as found guilty of theft or adultery, dishonorable by nature, but not if you spoke of him as found guilty in an actio tutelae, an opprobrium only by usage of the State. ${ }^{173}$ This is a perfectly possible context, but I incline to assume a different one. Ulpian may well have been exercised by the fact which has very understandably exercised modern authorities such

\footnotetext{
170 Greenidge, Infamia 121ff. (1894); Mommsen, Römisches Strafrecht 805f., 993f. (1899); Watson, Some Cases of Distortion by the Past in Classical Roman Law, 31 Tijdschript Voor Rechtsoeschiedeis 76ff. (1963).

171 Diosst 50.16.42, LVII ad edictum: Probra quaedam natura turpia sunt, quaedam civiliter et quasi more civitatis, ut puta furtum, adulterium natura turpe est, enimvero tutelae damnari hoc non natura probrum est sed more civitatis. Nec enim natura probrum est quod potest etiam in hominem idoneum incidere.

172 See supre, p. 42.

173 Palingenesia, vol. 2, 777, Edictum, 397, adducing Diasst 47.10.15.13, from the same book by Ulpian.
} 
as Mommsen and Watson ${ }^{174}$ - that condemnation in the actio iniuriarum involved infamy though, in many cases, this would appear quite unjustifiable. It was this criticism he answered by the distinction between "natural" disgrace and "conventional" disgrace, and the actio tutelae came in as a further illustration: here, too, to understand the law one had to resort to this distinction.

Beseler considered Lenel's suggestion implausible and labelled the fragment as spurious. ${ }^{175}$ Why it should be necessary to deny Ulpian's authorship if the context suggested by Lenel does not convince I fail to see. I am conjecturing a different context; yet Lenel may be right, or neither of us no reason here for condemning the fragment. Kaser tries to reinforce Beseler's excision by the strangest argument. 176 It contains the following steps. (1) Mos civitatis "can here signify only the feelings, views, judgment of the Roman people," kann hier nur die römische Volksanschauung bedeuten. (2) The main distinction in the field of infamy, however, is between cases where infamy results automatically from certain conduct (from working as a gladiator, for example - so-called "immediate" infamy) and cases where it results only from judicial conviction (the three cases in the present text all fall under this "mediate" infamy, you become infamous not when you steal, commit adultery, or are remiss in your job as tutor, but only by being convicted of theft, of adultery, or in an actio tutelae); and with this main distinction the one made in the present text between "natural" infamy and infamy in accordance with the römische Volksanschauung has no detectable connection. (3) The connection is not rendered any clearer by the final clause, nec enim, etc., "for that which can befall," etc., which is in any case naive. To these arguments one may reply: (1) There is nothing to justify the interpretation of mos civitatis as die römische Volksanschauung. It has its usual sense, "usage, established tradition, custom, of the State." This is contrasted with natura just as lex is in the discussion of "loincloth and platter." (2) Ulpian is plainly not concerned with the distinction between "immediate" and "mediate" infamy (a distinction which, though most useful, was worked out by Savigny). ${ }^{\mathbf{1 7 7}}$ All his three illustrations are cases of "mediate" infamy; there is no vestige of another. So no objection can be based on the fact that a connection with that distinction is not detectable. (3) Nor can we expect the final clause to elucidate this connection, which

174 See supra note 170.

173 Beseler, 5 BeIträge 75. The words civiliter et quasi, already questioned by Albertario, are probably an intrusion.

176 Kaser, Mores maiorum und Gewohnheitsrecht, 59 ZEITschrift der SAvignyStiftung (1939) (Rom. Abt.), 93.

177 Greenidge, op. cit. supra note 170 , at $38 \mathrm{f}$. 
is not there. As for the naivete of this clause, that criticism has some weight so long as we translate idoneus by "suitable," "fit for the job." Then it would indeed be a little naive to say that what can befall a man suitable for the office of tutor cannot be disgraceful by nature. But idoneus shades off into "worthy," "honest,"178 and though in the legal sources this nuance is rare, a discussion of infamy is the place for it.

May I be permitted an excursus on father-in-law, brother-in-law and so on? At first sight we seem to have before us a father lege or iure, a brother lege or iure, that is to say, a father or brother the law has added to the genuine one. The New English Dictionary does take this line. It explains that "in-law" means "in canon law." The contrast is with father or brother in blood, by nature. The terms with "in-law" imply that, as regards intermarriage, these persons fall under the same prohibitions as a true father, brother, and so on; they are, for this purpose, a father, brother, and so on created by the law. ${ }^{179}$

I am highly skeptical about what would be an amazingly early - tnirteenth century - appearance in common English parlance of so sophisticated a concept. What increases my doubts is the idea that these relations should have received their designations from the forbidden degrees - especially as in some important cases a designation so based would make nonsense. My wife's brother is my brother-in-law: ${ }^{180}$ because he is forbidden to me like my true brother? Again, stepfather and stepmother, who would best suit the category of a father and mother created by law, are not called fatherin-law or mother-in-law before the sixieenth century, and the designation never quite stuck to them. ${ }^{181}$ Last but n'st least, the earliest instance - about 1250 - of the use of "in-law" is wife-in-law, signifying a lawfully married woman. It antedates the other uses by at least half a century. It might perhaps be argued that this is an accident of transmission. The fact remains that wife-in-law is very ancient, and that the explanation of the New English Dictionary does not fit at all. A wife-in-law, a lawfully married woman, is not a wife added by the law to a wife in blood or by nature. She is the one wife. ${ }^{182}$

178 E.g., Cigero, De Officcirs 2.62; Quintilian, 2.15.31, Deglarationes 376 at the beginning.

179 This account is given under "brother-in-law" (first in alphabetical order), New Enolis H Dictionary vol. 1, p. 1133 (ed. by Murray 1888). For the remaining in-laws, and also under the heading of "in-law," vol. 5, p. 306 (ed. by Murray 1901), we are referred back to this basic entry.

180 Brother-in-law is among the early in-laws: A.D. 1300. See New English Dictionary at "brother-in-law."

181 New Enolish Dictionary vol. 4, p. 99 (ed. by Bradley, 1901) ; vol. 6, pt. 2, p. 694 (ed. by Bradley, 1908).

182 Actually, we might see indirect attestation of wife-in-law as early as about 1230, in Hall Meidenhad, 18 Early Enclish Text Society 21 (Cockayne ed., 1866). Women weak enough to marry are here called such as "are in the law of wedlock." At 
The correct solution seems to be this. The term wife-in-law does in fact stand at the beginning. The noun wife at that time might denote any woman married or unmarried - as Weib still does in German. Therefore, where her status as legitimate spouse was to be stressed, she was described as wifein-law, i.e., wife (woman) taken in the law of wedlock. Father-in-law, brother-in-law, and so on were formed by way of extension, the attribute "in-law" referring to the area of wedlock: father-in-law, brother-in-law meant father, brother, in the area of wedlock, father, brother, of the woman who is my lawful spouse - not father, brother, added by the law to father, brother, by nature. Gradually the noun wife became narrowed down to married woman, and wife-in-law dropped out. It was from then onwards that fatherin-law and so on could be and sometimes were in joke or earnest represented as father by virtue of law as opposed to the natural.

In Monstrelet's Chronicles, written in the fifteenth century, there occurs the expression père en la loi de marriage: Jean Petit in his defense of John the Fearless in 1408 mentions that the latter was made the Dauphin's father in the law of marriage. ${ }^{183}$ This fully chimes with my view that father-in law originally means not a father lege or iure but a father in the area of wedlock, the lawfully wedded spouse's father. In the recently published Oxford Dictionary of English Etymology 184 the English "in-law" is said to be coined "after AN. [Anglo-Norman] en ley, OF. [Old French] en loi (de mariage)." I have not been able to trace any evidence for en ley, and the only evidence for en loi known to me is the passage from Monstrelet just adverted to. ${ }^{185}$ Admittedly, even should there be in fact no further evidence, the possibility of a Norman-French provenance of "in-law" cannot be ruled out; it makes no difference to my main point. But it could also be that it is the English, well attested from the thirteenth century, which comes first and is responsible for the French. Jean Petit, incidentally, was a native of Normandy. Let me add that, if my explanation is correct, the English (or Norman-French) development is basically much closer to the German than has so far been assumed: Schwiegervater, Schwiegersohn mean father, son in the area of Schwägerschaft, of affinity through wedlock.

18. Extension by Interpreters and Moralists; the Praetor. - It would be

least this passage provides additional justification for questioning the derivation of "in-law" from the forbidden degrees.

183 Book 1, ch. 39 towards the beginning.

184 Ed. by Onions with the assistance of Friedrichsen and Burchfield (1966) 476.

185 It is cited by Goderroy, Dictionnatre De L'ANGienne langue prancaise vol. 5 (1888), 17, and, from there, by the New ENGLish Dictionary vol. 6, 1.c. In the latter entry, the phrase is attributed to the sixteenth century, presumably because Godefroy refers to a 1516 edition of Monstrelet. But it is already in the fifteenth-century copies and may actually go back to Jean Petit's address. 
interesting to see whether, and how far, the Roman jurists deemed their reflections on statutory extension of a category applicable to extension of a category by way of interpretation. Interpretation can at times assume a near-legislative stance - Wer ein Arier ist, bestimme ich, said Göring ${ }^{186}$ - in which event the problem might become quite similar. However, this is too big a field for this discussion. ${ }^{186 a}$

A fortiori the field of morality, though inviting comparison, is too big. In general, in the sphere of morality, with no trial in prospect, considerable freedom is taken with the wrongs known to the law: they are apt to be more expansively conceived. La propriété, c'est le vol, says Proudhon, "property is theft," Eigentum ist Raub. It is noteworthy, however, that in the moral writings of the Romans, there is relatively little of this. Probably the most familiar ancient illustrations are from Rabbinic and New Testament literature. Here, the moralist will frequently oppose his wider notion to the lawyer's narrower one. Take these extensions of adultery and murder: "Thou shalt not commit adultery (Exodus 20.14, Deuteronomy 5.17) - not even with the eye, not even in the heart"; 187 "The eye of the adulterer waiteth for the twilight (Job 24.15) -lest you should think that only he who commits adultery with his body is called an adulterer by Scripture: he also who commits adultery with his eye is called an adulterer by Scripture";188 "Whoever looks at (or, thinks about) a woman with desire is as if he had cohabited with her"; 189 "Ye have heard thou shalt not commit adultery, but I say unto you that whosoever looketh on a woman to lust after her hath committed adultery with her already in his heart"; 190 "He who puts his fellow to shame in public is like a shedder of blood"; 191 "He who hates his fellow belongs to the shedders of blood"; 192 "Ye have heard thou shalt not kill and whosoever shall kill shall be in danger of the judgment, but I say unto you that whosoever is angry with his brother without cause shall be in danger of the judgment."193 Anyone guilty of the essential, wicked element of the crime is included. It may well be significant, however, that in none of these quotations do we meet a simple pronouncement "He who desires another man's wife is an adulterer," "He who hates his fellow is a murderer." There are little reservations: "is

${ }^{186}$ Following in the footsteps of Karl Lueger; see Keller, The City Behind the Charm (book review), Sunday Times of June 12, 1966, p. 28.

$186 \mathrm{~s}$ See supra, p. 43 , for a reference to the various interpretations of "manifest theft."

187 Mekhilta de-Rabbi Shimeon 111.

188 Leviticus Rabba 23, Resh Laqish.

189 Kalla 1.

190 Matthew 5.27f. On the half-interpretative, half-autonomous form of this saying, as well as 5.21f. to be quoted presently, see Daube, The New Testament and Rabbinic Judarsm 55ff. (1956).

191 Babylonian Baba Metsia 58b.

192 Derekh Erets 10, R. Eliezer ben Hyrcanus.

193 Matthew 5.21f. 
called such and such," "is as if," "has done so and so in his heart," "is like," "belongs to those who." Enough - I just wanted to remind readers of this province.

Yet another inquiry I skip. I might at this juncture compare the praetor's inability (in classical law) to change the civil law directly: "the praetor cannot make heirs," says Gaius, "though when he gives persons passession of the estate, they are established in the position of heirs."194 But let me pass on to a very different theme.

\section{INTERference WTTh the Past}

19. Nineteen-eighty-four. - The desire to reshape the past occurs in all spheres of life; I mean actually to reshape it — not merely to feign it different or to set it to rights now and for the future, but to interfere with yesterday, to make things that did not happen to have happened and vice versa. Rationally we know that what is done cannot be undone, ${ }^{195}$ quod factum est infectum fieri non potest, ce qui est fait ne peut être défait, man kann das Geschehene nicht ungeschehen machen. But the very existence of this proverb in many languages testifies to the strength and ubiquity of the impossible hope: Lady Macbeth desperately wished it were otherwise. ${ }^{196}$

The Rabbis discourage a prayer such as that a sound of lamentation you hear from afar may not be over one dear to you, or that the child your wife is expecting may be male. The prayer is "vain": the victim over whom they lament is already in being, as is the sex of the child conceived, and even God cannot or will not undo or remake the past. ${ }^{197}$ This (apparent) restriction on God is an old theological conundrum. ${ }^{198}$ Yet people do pray in this way, "Let it not have happened," "Let me be the prize-winner" (on going up to the notice board). It is precisely in the religious world that time is often felt to be conquerable. Renewal of the pristine creation, rebirth in conversion, are examples. "Behold, I create new heavens and a new earth, and the

194 Garus 3.32.

195 But see Davy, Time May Go Back in Faustian Universe (reporting an article by Stannard in NATURE), Observer of August 14, 1966, p. 1.

196 William Shakespeare, Macbeth, Act V, scene 1, line 75.

197 Mishnah Berakoth 9.3; the Hebrew for "vain" is shav'. Opinions diverging in varying degrees are recorded in Palestinian Berakoth 14a, Genesis Rabba 72 on Genesis 30.21 ; none of them, however, reckons with a retroactive intervention on the part of God. This is not the place to raise the question whether, on a rigorously mechanistic-causal view of nature, one could ever pray for anything but a miracle.

198 E.g., Abraham Tucker (Edward Search), Light of Nature vol. 2 (1768), pt. 1, 196f., in a chapter on Omnipotence discusses "absolute impossibilities which appear such even to Omnipotence itself, such as . . . annihilating time and space, undoing past events or producing contrary ones." His explanation is that "those things imply contradictions, and contradictions are generally held to be no objects of power as their possibility would infer a defect rather than an enlargement of power." 
former shall not be remembered," says the prophet.199 "Though your sins be as scarlet, they shall be white as snow"200 — the promise here is of more than a writing off, they will never have been; "I will allure her into the wilderness and she shall sing there as in the days of her youth"201 — this means a new beginning, with all that ever clouded the marriage annihilated; and the prayer "renew our days as of old"202 longs for.. just this miracle. (Our "to wipe the slate clean" tends in the same direction.) A convert to Judaism becomes a newborn child in so real a sense that his previous bloodrelations are no longer related to him: this affects the law of inheritance and he may also, for instance, enter into what would otherwise be an incestuous marriage. 203 The Greeks made a person returning from abroad after being reputed dead undergo a rebirth, a custom modern treatises on Greek law assign to the section about fictions. ${ }^{204}$ Plutarch, who mentions the rite, would presumably have agreed, ${ }^{205}$ but one may wonder whether it was not once looked on as, let us say, three-quarters real.

In history, we call an aetiological myth one that is invented ex post facto in explanation and, frequently, in support of an existing situation. To some extent the story of Jacob's struggle with the angel is of this type - explaining why the Israelites abstain from certain portions of an animal. 206 Often such myths support a right. We may think of the various biblical tales showing why, though of the twins Esau and Jacob the former was the firstborn, the latter's descendants must be superior to his: an oracle before they were born, an extraordinary occurrence at birth, Esau's sale of his birthright, Jacob's success in obtaining their father's blessing. ${ }^{207}$ Genealogies furnish prominent instances of aetiology. "To return to our wethers," says Rabelais, "I say, that by the sovereign gift of heaven, the antiquity and genealogy of Gargantua hath been reserved for our use more full and perfect than any other except that of the Messias, whereof I mean not to speak; for it belongs not to my purpose, and the devils, that is to say, the false accusers and dissembled gospellers, will therein oppose me."20s

199 Isaiah 65.17, taken up in Revelation 21.1.

200 Isaiah 1.18.

201 Hosea 2.14f.

202 Lamentations 5.21.

203 E.g., Babylonian Yebamoth 22a, 97b f., Palestinian Yebamoth 12a. For certain modifications laid down in order that he should not think Judaism was lax in questions of incest, see Dauge, The New Testament and Rabbinic Judaism 113. From the middle of the third century the principle began to be undermined: this is behind the view $R$. Johanan opposes to that of Resh Laqish, Babylonian Yebamoth 62a.

204 J. Walter Jones, Law and Legal Theory op The Greeks 306 (1956):

205 Plutarch, Roman Questions 5, 264E ff.; compare Lucullus 18.1.

208 Genesis 32.32.

207 Genesis 25.23, 25.26, 25.33, 27.1ff.

208 Rabelais, Gargantua, Book 1 , ch. 1, in Urquhart's translation. 
Exactly what was the attitude - or better, were the attitudes, or still better, were and are the attitudes - of aetiologists to the past? It would be naive to think that the phenomenon is confined to antiquity. And what the Ministry of Truth will do in 1984, we know: "Who controls the past, controls the future, who controls the present, controls the past. Oceania was at war with Eurasia, therefore Oceania had always been at war with Eurasia. As short a time ago as February, the Ministry of Plenty had issued a promise that there would be no reduction of the chocolate ration during 1984; the chocolate ration was to be reduced; all that was needed was to substitute for the original promise a warning that it would probably be necessary to reduce the ration at some time in April." This will be "reality-control," when previous descriptions and predictions will not be "altered" but "rectified."209

Insofar as interpretation or reinterpretation of laws purports to conform to their true meaning, the problem is closely related. As early as under the legis actio, the Roman experts were prepared to let a man whose vines, vites, had been cut down cash in a fine the XII Tables imposed on the cutting down of trees, arbores. ${ }^{210}$ There is no study on interpretation that does not revel in the presentation of judgments attributing incredible meanings to the authoritative text. The Talmud has a scene where Moses visits R. Aqiba's academy (he died under Hadrian) and cannot follow the discussion; he is satisfied, however, when assured that their decisions do go back to his revelation at Sinai. ${ }^{211}$ Irrebuttable evidence, irreversible judgments - in particular, annulments of acts gone through or ratifications of collusive litigation - may all produce remodellings of the heretofore; as when Catherine of Aragon "was divorced and the late marriage made of none effect." 212

In the commoner legal disputes, the urge to intervene in the past normally aims at a negative - to undo what did happen rather than to put up what did not: people quarrel or go to law when they are dissatisfied with the course things have taken. (I am not pronouncing on how far the distinction is one of substance and not merely of aspect.) An expression like restitutio in integrum, "restoration to the untouched position," is significant: the praetor might grant it where a person's rights had been adversely affected by some event. ${ }^{213}$ Similarly, if a Roman returned from captivity, he recovered pristina iura, "his pristine rights."214 A man suspected of trying to get out of a

209 Grorge Orwell, Nineteen-eighty-four 37ff. (1949).

210 Garus 4.11 . In the case recorded by Gaius plaintiff lost because he rested his claim on a statute speaking of vites - there was no such statute.

.11 Babylonian Menahoth 29b. On some aspects of the question, see my Texts and Interpretation in Roman and Jewish Law, 3 Jewish Journal of Sociology 3ff. (1961).

212 Shakespeare, Henry VIII, Act 4, Scene 1.

213 See Buckrand, op. cit. supra note 135, at 719.

214 By the special regulation of postliminium: Galus 1.129 . 
bargain by denying it is rebuked: "You hope to be able by dissimulation. to render this unmade," speras potesse dissimulando infectum hoc reddere. 215 The parties to a sale might from the start agree that if the price is not paid by a certain date, the object should be inempta, "unbought."216 From the international field, there is the peace treaty concluded in 321 B.C. by the generals of the Roman army with the Samnites who held them blocked in the narrow Caudine pass. When the army was safely back at Rome, the senate repudiated the treaty as unauthorized. The Samnites pleaded that such repudiation was fair only if Rome "restored those legions into the defile where they were surrounded": "let everything be as if it had not happened" - restituat legiones, omnia pro infecto sint. ${ }^{217}$ There were indeed some Romans who took this view: the treaty could not be shaken off "unless all was restored to the Samnites just as it had been at Caudium," nisi omnia Samnitis qualia apud Caudium fuissent restituerentur. ${ }^{218}$ Naturally, expediency prevailed over scruples.

In none of these cases, however, does the law step outside the boundaries of the rational. Though the desire may be for direct alteration of the past, fulfilment is a different matter. The limitations of the latter are clearly realized. One method by which effect was given to a restitutio in integrum was an actio rescissoria, advising the judge to deliver his verdict as if the damaging event had not occurred - an open admission of it. ${ }^{219}$ A returned prisoner did not, for example, automatically recover possession and marriage, at least not in classical law, when these were regarded as primarily factual relations; Justinian, to whom marriage meant more, introduced some reforms. 220 An object which had become "unbought" might still have to be retransferred into the vendor's ownership. ${ }^{221}$

20. "And His Place Shall Know Him no More."-Especially in the political domain, the irrational may triumph. Let us look at what we might call abolitio memoriae, "abolition of a person's memory." (The ancient sources contain only the verbal form abolere memoriam, "to abolish a memory"; the

215 Plautus, Mostellaria 1017.

216 Lex commissoria, Digest 18.3.

217 Livy 9.11.3f.

218 Livy 9.8.14.

219 Buckland, op. cit. supra note 135 , at 723 .

220 Id. at 67.

221 Id. at 497 . Where the contract fell to the ground under a lex commissoria, the Sabinians gave actio empti or venditi to settle matters, the Proculians only an actio in factum. This controversy, however, does not represent a rational attitude to the past on the part of the Sabinians versus an irrational one on that of the Proculians. The latter simply argue that according to the agreed, retroactive, resolutive condition no sale has come about, whereas the former give contractual actions as soon as the orbit of sale is entered. See my essay on Certainty of Price, in Studies in the Roman Law of Sale 32f. (ed. by Daube, 1959). 
step to the category "abolition of a memory" is not yet taken. ${ }^{222}$ ) We may begin with a modern episode. In 1933, the Oxford Union passed a resolution "in no circumstances to fight for King and country." Randolph Churchill, disgusted, moved, not another resolution to revoke this one, but a private business measure - to expunge the offending resolution from the records. Evidently, he tried to cause it not to have happened. Before his proposal could be debated (when it finally was, it was defeated), wilder men sharing his feelings tore the page from the minute-book and burnt it at the Martyrs' Memorial. ${ }^{223}$

At Rome, the elimination of a ruler might be followed by a rescission of his decrees and the overthrow of his statutes. (There is ample discussion in modern literature of rescissio actorum, ${ }^{224}$ but, again, the sources contain only the verbal rescindere acta.) So far so good: these are actions to reject and improve upon the past, not to influence it directly. The cutting out of the hated man's name from inscriptions goes further; and in some cases he was removed even from the fasti, the official calendar showing, for example, the years when he had occupied the consulate. He had never been, or at least never been in those positions of honor. The first case for which this extreme measure is evidenced is that of Marc Antony in 30 B.C. It is interesting that Hirschfeld, writing in the second half of the nineteenth century, found it diffcult to accept that a sober chronological State register could be treated thus, getting a hole torn into it. ${ }^{225}$

Already Cicero in 56 B.C., in his speech Pro Sestio, said of the consuls of two years before: "those consuls, if they are to be called consuls who there is nobody but thinks should be torn out not only from human memory but also from the fasti."226 Translators are apt to tone it down, rendering, for example, "whose names" instead of "who" ought to be torn

222 It is curious that Vittinghoff, while aware that damnatio memoriae is modern - the sources speaking only of damnare memoriam - does not seem to notice that the same is true of abolitio memoriae. There is much to be said, however, for his contention that damnare memoriam refers not to the condemnation, abolition, of a person's memory but to the posthumous sentencing of a person guilty of perduellio: DẹR STAATsfeIND IN DER Römischen KaISERzeit 12f., 47, 64ff. (1936).

223 Hollis, The Oxford Union 187 (1965). I asked some experts in Union affairs what would have happened if the page had not been illegally torn out and Churchill's proposal had been approved. They think that probably the page would have been not torn out, but crossed out with two huge strokes, though a tearing out would not be inconceivable.

224 E.g., VitTinahopf, op. cit. supta note 222 , at $91 \mathrm{ff}$.

225 Hirsch peld, Die Kapitolinischen Fasten, 9 Hermes 93 (1875): Die Kapitolinischen Consularfasten sind keine Ehrendenkmäler, sondern ein historisches Dokument: wollte man eine vollständige Eponymenliste herstellen, so mussten auch diejenigen Männer, die geächtet waren, darin eine Stelle finden. On p. 93 he does consider the conceivability (denkbar) of omission. Compare Mommsen's reply in the same volume, Die Capitolinischen Magistraturtafeln, 273ff.

226 Cicrero, Pro Sestro 14.33: eidemque consules, si appellandi sunt consules quos nemo est quin non modo ex memoria sed etiam ex fastis evellendos putet. 
out. ${ }^{227}$ Mommsen remarks that this remained a frommer Wunsch, a "pious wish."228 This is true but it is not all. Three things may be deduced. First, as early as then, a quarter of a century before the suppression of Marc Antony, the possibility of such a procedure was at least in people's minds, whether or not it was in that epoch ever carried into practice. ${ }^{229}$ Secondly, it was clearly realized that expunction from the fasti went beyond expunction from memory: "torn out not only from memory but also from the fasti." Indeed, this way of putting it suggests that the more radical idea was rather novel at the time. Thirdly, the Orwellian effect of such reality control did not escape Cicero. On erasure, these men would never have held their rank: "if they are to be called consuls who should be torn out from the fasti."230 One is strongly reminded of the rewriting in 1984 of a piece in praise of Comrade Withers after he has become an "unperson."231 Mommsen, incidentally, did perceive that men might want to make an impact on the past. In discussing the rescission of decrees, which can rarely be carried out in full, he observes: "It is simply impossible to make what has happened unhappened; and if political passion refuses to recognize this, the practical conduct of affairs will bring it back to it with absolute inevitability."232 (I do not know whether anybody has made a study of how much and which portions of Hitler's, Mussolini's, Stalin's new order survived the author's disgrace. I daresay the - very substantial - remnants might be divided into three kinds: such as it is practically impossible to get rid of - Mommsen's case; such as one has to concede are worth preserving; and such as, though unworthy, there is not the will to get rid of.)

It would be instructive to investigate Cicero's handlings of unpleasant occurrences in general. For instance, he regrets that a good man's downfall cannot be dismissed from memory; ${ }^{233}$ he is sure - in the lifetime of Marc Antony - that even if the senate revoked all decrees and judgments against him, the memory of his crimes would live on; ${ }^{234}$ he proposes to a friend that

\footnotetext{
22t Gardner, Grarro, Pro Sbstio and In Vatinium 77 (Loeb Classical Library, 1958). en Römischiss Stantsrecht vol. 3, pt. 2 (1888), 1191.

220 Vitrunoropr, op. cit. supra note 222 , at 24 , suspects that it was; I incline to think it was not.

230 Even at an earlier point in the speech, 7.17, Cicero pretends to hesitation to call them consuls, this time because of their treasonable activities - which are, of course, the reason they ought to vanish from the fasti.

231 Orwbll, op. cit. supra note 209. I have seen a painting of a congress with a head which had once been there taken off: that man was not at the congress.

292 Mommsen, Römisches Stantsrecht vol. 2, pt. 2 (3rd ed., 1887) 1132: Geschehenes ungeschehen zu machen ist eben nicht möglich; und wenn die politische Leidenschaft dias nicht gelten lassen will, führt die praktische Handhabung der Geschäfte sie mit zwingender Notwendigkeit darauf zurīck.

$23 s$ Gragro, Pro Prancto 70.

234 Grarro, Pymuppics 12.5.12f.
} 
certain misunderstandings be wiped out from all their memory and lives; ${ }^{235}$ and he declares that the sad time when he was on hostile terms with Caesar, though he cannot erase it from rerum natura, the realm of reality, yet he will erase it from his animus, heart. ${ }^{236}$ Doubtless he knew that one can only approximate an enemy's retrospective degradation or annihilation, not achieve it. His language in regard to expunction from the fast $i$ is all the more remarkable.

I am convinced that Hellenistic-Oriental influences are responsible for the removal of names from inscriptions and fasti. In the East this kind of thing went on from very early times. ${ }^{237}$. The book, or book of remembrance, in which, according to the Old Testament, God inscribes those acceptable and from which he blots out those unacceptable may well be conceived in analogy to customs at earthly courts. ${ }^{238}$ (Commentators seem to think of this book as quite in vacuo. Moreover they fail to appreciate its full significance; to be blotted out, for example, means no more — they assume - than to be prevented from reaching the normal span of life.) ${ }^{239}$ The destruction of a person's or group's memory is common: "I will utterly put out the remembrance of Amalek from under heaven."240 (A modern specimen of a wish for the abolition of a person's memory - the wisher's own - is met in C.P. Snow's The Light and The Dark: '“ 'I hate myself,' said Roy. 'I've brought unhappiness to everyone I've known. It would have been better if I'd never lived. I should be wiped out so that everyone could forget me." ") ${ }^{241}$ The Oriental inspiration of the actions following Marc Antony's death is confirmed by the fact that even the names of other members of his clan were erased, a collective annihilation unique in Roman history but familiar in the East. ${ }^{242}$ Considering that his association with an Egyptian woman was a major cause of the resentment against him, it is ironical that here for the first time at Rome (or at least pretty much the first time) the authorities resorted to punitive steps ultimately, it looks, deriving from Egypt.: Augustus had the excisions from the fasti restored, and indeed both he and Tiberius made it clear that there should be no meddling with the fasti.243. Maybe

235 Cicero, Épistulae ad Familiares 5.8.3.

236 Gicero, De provingirs consularibus 18.43. The relation between forgiving and forgetting is as intricate as important. Two propositions for debate: women forgive but don't forget; old men forget but don't forgive.

237 Examples are cited by Vitringhoff, op. cit. supra note $22 \dot{2}$, at $18 \mathrm{f}$. He leaves the question of influence open: 25. How far these Oriental excisions were designed to interfere with the past I shall not here examine.

238 Exodus 32.32f., Isaiah 4.3, Malachi 3.16, Psalms 69.28, Daniel 12.1.

239 E.g., Coert Rylaardsdam, The Book of Exodus, in 1 The Interpreter's Bible $1069 f$. (1952); Notr, Exonvs 251 (trans. by Bowden, 1962).

240 Exodus 17.1.

241 Penguin edition, 243 (III The Last Attempt, 28 Self-Hatred).

242 See Mommsen, 9 Hermes 276; Vittinomoff op, cit. supra note 222, at $21 \mathrm{ff}$.

243 Vittinghof, loc. cit. supra, n. 242. 
their motive was not only clemency or a conciliatory purpose or consideration for the practical use of the fasti, but also disapprobation of irrational foreign ideas.

21. Recognition of Freeborn Citizen Wrongfully Kept Down.--In the Ropublic you could free a slave, but there was no one who could make him freeborn. To be sure, already in that period, there was room for circumventing the limitation. It happened that a person, though in truth free, was mistakenly treated as a slave, a bona fide serviens; say, he was kidnapped and sold. The comedies of Plautus are full of men and, above all, women in this condition. In such a case there might be litigation, when the judge would decide that the person was free and indeed freeborn; and let us note that even if the person was already "manumitted" by his supposed master, he might want a verdict recognizing his status - he was not a freedman, with all the disabilities that that implied, he was freeborn. ${ }^{244}$ So far so good. But suppose now that it was a question of a person in reality a slave or a freedman, yet the judge was misled or even deliberately found in favor of his freebornship. We know of collusive procedure in this field in later times; ${ }^{245}$ it is quite conceivable that it took place from very early. Here, evidently, so long as the fraud remained undetected, a person not freeborn would nevertheless achieve that rank.

However, the analysis of the situation would be perfectly rational, with no denial of the past: the jurists saw the facts in much the same light as they are seen today. The late classic Ulpian remarks in this or a similar context that "a matter judged is accepted as the truth," res iudicata pro veritate accipitur. He does not say that it is the truth; it counts as such for purposes of the law. ${ }^{246}$

The Empire brought changes, though they were extremely gradual. From the outset, the "golden rings," symbol of knighthood, might be bestowed on a freedman, who thereby acquired in public life the rights of a freeborn citizen. ${ }^{247}$ It is important to realize, however, that he was not on this account looked on as literally freeborn: ut ingenuus habetur, "he is treated as freeborn,"248 ingenuus intellegitur, "he is considered as freeborn," that is to

244 Compare Institutes 1.41 ; Theophilus 1.4 .1 ; Codex 7.14 .4 , Diocletian and Maximian, A.D. 293.

245 See Mayer-Maly, Collusio im Zivilprozess, 71 Zeitschript der Saviony-STiptuno (1954) (Roman section) 264ff., Daube, Zur Palingenesie einiger Klassikerfragmente, 76 Zeitschrift (1959) $254 f$.

246 Droest 1.5.25, 50.17.207, I ad legem Juliam et Papiam. Compare his sober observation on a judgment concerning paternity in Digest 25.3.1.16, $3 \mathrm{pr} ., . X X X I V$ ad edictum.

247 Mommsen, Römisches StaAtsrecht vol. 2, pt. 2 (3rd ed., 1887) 892ff., vol. 3, pt. 1, 3rd ed., 1887, 517ff., Duff, Freedmen in the Early Roman Empire (1928) 86ff., 214ff. On the whole I follow Duff, but on several points I differ from him as well as from Mommsen.

248 Diagst 40.10.5, Paul IX ad legem Juliam et Papiam. 
say, for certain purposes 249 - that is all. Actually, in private life his position remained legally inferior: his former master retained all privileges of a patron, and above all some hold on the inheritance. (I am disregarding voluntary arrangements by which a patron could give up his claims.) Vivit quasi ingenuus, moritur quasi libertus, "he lives as one freeborn, he dies as a freedman."250 Until the reign of Commodus ${ }^{251}$ it is still true to say that it was not possible to turn one not freeborn into one freeborn with such effect that ingenuus fit, "he becomes freeborn." 252

Let us look at some relevant incidents. Augustus admitted only freeborn guests to formal dinners - with the exception, Suetonius tells us, of Menas, a Greek, who had once been a freedman admiral of Sextus Pompey's, but had gone over to Augustus. Even he, Suetonius adds, was invited only after a judgment that he was freeborn. ${ }^{253}$ Asserere in ingenuitatem, "to assert into freebornship," is technical of the appropriate trial, ${ }^{254}$ and it is quite wrong to treat this term as implying an imperial grant.255 Maybe the evidence was not scrutinized too carefully. But we must not rule out the chance ${ }^{256}$ that he was really freeborn and had been carried off and sold by gangsters or pirates. The risk of such capture is a recurrent theme in the historians of the early Empire; ${ }^{257}$ and the fact that stories of this sort figure prominently

249 Dionst 40.10.6, Ulpian I ad legem Juliam et Papiam, with reference to a rescript by Hadrian.

230 Digest 38.2.3, Ulpian XI ad edictum. Mommsen thinks that this was not always so. But his evidence is weak. He refers to Pliny, EpIstres 8.6.4, where the senate is reported as voting that Pallas, a freedman of Claudius, should be not only entreated but compelled to wear "the golden rings." Mommsen argues that Pallas refused "the rings" in order to keep Claudius as patron - ergo he would have lost him had he accepted them. The text, however, contains no hint at this specific motivation; Pallas is depicted as of a general fake humility - he also refused money voted to him by the senate. In fact, whereas in the end he did accept "the rings," he never took the money (EPISTLEs 7.29.1, 8.6.1, 8ff.). Mommsen is probably influenced by TAcitus, Annals 12.53.3, where the senate thanks Pallas for consenting to remain among the ministri, "servants," of Claudius. The splendid thing Pallas does, however, is to continue in the public offices (usui publico, "for the welfare of the State") reserved for freedmen. The matter of a patron's private rights is certainly not in the senators' minds. Not to mention the fact that this passage is quite unconnected with Pallas's refusal of "the rings": it contemplates a judicial recognition of freebornship he might have gained - see infra, p. 60. Admittedly, if it were recognized that he had never been a slave, only believed to be one, he would have no patron; but this has nothing to do with "the rings."

251 Or possibly the close of that of Marcus Aurelius: see infra, note 294, on Drosst 40.11.3, Scaevola VI responsorum.

252 See infra, p. 68, on Digest 40.11.2, Marcian I institutionum.

253 Suetonius, Augustus 74.

254 Compare infra, p. 61 , on Suetonius, Vespasian 3 ; also Suetonius, Tiberius 2.2, referring to the wicked decemvir who attempted "to assert a freeborn virgin into slavery," virginem ingenuam in servitutem asserere.

285 This is done by Dupf, op. cit. supra note 247 , at 87.

256 As is done by Momisen, op. cit: rupra note 247, vol. 2, pt. 2, at 893, vol. 3, pt. 1, at 519 .

257 E.g., Suetonius, Augustus 32 ; Tiberius 8. 
in the fraudulent claims to freebornship retailed in the sources 258 is additional proof that the thing did occur - otherwise it would have been no use as a story. In his treatise On Grammarians Suetonius has a chapter on Gnipho, whom Cicero is said to have respected: he was born, we learn, in Gaul of free parents, ingenuus natus, but cast out, expositus, though his foster father set him free, a nutritore manumissus. 259

Dio's comment on the elevation of Menas is different: Augustus gave him "the golden rings," thus lifting him above the condition of a freedman. ${ }^{260}$ That Menas received "the rings" is not unlikely. But in confining himself to the mention of this distinction Dio is influenced by the less rigorous notions prevalent in his era. For Augustus, that would not have been enough; if it had been, there would be no point in the notice that he entertained only freeborn guests - he could simply have conferred "the rings" on anyone he fancied. Suetonius, who on this occasion names his source, Valerius Messala Corvinus, a contemporary of the events in question, is clearly right: the decisive factor in Menas's inclusion among the freeborn was the finding of the judge, honest or dishonest, that he was in fact entitled to it.

Appian, though simplifying somewhat, furnishes corroboration: Augustus "declared Menodorus (Menas) free (freeborn) from being a freedman."261 This basically coincides with Suetonius: in accordance with the Emperor's wishes it was established that Menas was freeborn. White's rendering, Augustus "made" him freeborn, may be good English but is not exact.262 To "make" a freedman freeborn was not - not yet - feasible. The Greek is apephenen, "declared," in the sense of "had him declared," or "found," freeborn.

Nero had a hand in two dubious promotions to freebornship. A favorite actor of his, who had been a slave of his aunt Domitia and had bought his freedom from her, with the help of the Emperor's influence succeeded in recovering the money - on the ground that he had been a bona fide serviens, a free person erroneously kept as a slave. ${ }^{263}$ Whether, as is generally assumed, ${ }^{264}$ there were two trials, the first to get his status recognized and the second to recover the money, or whether, as is also thinkable, there was only one, about the money, which implicitly settled the question of status as well,

258 See Mayer-Maly, op. cit. supra note 245.

259 Suetonius, De Grammaticis 7. This may again be invention; even as such it would indicate the range of what-might occur.

260 Dro 48.45 .7ff.

261 Bella crvilia 5.80. Appian, like Suetonius, used the work of Valerius Messala Corvinus: see Hanslik, Paulys Realencyclopädie der Chassischen AltertumsWISSENSCHAFT vol. VIIA (1955), 156.

262 Appian's Roman History 513 (Loeb. Classical Library, vol. 4 [1961]).

263 Tagrtus, Annals 13.19, 27; Digest 12.4.3.5, Ulpian XXVI ad edictum.

264 Annals 13.27 favors this alternative. See, e.g., Boyé, Pro Petronia Iusta, Mélanges LÉvY-BRUHL 32 (1959). 
is immaterial here. In either case it was the verdict of a court which, with whatever degree of partiality, established his free birth. A conferment of "the rings" would not have served. It did not make a freedman freeborn; it left the former master's position intact, and Domitia could have kept her money.

Then there was Acte, whom Nero for a time thought of marrying, in full matrimonium iustum. According to Suetonius she was just an Asian freedwoman, but Nero bribed high dignitaries to swear that she was regio genere orta, "offspring of a royal house." 265 That is to say, she or, say, her mother had been abducted and illegally reduced to a servile condition. This account, then, with the oath of witnesses purchased, clearly makes Nero procure a judicial pronouncement concerning her status. Claudius's freedman Pallas, in the view of the flattering senate, could also have obtained a judgment establishing his free birth: he too was (gave himself out as) of old royal descent. Only he was so selfless as to prefer to remain an imperial freedman and perform the functions appropriate to this rank. ${ }^{266}$

Dio says that esechthe into the house of Attalus. ${ }^{267}$ This is capable of various interpretations. It may mean that "she was assigned" to that royal house, in the sense in which Suetonius represents Nero as foisting her on it, by means of a fraudulent trial. Some authorities, however, translate "she was adopted."268 That would have been a different method, not a judgment confirming her noble provenance, but a covering up of her servile birth by incorporating her in a great family. It is possible that Nero considered or even resorted to both devices, adoption as well as a trial concerning her status. ${ }^{269}$ At all events, neither Suetonius nor Dio is speaking of a grant of freebornship.

Of Vespasian's wife Suetonius tells us ${ }^{270}$ that, prior to her marriage, she was found freeborn and a Roman citizen by a court. As for her citizenship, she was a native of Ferentum, hence a Latin by birth. Her father, however,

265 SUETONIUS, Nero 28.1.

266 Tacitus, Annals 12.53.3; see supra, note 250.

287 Dio 61.7.1.

268 E.g., Cary, Dio's Roman History 41 (Loeb Classical Library, vol. 8 [1961]).

269 Far be it from me to enter into the problems arising if we think of adoption. The first question is whether there was a suitable Attalid around to adopt her; Ronald Syme assures me that there was. But then, as it was presumably a case of arrogation, could a woman be arrogated? Could a freedman (freedwoman) be arrogated with all the legal effects Nero desired? I shall not say a word - except this, that the violent statement of Sabinus transmitted by GeLlius 5.19 .12 may have been directed against precisely this scheme of Nero's: "But this is neither permitted nor ever to be permitted, that persons of the condition of freedmen should invade the rights of the freeborn." If this is an antiNeronian utterance, it was hardly made under Nero. We know that Sabinus lived to comment on the senatusconsult Neronianum of 64 B.C. Nero died in 68 . Sabinus could still have lived.

270 Suetonius, Vespasian 3. 
was elected to some municipal office, which apparently in the court's view entitled him and his descendents to Roman citizenship. ${ }^{271}$ To be sure, from Suetonius's language it may be gathered that the particular office he occupied was not normally sufficient to ground Roman citizenship. A municipal quaestor would be high enough, ${ }^{272}$ but her father, Suetonius says, "was nothing more than a quaestor's clerk." Whether the court let it go at that or whether it assumed (rightly or wrongly) that he had risen higher it is impossible to decide.

Now we come to the part of the verdict recognizing her as freeborn. Why had this fact to be confirmed? Maybe the form of a trial to establish citizenship routinewise included the question of ingenuitas; or maybe Vespasian wished it confirmed from general caution. But I could also think of a more specific reason. The lady had been another man's delicata. Such a position was often held by a slave or freedwoman. It may, therefore, have been advisable to prevent any untoward suspicions. It is noteworthy that it was her father who performed the requisite asserere, "asserting," in the trial: 273 that would show that there was nothing to hide. The relevant deduction is that the story contains no vestige of a grant of freebornship: a person actually freeborn has the fact established by a judgment. ${ }^{274}$

A letter of the younger Pliny to Trajan has been seriously misconstrued.275 Pliny was administering Bithynia as Trajan's legate, through ordinarily this province would have been under a proconsul; and in view of a certain senatusconsult he was doubtful whether, not being a proconsul, he had the right to sit de agnoscendis liberis restituendisque natalibus, "in cases concerning children to be acknowledged and birth to be restored." This means litigation about paternity and freebornship - litigation, that is, as to whether or not, in certain circumstances, a man has to acknowledge a child as his, ${ }^{276}$ or as to whether or not a man, hitherto considered a slave or a freedman, may have his free birth established. Literally, it is "birth" without "free," or even more literally, "native conditions": natales. The point is that only free birth is birth, a slave has no birth, no native conditions - a bit as, in English,

271 See, e.g., Gayus 1.96 .

272 E.g., STRabo 4.1.12.186f.

273 See supra, p. 58.

274 Very misleading, therefore, is the account of Stein, Flavia Domitilla, Paulys RenLENCYCLOPÄpIE vol. 6 (1909) 2731, who writes that Roman citizenship was zuerkannt, "assigned," to her after her trial. Not to mention his description of the trial as a Freiheitsprozess, as if it had been a question of her freedom. Schmidis, DAs RekuperatorENVERPAHREN 90f. (1963), like Stein, expresses himself as if the procedure had been one by which she became a citizen (Bürgerrechtsverleihung, sie sollte römische Vollbürgerin werden). At least, however, he clearly represents her as of free Latin birth. Fortunately, the error has no bearing on the main propositions of his book.

275 Puny, Epistles 10.72; Trajan's reply in 10.73.

276 See title 25.3 of the Drozst. 
only a gentleman has a gens, a family. ${ }^{277}$ The addition of mei, tui, sui to natales, incidentally, is not uncommon: ${ }^{278}$ it is a question of the birth, the native conditions, of the individual concerned, "my," "your," "his" birth. 279

The current interpretation is that Pliny is thinking of a grant of freebornship to persons of servile birth. ${ }^{280}$ This is an anachronism; as already indicated, it was not before Commodus, some seventy-five years after Trajan, that a man of servile birth might be directly, openly turned into one of free birth. And it was in consequence of this innovation that natales suos restituere, "to restore an individual's free birth," came to denote "to confer free birth on one not freeborn." I shall of course say more about this:

That Pliny has in mind, not a grant of freebornship, but a judicial pronouncement on a man's status at birth is obvious. First, there is the pairing off of this procedure with that concerning paternity - surely not a grant of paternity (in most cases the man does not want to be the father) but a lawsuit to end in a finding. ${ }^{281}$ In fact there is a definite link between the two procedures: the result of that concerning paternity is likely to bear on a later one concerning status. Secondly, Pliny asks whether he might cognoscere, in these matters: "find," not "make grants."282 Thirdly, when, considerably later, the grant of freebornship to persons of servile birth became customary, it always remained the prerogative of the Emperor; it was never within a proconsul's competence. Yet Pliny reports to Trajan that people press him to deal with these cases secundum exempla proconsulum, "according to the practice of proconsuls."

The picture resulting from the interpretation here combated is indeed astonishing - proconsuls regularly receiving requests from slaves or freedmen to endow them with freebornship and making or declining the grant. One asks oneself what makes modern commentators thus fasten on the secondary sense of natales suos restituere. I suppose one factor is that the original, literal sense in which Pliny still employs the expression is not mentioned by Mommsen. 283 The initial error has produced some major consequential ones;

277 Martul 10.27.4 tells the freedman Diodorus that, notwithstanding his sumptuous birthday celebration, nemo tamen natum te putat, "nobody believes you born"; see Durr, op. cit. supra note 247 , at 68 and $86 f$.

278 E.g., de natalibus suis restituendis in Trajan's reply, Pliny 10.73, natales tui in Codex 4.19.10, Diocletian and Maximian, A.D. 293.

279 See, however, infra, p. 69, on Digest 40.11.2, Marcian $I$ institutionum.

280 E.g., Melmoth, Pliny, Letters 372 (Loeb Classical Library, vol. 2, [1963]).

281 The term agnoscere, incidentally, "to acknowledge," conspicuous in connection with paternity, is also applied to the "acknowledgment" of an apparent freedman's true, free origin: Digest 40.14.3 pr., Pomponius $V$ senatus consultorum (for the understanding of which passage it is useful to consult Codex 7.14.1, Alexander, between A.D. 222 and 235).

282 The term recurs in Trajan's reply, 10.73.

280 Mommsen, Römiscees StaAtsRecer vol. 2, pt. 2, 894 (3rd ed., 1887). In fact he does not quote the letter at all - nor does Duff. For another factor making for confusion, see infra, p. 72. 
as when Hardy explains that "the phrase was based on the theory that the original condition of men was one of freedom."284 This is to turn things upside down. At its inception, the phrase was quite pedestrian, referring to the trial by which a freeborn man whose status was denied him regained - or more precisely, had reconfirmed - what was his by virtue of his origin. From Commodus, it signified more and more, though even then never exclusively, ${ }^{285}$ the Emperor's grant of freebornship to a man not freeborn. It was this usage which, we shall see, at the end of the classical era, was brought into relation with, supported by, the doctrine of universal freedom in the golden age. To place the doctrine at the beginning is to credit the rulers of the first and second centuries A.D. with a magnanimous visionary policy of which they were plainly innocent. 288

22. Creation of a Freeborn Citizen by the Emperor. - Under Marcus Aurelius there was a crisis. Difficulties of proof in trials about freebornship were felt to be so awkward that the Emperor ordered registration of freeborn children in both Rome and the provinces. ${ }^{287}$ In the meantime, no doubt, benevolent as he was, he often as a judge pronounced in favor of free birth where the evidence was less than conclusive. It is from the reign of his successor Commodus onwards ${ }^{288}$ that we come across in the texts a grant of freebornship by the Emperor to persons avowedly born in slavery. ${ }^{289}$

The term natales suos restituere henceforth signifies two things. On the one hand, it continues in its original meaning, "to restore a person's free birth, free native conditions," on the other, it now can mean "to confer free birth, free native conditions, on a person of servile birth." If the latter meaning is the more frequent in our sources, that may be simply because it raises more problems, is of greater interest to legal writers, not necessarily because it predominated in actual life. At any rate, the former sense is met, and indeed, the lawyers are fully alive to the difference between the two functions. Naturally, once there was the grant in addition to the judicial finding, the latter, whenever proceeding from the Emperor, must assume some of the former's coloring. Even so, Ulpian transmits the decision that if a person is "restored to his free birth" by the Emperor on the strength of a false affirmation of free

284 Quoted by MeLmoth, op. cit. supra note 280, at 372 .

285 See, e.g., infra, 63f., on Digest 40.11.1, Ulpian 11 responsorum.

286 Leist, Das römische Patronatsrecht, pt. 2, in Glücx, AuSführliche ErLäuteruno Der Pandecten, Serie der Bücher 37/8 pt. 5 (1879) 311f., comes nearer the correct evolution of the meanings of the phrase.

287 Julius Capitolinus, Marcus Antoninus (Historu Augusta) 9.7ff.

288 Conceivably from the end of that of Marcus Aurelius himself : see infra note 294.

289 How this innovation is connected with the change in the "right of the golden rings," which (if MOMMSEN is right, op. cit. supra note 283, at $893 \mathrm{f}$.) from Commodus no longer implied a knighthood, I shall not here investigate; see, however, infra, p. 71, note 315 . 
birth, the act is vitiated.290 This is plainly a "restoring" in the sense of judicial or quasi-judicial establishment of the status to which, if he is telling the truth, the man is entitled.291 By contrast, the new natales suos restituere by way of a grant is designed precisely for a man whose servile birth is admitted. 292

How was this grant construed? How was this correction of a man's origin by means of imperial privilege viewed? Inevitably a large element of fiction, of "as if," of conscious treatment of $\mathrm{x}$ as $\mathrm{y}$, always remained. But in quite a few texts we can discern also something of an assumption that, supernaturally, the man was indeed changed. In some cases of legal personality, however different the historical background, we might come across parallels, but I shall not enlarge on them. One ought to remember, however, the enormous claims of certain Emperors, Commodus among them, who thought of Rome as his foundation, colonia Commodiana. ${ }^{293}$

The earliest comment we have is from Scaevola. ${ }^{294} \mathrm{He}$ is relatively cautious. Consulted as to whether a man whom the Emperor "has restored to his free birth" enjoys ingenuitatis ius, "the right of freebornship," he lays down

290 Droest 40.11.1, Ulpian $I I$ responsorum. Instead of "to restore an individual's free birth," natales suos restituere, it is not unusual to say "to restore an individual to his free birth," natalibus suis restituere; e.g., Digest 40.11.3, Scaevola VI responsorum, with reference to a grant of freebornship. The passive designation "restored to free birth" recurs in Codex 6.8.2, Diocletian and Maximian, A.D. 294, also concerned with a grant. The nominal phrase natalium restitutio, "restoration of free birth," does not seem to be in use before Justinian: see infra, p. 72.

291 In Codex Theodosianus 15.14.4, Constantine, A.D. 326, the senate is to judge about the reinstatement of such as contend that they were arbitrarily degraded by Constantine's rival Licinius and wish natalibus suis restitui, "to be restored to their native conditions." In Codex Thzodosinus 5.8.1, Constantine, A.D. 314, natalibus suis restituere signifies the factual, extrajudicial restoring of a person to his position of a freeborn citizen of which he was wrongfully deprived under Constantine's rival Maxentius.

292 Natales redere, "to return free birth," is synonymous with natales restituere. The passive designation natalibus redditus, "returned to free birth," implies a grant of freebornship in Digest 39.2.3.1, Ulpian XII ad edictum. In a much later text, Codex 8.50.13, Diocletian and Maximian, A.D. 294, natales pristinos reddere, "to return the pristine free birth," means the recognition of a true free birth. So does ingenuitati suae reddere, "to return somebody to his freebornship," in CoDex 7.14.4, Diocletian and Maximian, A.D. 293. In the Interpretatio ad Codex Theodosianus 5.8.1 (see the preceding footnote) ingenuitati reddere signifies the extrajudicial handing back of a man to his freeborn position. In Novella Maioriani 7.5, A.D. 458, natalibus suis reddere signifies the extrajudicial handing back of a decurion's (municipal councillor's) daughter to the oppressive native dignity.

293 Aelius Lampridius, Commodus Antonius '(Historia Augusta) 8.6ff., Dro 72.15.2; compare Pharaoh's boast "Mine is the Nile and I have made it," Ezechiel 29.3,9.

204 Digest 40.11.3, VI responsorum. If Scaevola was no longer alive or active under Commodus, this opinion must go back to the previous reign; I prefer a date under Commodus, but there is no evidence. Respondit: quaeris an ingenuitatis iure utatur is quem sanctissimus et nobilissimus imperator natalibus suis restituit. sed ea res nec dubitationem habet nec umquam habuit, quin exploratum sit ad omnem ingenuitatis statum restitui eum qui isto beneficio principis utatur. "He replied: You ask whether he whom the most sacred and noble Emperor has restored to his native conditions enjoys the right of freebornship. But this point neither suffers nor has ever suffered any doubt, that it is established that he who enjoys that imperial privilege is restored to the complete status of freebornship." 
that the recipient of this beneficium, "privilege," ad omnem ingenuitatis statum restitui eum, "is indeed restored to the complete status of freebornship." The consultation itself shows that natales restituere by way of a privilege, beneficium, is a novelty at this moment, with effects not yet universally familiar. Scaevola's construction is just within the boundaries of the rational: "the complete status of freebornship" need imply no more than treatment by the law of a person not freeborn as one freeborn, full concession to an outsider of the legal position normally reserved for a group. Where Scaevola exaggerates is in maintaining that the extent of the grantee's rights is so obvious that the questioner need not have asked at all: "But" has ever suffered any doubt, that it is established that he is restored to the complete status of freebornship." Such overemphasis is common precisely where serious doubts did or do exist but cannot be admitted; that is to say, it is not enough to refute them or declare them groundless, their very existence must be denied. Gaius uses the same method when he asserts: "nor has it ever been doubted that a decree of the Emperor has the force of a statute."296 In Stalin's last years, it was not doubted, nor had there ever been any doubt, that he was the man by whom Lenin wanted to be succeeded. The Preamble to the Constitution of Ghana, 1960, says: "We the People of Ghana . . . in exercise of our undoubted right to appoint for ourselves the means whereby we shall be governed . . ..."

Schulz declares 40.11 .3 "a text assuredly postclassical both in form and substance": it does not show Scaevola's usual division into facts, question and reply, it is theoretical instead of dealing with a specific practical case, and question and reply are both unintelligible. ${ }^{297}$ I admit that the original is. shortened, probably in order to achieve what Schulz calls "theory," generalization. With this reservation, the responsum fits the state of law in Scaevola's later years better than any other period. As for unintelligibility, I hope I have removed that.

According to Ulpian, a freedman who receives "the golden rings" still owes reverence to his patron though he may occupy omnia ingenuitatis munia, "all public offices of freebornship"; but if he is "restored to free birth, free native conditions," the duty is gone since princeps ingenuum facit, "the

295 This "but" itself characterizes the question as unnecessary.

296 GaIUS 1.5: nec umquam dubitatum est quin id (constitutio principis) legis vicem optineat. I wish HONORÉ were right in suggesting (op. cit. supra note 41, at 118ff.) that Gaius is here ironical.

207 Schulz, Uberlieferungsgeschichte der Responsa des Cervidius Scaevola, in SYMBOLAx Friburgenses in honorem Ottonis Lenel 159f., 169 (1933). Levy seems to concur: Libertas und Civitas, 78 Zeitschrift der Savigny-Stiptung (1961) (Roman section), 170. 
Emperor makes a freeborn man."298 That this opinion has regard, not to the judicial recognition of a true ingenuus, but to the privilege discussed by Scaevola, the grant of ingenuitas to one not in truth freeborn, is certain: the whole problem can arise only in the latter case. (The same consideration applies to the further texts I am going to inspect.) Ulpian, however, goes beyond Scaevola's "complete status of freebornship": the beneficiary now becomes freeborn.

A freak formulation? The further development shows that it is not that. Towards the end of the third century A.D. the Emperors Diocletian and Maximian distinguish: whereas "the golden rings" confer on the grantees libertinitatis quoad vivunt imaginem, non statum ingenuitatis, "while they live, the appearance of freedmanship, not the status of freebornship" (i.e., when they die their patrons have claims to the estate), ${ }^{299}$ natalibus antiquis restituti liberti ingenui constituuntur, "those freedmen who are restored to past free birth are created freeborn citizens."300 The "status of freebornship" here means that the person has been made freeborn.

A much-favored emendation of a statement by Modestinus now turns out to be unwarranted. Modestinus, a pupil of Ulpian's, writes as follows: "A freedman who is restored to free birth is considered as if, being made freeborn, he had not in the meantime suffered the blemish of slavery.'301 He accepts the notion that the person is made freeborn, and he concludes that the degrading life in slavery is regarded as not having occurred. Fullest consistency would perhaps have required the denial of any medium tempus, "meantime," between birth and now. In strictness, that is, since the person is made freeborn, there is no "as if" at all, the blemish should not only be regarded as not having been, it just has not been. I have already remarked, however, that

298 Digest 2.4.10.3, Ulpian $V$ ad edictum (compare 6.4.3, Justiniañ, A.D. 529). Sed si ius anulorum accepit, puto eum reverentiam patrono exhibere debere quamvis omnia ingenuitatis munia habet. Aliud si natalibus sit restitutus: nam princeps ingenuum facit. "But if he receives the right of the rings, I believe he must display reverence to his patron though he has all the offices of freebornship. It is different if he is restored to free birth, for the Emperor makes a freeborn citizen."

299 Compare Drozst 38.2.3, Ulpian $X L I$ ad edictum, quoted supra, p. 58: "He lives as one freeborn, he dies as a freedman."

300 CoDex 6.8.2, A.D. 294. Aureorum usus anulorum beneficio principali tributus libertinitatis quoad vivunt imaginem non statum ingenuitatis praestat, natalibus autem antiquis restituti liberti ingenui nostro beneficio constituuntur. "The enjoyment of the golden rings assigned by imperial privilege confers while they (the beneficiaries) live the appearance of freedmanship, not the status of freebornship; those freedmen, however, who are restored to past free birth are created freeborn citizens by our privilege." There is much to be said for the emendation by Cujas of libertinitatis into libertinis: "the enjoyment of the golden rings confers on freedmen while they live the appearance, not the status, of freebornship." This would conform to Fracmenta Vaticana 266, Papinian XI questionum, and Codex 9.21.1 pr., Diocletian and Maximian, A.D. 300, with reference to the lex Visellia. My thesis is not affected.

301 Digest 40.11.5.1, VII regularum. Libertinus qui natalibus restitutus est perinde habetur atque si ingenuus factus medio tempore maculam servitutis non sustinuisset. 
in a construction like that before us, which refashions the past, traces of fiction inevitably remain. For Modestinus, the man is made freeborn no fiction here; though, with a slight degree of incongruity, he does represent as a fiction the absence from the man's life of any blemish of slavery.

Haloander, the great sixteenth-century editor of the Corpus Juris, did not appreciate the force of "being made freeborn"; no doubt he also boggled at the lack of logic, the vagueness of medium tempus. His emendation of ingenuus factus into ingenuus natus is recommended by modern editors, Kriegel and Mommsen. We ought to read, then: "A freedman who is restored to free birth is considered as if, being born free, he had not in the meantime suffered the blemish of slavery." One reason modern authorities like the emendation is presumably that they find it easier, on this basis, to make Modestinus adhere to the fictitious character of the free birth: the grantee (they interpret) "is considered as if he were born free and had not in the meantime suffered the blemish of slavery." 302 But rational as this is, it is not what Modestinus says nor what, considering the other texts, we should impute to him. ${ }^{303}$

In the Eastern half of the Empire, it seems, the consequence was drawn that even a child born to a grantee prior to the grant retrospectively gained the higher status. A constitution by Diocletian and Maximian rejects this view. ${ }^{304}$

A highly significant piece of evidence from outside the juristic discussion

302 Haloander's idea seems to have been somewhat different. He certainly kept out the supernatural creation of a freeborn man, but he did so by a more complicated route, namely, by assuming that the text concerns a person in truth freeborn, in truth ingenuus natus. (This was a widespread understanding - misunderstanding - of the text, still shared by Leist, op. cit. supra note 286, at 311, and, who knows, perhaps leading a shadowy life even today.) More precisely, the freedman in question had really been born free, had then fallen into real slavery (say, he was a foreign prisoner of war at Rome or a Roman criminal condemned into the mines), had then been manumitted by his master (not "manumitted" from a supposed slavery but really manumitted) and was now receiving the privilege of free birth. This man "is considered as if, being (in fact) born free, he had not in the meantime (when subsequently enslaved) suffered the blemish of slavery." The grant thus does not make a man not freeborn into one freeborn, it simply produces the fiction that a freeborn man continued free throughout his life. It must be conceded that this interpretation relieves the medium tempus of all difficulty. But there are decisive objections; the grant of natales restituere nowhere else has regard to a person really freeborn. It is incredible that, if this text were an exception, we should be left to read the whole, immense story into it. I would also point out that, if a grant of natales restituere to persons really freeborn and then enslaved had been known, it would have had to be quoted in CoDex 5.4.23.1, Justinian A.D. 520-523, as the closest approximation to the measure proposed in this law; but we find only the usual grant to those of servile provenance. See infra, pp. $75 \mathrm{ff}$.

303 On the fiction "as if he were born free" in Diorst 40.11.2, Marcian I institutionum, and Codex 5.4.23.1, just adverted to (see the preceding footnote), I shall say something presently.

804 Codex 6.55.6, A.D. 294: the probability of an Eastern addressee emerges from Mommsen, Zeitfolge der Verordnungen Diocletians und seiner Mitregenten, Abhandlungen der Kgl. Akademie der Wissenschaften zu Berlin, (1860) 419ff. [Gesammelte Schriften, vol. 2 (Juristische Schriften), 1905, 265ff.]. Ex libera conceptus et servo velut spurius habetur nec ut decurionis filius, quamvis pater eius naturalis manumissus et natalibus suis 
is here to be adduced: the tomb inscriptions of freedmen elevated to freebornship. As pointed out by. Mommsen, ${ }^{305}$ these inscriptions suppress the deceased's quality as a freedman. More than that. In the enumeration of the successive public offices held by the deceased they suppress those indicative of that quality, those normally bestowed on freedmen. This history writing à la 1984 seems to have boen resorted to even in the case of freedmen who merely received "the golden rings" (though, as Mommsen notes, there is no concealment of the servile origin of the tutor of the Emperor Verus). Anyhow, there is here striking confirmation that those references by lawyers to what is not far from a supernatural creation of a citizen of free birth must be taken seriously. On the inscriptions in question, the "meantime," the life of blemish, has simply never been.

23. Creation of a Freeborn Citizen and the Natural Law of the Beginning. - Towards the end of the classical era, the development led to a brilliant theory, sponsored by Marcian, a slightly older contemporary of Modestinus. It aims at rationalization yet introduces a miraculous note of its own. "At times," he explains, "even persons born as slaves are made freeborn ex post facto through intervention of the law, as when a freedman has been restored to his native conditions by the Emperor. For he is restored to those native conditions in which at the beginning all men were, not to those in which he himself is born, since he was born a slave. For such a one is treated with regard to the entire law as if he had been born free, and his patron can lay no claim to his estate. Therefore in general the Emperors do not readily restore anyone to native conditions without his patron's consent."306

Marcian starts by adopting the by then prevalent concept: the grant makes the freedman freeborn, his freebornship is ex post facto effected by the law. But then he goes on to give the matter a new twist. It is not the grantee's own native conditions which are restored to him, but the native conditions of the golden age, before slavery had made its appearance.

This doctrine has considerable advantages. We have seen that, linguistically, the term natales restituere, "to restore native conditions, birth, free birth," goes back to the trial by which a man in truth freeborn but somehow

restitutus hunc fuit adeptus honorem, defendi potest. "A child conceived by a free woman with a slave is treated as spurious and it cannot be pleaded that he is a decurion's son, even though his natural father, manumitted and restored to his native conditions, has attained this honor."

30s Mommsen, Römisches Staatsrecht vol. 3, pt. 1, $518 \mathrm{f}$.

306 Drgest 40.11.2, I institutionum. Interdum et servi nati ex post facto iuris interventu ingenui funt, ut ecce si libertinus a principe natalibus suis restitutus fuerit. illis enim utique natalibus restituitur in quibus initio omnes homines fuerunt, non in quibus ipse nascitur cum servus natus esset. hic enim quantum ad totum ius pertinet perinde habetur atque si ingenuus natus esset, nec patronus eius potest ad successionem venire. ideoque imperatores non facile solent quemquam natalibus restituere nisi consentiente patrono. 
kept out of his rights recovers them. In the latter half of the second century A.D. there was introduced the bestowal of freebornship on persons admittedly not in truth freeborn. The term "to restore native conditions" was extended to this case, which, manifestly, it does not fit. There is here no restoration; there is creation, a grant. Marcian's theory does away with this awkwardness. According to him, there is indeed restoration - namely, of the ideal, primeval state of things, the position the person would have held but for the degeneration of mankind. Where he or other exponents of this doctrine still speak of a restoring of natales sui, "his native conditions, his free birth," instead of simply natales, "native conditions, free birth," we should paraphrase not "his individual free birth," but "the free birth ideally his as a member of the pure human race."307

A further, substantive merit of the doctrine is that it removes the need to deny the facts. The servile birth of the individual concerned can be conceded, and Marcian stresses the point: "since he was born a slave." It can be conceded seeing that what is granted is not a free birth of his own but the abstract free birth which once belonged to all men. He is freeborn in the sense of being elevated above the unnatural division of mankind. As for his servile origin in this divided society, that, in consequence of his elevation, ceases to count. But, as just remarked, it is not suppressed. Marcian at this point definitely assumes a fiction: the person, he says, "is treated as if he were born free."

While these are advances in the direction of a rational definition, the supernatural element is far from eliminated. This privileged placing of the beneficiary into the order of an uncorrupted world is also a conquest of time, though perhaps less crude than endowment with a new, personal free birth. He is still, as already observed, actually turned into a freeborn citizen: "persons born as slaves are made freeborn." Only he is made freeborn not so as to be born free in this life, but so as to participate in the universal free nativity of the golden age. As for this life, the law, in pursuance of his restitution to the pristine, ideal world, feigns him to be of free birth. That restitution is real; the Emperor even in this doctrine has power ex post facto to elevate the man's past.

The original, free state of all under natural law is repeatedly affirmed by the later classics. ${ }^{308}$ A passage in Justinian's Institutes is reminiscent of Marcian's wording: "For by natural law, at the beginning, all men were

307 Cf. supra, p. 62.

308 Digrst 1.1.4, Ulpian $I$ institutionum, 1.5.4.1, Florentinus $I X$ institutionum, 12.6.64, Tryphoninus VII disputationum, 50.17.32, Ulpian XLIII ad Sabinum; see Levy, op. cit. supre note 33 , at $12 \mathrm{ff}$. 
born free."309 According to Voigt and Kalb,310 it is indeed taken from Marcian, while Ferrini doubtfully suggests Florentinus as its source. ${ }^{311} I$ incline to the former alternative: Marcian was an institutional writer whose new ideas greatly appealed to Justinian. ${ }^{312}$

There is, however, a possibility which, remote though it is, should not be passed over - that the linking of the grant with the golden age transmitted under the name of Marcian is an interpolation, maybe by the compilers themselves. Albertario and Beseler thought so.313 I believe it most unlikely. Still, the theory propounded by the fragment would lose none of its interest.

24. Creation of a Freeborn Citizen and Legitimation by Rescript. - What is certain is that Justinian was greatly attracted by this theory. In A.D. 538 he introduced a fresh mode of legitimation, to wit, by imperial rescript; and he expressly represented this innovation as modelled on the creation of a freeborn citizen: "For just as there is a mode invented by those before us which leads freedmen to freebornship, first cleansing them by another act and giving them the right of the golden rings, then restoring them to nature itself which at the beginning did not distinguish slave and free but made the offspring of man free, so we too intend the same for the matter in hand."314 He goes on to say that originally there was no division into legitimate and bastard children; there were only legitimate ones. Wars produced slavery; excessive desire, bastardy. The passions involved in both are the same; hence the remedy should be the same: what his predecessors thought out to deal with slavery, a grant from the Emperor, he is now extending to bastardy.

That the grant of freebornship is here conceived in supernatural terms is evident, if only from the reference to purification. According to Justinian, prior to the grant, the candidate is cleansed by means of the "golden rings,"

309 INSTTUTES 1.2.2, iure enim naturali ab initio omnes homines liberi nascebantur.

s1o Voigt, Die Lehre vom jus Naturale, vol. 1 (1856) 332, 566ff.; Kalb quoted by Ferrini: see the following footnote.

311 Ferrini, 2 Opere 331f. [13 Bullettino 123f.]

812 Buckland, Marcian, Studi RrcсовоNo, vol. 1, 1936, 277ff. This is not to maintain that the whole of INSTitutes 1.2 .2 rests on Marcian.

313 Albertario, Concetto Classico e Definizioni Postclassiche del Ius Naturale, Studi, vol. 5 (1937) 288 [equals 57 Rendiconti del Reale Istituto Lombardo di Scienze e LetTERE (1924) 178]; Beseler, Unklassische Wörter, 56 ZeItschrift der Savigny-Stiftung (1936) Rom. Abt., 66. The offending word which the latter is presenting in this section of his article is ecce. He reconstructs the text as follows: [-] si libertinus a principe natalibus suis restitutus fuerit [-], perinde habetur atque si ingenuus natus esset nec patronus eius <heres fieri bonorumve eius possessionem accipere> potest [-]. "If a free man has been restored to his conditions by the Emperor, he is treated as if he had been born free, and his patron cannot become his heir or take his goods by way of bonorum possessio."

314 Novella 74.1: hosper gar este tis tois pro hemon exeuremenos tropos hos tous apeleutherous eis eugeneian agei, prokathairon men autous heterai tini praxei kai didous autois to ton chryson daktylion dikaion, hysteron de eis auten epanagon ten physin ten doulon te kai eleutheron ex arches me diakrinasan all' eleutheron ten anthropou poiesamenen gonen, houto de kai hemeis touton de ton tropon epinooumen toi pragmati. 
cleansed, that is, from the blemish of his servile origin. Justinian speaks of this procedure as coming down to him from his predecessors, and we have no reason to doubt his word on this point. ${ }^{315}$ The grant reestablishes man's natural birthright, and that is also the object of the new grant of legitimation. The idiom of the model grant of freebornship is transferred to the grant of legitimation, the latter like the former being a natales restituere: the father of bastards, Justinian ordains, shall be allowed to invoke the Emperor and thus "to restore his children to nature."316

A year later, in a consolidating statute regarding bastards, the tenet of the primeval, universal freedom and legitimacy appears twice, first towards the beginnng, in a somewhat general survey, ${ }^{317}$ then again in the chapter setting forth the method of legitimation by rescript. Here Justinian almost word for word repeats the explanation given on the earlier occasion-that this method is analogous to the grant of freebornship; that once, under the exclusive reign of natural law, all men were born free and legitimate, slavery and bastardy being the result of war and concupiscence; and that the same passions call for the same remedy, his predecessors having found it for slavery and he applying it to bastardy. ${ }^{318}$ What does not recur is the reference to purification by means of "the golden rings" preceding the grant of freebornship. No wonder seeing that this preliminary measure has no correspondence in the legitimation by imperial rescript introduced by Justinian.

Also in 539, Justinian decisively enlarged the circle of those obtaining freebornship. He enacted that henceforth, on manumission, a slave would automatically have "the right of the golden rings and of restoration to free birth," no special grant being needed. 319 To be sure, he safeguarded to some extent the patron's position: in particular, reverence and gratitude were still to be shown him. Essentially, though, any freedman was now freeborn, a further approximation to the ideal state of the world. In the Preface to the statute Justinian proclaims that, as all goods given him by God are perfect,

315 It may be as early as Commodus. As mentioned supra note 289, from Commodus onwards the "golden rings" no longer implied a knighthood (Mommsen). This puzzling development might be explicable by the fact that a main function of this privilege was now to be the preliminary step to natales restituere. The double procedure is presupposed in Novella 18.11, of A.D. 536, where a man who has children from a slave woman manumits mother and children and then petitions on their behalf "both the right of the golden rings and restoration of native conditions." The law uses palingenesia for "restoration of free birth": see infra, pp. $72 \mathrm{f}$.

316 Novelin 74.7, 2 pr. The fullest version is in 2 pr.: tous nothous autou paidas apokatastasai tei physei kai tei anothen eugeneiai te kai gnesioteti, "to restore his bastard children to nature and to pristine ingenuitas and legitimacy." Eugeneia, ingenuitas, here signifies, not freebornship, but as, e.g., in CoDEx 11.68.4, Valentinian, Valens and Gratian, A.D. 367 (?), the status of a free Roman in a family governed by the civil law.

317 Novelia $89.1 \mathrm{pr}$.

318 Novella 89.9 pr.

310 Novella 78. 
so he holds that the freedom given to a slave should be made pure, incorrupt, and perfect. Already ten years before, in 529, he had decreed that if a patron renounced his hold over a freedman, the latter was to be more or less in the position of one having obtained "restoration of free birth." 320

Two terminological features underline Justinian's particular interest in the conferment of freebornship. First, it is he who, to the traditional natales restituere, "to restore free birth," adds the nominal phrase natalium restitutio, "restoration of free birth"; it is found in the statute of 529 about a patron's renunciation of his privileges. ${ }^{321}$ This coinage reflects increased systematic thinking about the institution, also a feeling of respect for it. Modern writers without exception use the nominal phrase even when concerned with earlier centuries. I have little doubt that this antedating of the weighty-sounding designation has contributed to the antedating of the imperial grant. ${ }^{322}$ If Pliny asked Trajan about natalium restitutio, ${ }^{323}$ the temptation to think of the discretionary elevation of a man of no origin is far greater than if he asked (as he did) more modestly whether he might sit de natalibus restituendis.

Secondly, in Justinian's Greek legislation, both on legitimation and on manumission, several times "restoration of free birth, native conditions" is represented by dikaion paliggenesias, literally, "the right of palingenesia, regeneration, rebirth."324 I have already quoted instances of the belief, not uncommon in antiquity, that a man might undergo a second, supernatural birth. ${ }^{325}$ Admittedly, as a glance at the dictionaries will show, the word

320 Codex 6.4.3.3: the patron lost his right to the succession though he did remain entitled to reverence - which, at that time, i.e., prior to Novella 78, was not due after "restoration to free birth" proper. On what the reform introduced in Codex 6.4.3 did to the legislation on price in the contract of sale, see Daube, Generalisations in Digest 18.1, 1 Studi Arangro-Ruiz 192ff. (1952), and Zur Palingenesie, 76 Zeitsghrift der SavignyStiptung (1959) (Roman section) $177 \mathrm{ff}$.

321 CoDex 6.4.3.1, 2.

322 Cf. supra, pp. $57 \mathrm{ff}$., especially p. 62.

323 See supra note 290.

324 Novella 18.11 of A.D. 536, 78 rubric, 1, 3, 5, of A.D. 539. This does not entail the extrusion of "to restore to nature": 78.5 .

325 Supra, p. 51 . At this juncture I may add that rebirth plays a remarkably small part in adoption, except for adoption by God. Professor Thomas L. Shaffer of Notre Dame Law School kindly draws my attention to the law of Indiana. He writes:

Today, in reading the Indiana statutes on adoption, I noted a provision dealing with the issuance of new birth certificates in cases where the adoption petitioner asks for a change in the child's name. One section of the most recent amendment to that statute may interest you; this is part of Sec. 2, Acts of 1957, General Assembly of Indiana, ch. 47, which is codified in Indiana Statutes Annotated Sec. 3-125: "When a new certificate of birth is established following adoption, it shall replace the original registration of birth, which shall be filed with the evidence of adoption, and withheld from inspection except by order of a court of competent jurisdiction. The new certificate shall show the actual place and date of birth, except the court may, if requested in the petition duly filed, decree the birthplace of the child as the place of residence of the adopting mother at the time of such child's birth, or at the time of 
palingenesia is not confined to this event. It has many shades of meaning, from distinctly theological ones to such as are hardly weighted that way - it can signify any major fresh start. (Cicero, incidently, in an otherwise Latin letter, uses it of his own "renaissance," his reinstallment after exile.) ${ }^{\mathbf{3 2 6}}$ However, in view of what we have just noticed - and, indeed, of what we shall yet notice - concerning Justinian's attitude to bestowal of freebornship, it is safe to say that his introduction of this term is not a casual matter. It indeed joins with the concept of attainment of a personal free birth rather than that of participation in the abstract free birth of the ideal law of nature. ${ }^{327}$ There is no reason why Justinan should narrowly adhere to one construction of natales restituere: after all, he admits both into the Digest.

Before going on to the source of his fascination with bestowal of freebornship, it is useful to dispose of an episode from Plutarch's Life of Lucullus, which, at first sight, might look like alluding to the contrast between freedmanship and the primeval pure freedom of all men but, in fact, does nothing of the sort. 328 When Lucullus in 71 B.C. captured Amisus, the grammarian Tyrannio (the Elder) was among the prisoners. Murena, then serving as legate, asked to have him as his prize and, having got him, manumitted him. Lucullus considered this procedure mean: such a scholar; he held, ought not to have been enslaved and manumitted since "the gift of seeming freedom was a taking away of the original one." 329

The proper interpretation of the passage is as follows. It would have been open to Murena not to treat Tyrannio as a slave at all. Lucullus, Plutarch informs us, of a nobler disposition than his legate, simply allowed such citizens of Amisus as wished to live on there to do so, and to many Greeks among them he even gave clothes and money. He could have made slaves of all of them, and freedmen tied to him by subsequently releasing them, but he

the filing of the petition, provided such child was born within the continental limits of the United States and is less than six years of age at the time of said petition." This provision replaced ch. 146, Acts of 1941, Sec. 11, which provided on this point: "At any time after such recording of said certificate of adoption a certificate of birth shall be issued, upon request, bearing the new name of the child as shown in the certificate of adoption, the names of the foster parents of said child, . . . and there shall be no difference or distinction by way of color, size, or general substance of birth registration cands or birth certificates, whether the child be legitimate or illegitimate, adopted or of natural parentage." The old statute provided that the original birth registration remain a public record, but seems clearly to have contemplated also a sort of new birth by court decree; the new statute contemplates a new birthplace by court decree; it is not clear to me whether the adopted status of the child appears on the record under the new statute.

326 Grareo, Ad Atticum 6.6.4.

32T Significantly, in Novella 18 and 78, with the more personal palingenesia, we find no lengthy description of primeval equality.

928 Plutarch, Lucullus 19.7.

329 Aphairesis gar en tes hyparchouses he tes dokouses eleutherias dosis. 
refrained. 330 Murena ought to have treated Tyrannio in the same way, simply leaving him free. Instead of which he made him his slave, so that, on manumission, he became his patron. Tyrannio was now free indeed, but this "seeming," factitious freedom was not his "original," genuine, unencumbered one; it was merely freedmanship. Manifestly, this has nothing to do with the doctrine of equality in the golden age. The contrast is between Tyrannio's natales, his freedom from birth, and the status Murena's meanness substituted for it, a status "seeming," "considered" to be freedom by virtue of a legal transaction, a manufactured, lesser freedom, freedmanship.

25. Creation of a Freeborn Citizen and Rehabilitation of an Actress by Rescript. - In a way, a strange way, natales restituere reaches its climax some six years before Justinian's accession to the throne, in Codex 5.4.23, enacted between 520 and 523 at Justinian's instance by his uncle Justin, then sole Emperor, in order to enable Justinian to marry Theodora, a penitent actress. (Justinian was then getting on to forty.) In this law the principle of natales restituere is carried outside its original province in a far bolder manner than in the later Novel, considered above, where it is transferred to legitimation. It is here extended from problems of descent to the moral sphere and the status of man as determined by his chosen way of life. While the influence of Marcian's construction is strong, the thought of recovery of the individual's own unspoilt past is also unmistakably present. The whole law is very theological and has received too little attention on the part of historians of Christian doctrine: it would surely throw light, for instance, on some controversial questions regarding sixth-century ideas on penitence. I must confine myself to points of direct interest. ${ }^{330 a}$

Prior to this law, a citizen of senatorial rank was not allowed to marry an actress. ${ }^{331}$ Theodora had been one, and once an actress always an actress. ${ }^{332}$

330 Plutarch, op. cit. supra note 328 , at 19.6. A commander had a good deal of discretion in these matters. A story commemorating Scipio's (Scipio Africanus Major) generous behavior after the capture of New Carthage in 209 B.C. is told in Livy 26.50, Gellius 7.8.3ff. and Polybius 10.19. For details of the law, see Vogel, Zur rechtlichen Behandlung der römischen Kriegsgewinne, 66 Zertschrift Der Savigny-Stiftuno (1948) Rom.Abt., $398 f$.

330a For further details see now my Pope John Lecture, delivered in Spring, 1967, at the Columbus School of Law of the Catholic University of America at Washington, D.C. and published in 16 Catholic University of America Law Review 380 (1967).

331 Codex Theodosianus 4.6.3 [ = Codex 5.27.7] Constantine, A.D. 336, Novella Marciani 4.3 [= Codex 5.7.2] Valentinian and Marcian, 454.

332 E.g., Digest 23.2:44, Paul I ad legem Juliam et Papiam: a member of a senatorial family may not marry, the statute prescribes, "one who herself or whose father or mother practices or has practiced stagecraft," quae ipsa cuiusve pater materve artem ludicram facit fecerit. This permanency of the label, however, while applying wherever social status is in question, is not absolute. I shall not go into this complicated business, except to give an illustration relating to prostitutes. To them, too, the label once acquired stuck for good (e.g., Digest 22.5.3.5, Callistratus IV de cognitionibus, 23.2.43.4, Ulpian I ad legem Juliam et Papiam; compare Tabula Heraclsensis 122f.), but again only in matters having to 
Justin (the hand is the uncle's, but the voice is the nephew's) in an introductory paragraph explains that these women should not be left without hope, an inducement to give up their objectionable profession. In this way, the Emperor can imitate the clemency of God, always willing to accept the penitent sinner and "lead him back to a better state," ad meliorem statum reducere. If the Emperor fails to act thus, he himself will not be worthy of divine forgiveness. ${ }^{933}$ So far the motivation concentrates on forgiveness and, with it, on the forgiven person's reinstatement (reducere) in his former, guiltless condition.

In the next paragraph Justin brings in, drags in, the rules of natales restituere. A far-fetched comparison indeed. It would be wrong, he argues, if a freedman could be helped but not a penitent actress - quite forgetting that the former is innocent whereas the latter is guilty: "As it is unjust that slaves to whom freedom has been given can by imperial relief be restored to their native conditions and, after receiving such an imperial grant, live as if they had never served as slaves but had been born free, whereas women who, though they have concerned themselves with stage plays, yet later, spurning this evil condition, have turned to better intention and escaped from their dishonorable profession, have no hope of an imperial grant which would lead them back to that state in which, had there been no sinning, they could have remained."334

Here we have before us a blend of theories concerning a rise in status. On the one hand, as far as a freedman's promotion is concerned, Marcian's teaching is adopted, just as it is, we saw above, in several later statutes of

do with social status, not, say, for the purpose of the tax on the profession. When Caligula wished to tax even ex-prostitutes, a special clause had to be appended to the statute, a clause which Suetonius condemns (Gaius Caligula 40). As often, there is a serious problem at the bottom of a vulgar joke. Elderly lady: "Mr. Smith, you should talk to your wife, she has called me a _-" Mr. Smith: "No use talking to her, that's her way. I've been out of the army for thirty years and she still calls me Colonel."

333 The Emperor holds that one should by no means eis spem melioris condicionis adimere, ut ad eam respicientes improvidam et minus honestam electionem facilius derelinquant; nam ita credimus dei benevolentiam et circa genus humanum nimiam clementiam quantum nostrae naturae possibile est imitari, qui cottidianis hominum peccatis semper ignoscere dignatur et paenitentiam suscipere nostram et ad meliorem statum reducere; quod si circa nostro subiectos imperio nos etiam facere differamus, nulla venia digni esse videbimur, "deprive them of hope for a better condition, in order that, looking to it, they may more readily give up their ill-considered and dishonorable choice; for thus we believe that we are imitating God's benevolence and his measureless clemency towards mankind as far as is possible to our nature, seeing that he ever deigns to pardon the daily sins of men and to receive our penitence and lead us back to a better state; which if we fail to do too to those subject to our power, we shall appear worthy of no pardon."

$334 \mathrm{Cum}$ iniustum sit servos quidem libertate donatos posse per divinam indulgentiam natalibus suis restitui postque huiusmodi principale beneficium ita degere quasi numquam deservissent sed ingenui nati essent, mulieres autem quae scaenicis quidem sese ludis immiscuerunt, postea vero spreta mala condicione ad meliorem migravere sententiam et inhonestam professionem effugerunt, nullam spem principalis habere beneficii quod eas ad illum statum reduceret in quo, si nihil peccatum esset, commorari potuerint. 
Justinian: the personal free birth of a freedman "restored to his native conditions" is a fiction; he is looked on, the text says, "as if he had been born free." On the other hand, the grant envisaged for a penitent actress will mean her actual reinstallment in her previous, sinless position (ad illum statum reducere in quo commorari potuerint), in analogy to what happens when God forgives. There is less of a discrepancy than might appear at first sight. Marcian's fiction, it will be recalled, flows from an effect of the grant which is regarded as real- the turning of the grantee into a man freeborn under the ideal dispensation valid for all. In the case of forgiveness, restoration of the sinner to his own, personal state prior to the sin and restoration of the sinner to the state of innocence in the golden age more or less coincide; the former is tantamount to the latter.

The Emperor goes on to proclaim that henceforth penitent actresses may apply for an imperial ordinance granting full marriage rights. Upon such a privilege, the husbands "may be confident that the marriage will be as valid as if they had taken them to wives with no earlier dishonorable life." 335 How far this implies a fiction, how far the past is thought of as just nonexistent, is difficult to say: the particle quasi, here translated by "as if," is so ambiguous.

It is the immediate continuation which takes up from the opening argument the association with natales restituere, or rather the synonymous natales reddere. ${ }^{336}$ "For, all blemish being utterly wiped out, and these women being, so to speak, handed back to their native conditions, we wish that neither shall a dishonorable designation henceforth attach to them nor shall they be any different from those who have committed no such sin." 337

The comparison with natales restituere is here pushed to its limit. In the motivation, we have seen, Justinian claims that it would be an injustice to offer a route to the heights to freedmen and none to penitent actresses. Here, a penitent actress rehabilitated is said to be, in a sense (quasi, "so to speak"), like a freedman who has been granted freebornship; she is, in a sense, "returned to her native conditions." From the context it is probable that, at this point, the lawgiver is harking back to that doctrine which assumes that a freedman granted freebornship is actually born free, is (in the words of Modestinus) "as if, being made freeborn, he had not in the meantime suffered the blemish of slavery." 338 Just so, a penitent actress accepted by the Emperor is actually re-created, recovers the untainted life that was hers at

${ }^{335}$ Ita validum huiusmodi permanere matrimonium confidentibus quasi nulla praecedente inhonesta vita uxores eas duxerint.

336 See supra note 292.

337 Nam omni macula penitus direpta et quasi suis natalibus huiusmodi mulieribus redditis, neque vocabulum inhonestum eis inhaerere de cetero volumus neque differentiam aliquam eas habere cum his quae nihil simile peccaverunt. ${ }_{338}$ See supra, pp. 66f., on Digest 40.11.5.1, Modestinus VII regularum. 
birth. It will be noted that, in her case, the notion restituere (or reddere) natales, "to restore (hand back) the native conditions," fits whether we think of her as reinstated in the primeval, universal sinlessness of mankind or in her own, personal sinlessness before she became an actress. In the case of a freedman, where it is a question not of a moral lapse but of descent, the phrase fully suits only reinstatement in the abstract, primeval undividedness of rank; there is no personal free birth to reinstate him in. As pointed out above, ${ }^{339}$ this may indeed have been among the considerations which. led to the understanding (by Marcian) of the grant of freebornship as the man's restoration to the original, ideal world.

A rehabilitated actress may no longer be called an actress, a scaenica: this predicate is meant, of course, by the "dishonorable designation" from which the statute releases her. Indeed, there shall be no difference between her and any respectable woman. The formulation is not absolutely clear, but apparently the label is removed only for the future; it could still be said that she was once a scaenica. Complete annulment of the past is simply not attainable. Maybe she is thought of as having sinned in a different life.

In one respect, however, the language is as unambiguous as can be: "all blemish is utterly wiped out." The best MSS. have direpta, "torn up." Mommsen suggests dirempta, "eliminated." Direpta is certainly unusual, and the fact that an important MS. (Casinas 49) has direptam also speaks in his favor. Yet a very forceful, striking expression may have been deliberately chosen. I have translated neutrally with "wiped out." 340 In a parallel clause further on in the law the verb is abolire, "to abolish." There is no doubt as to the sense: as a result of the imperial ordinance, the woman is absolutely pure.

As already remarked, it is a strange undertaking to present the case as an extension of the principle underlying the conferment of freebornship. But we can now see the point. That institution was the nearest model of an imperial grant with a direct effect on a person's past, the nearest legal model that would render plausible the - prima facie extraordinary - denial of any blemish in a rehabilitated actress. (The term macula for "blemish" is well chosen: it is traditionally associated with the servile status as well as misdeeds reflecting on a person's character. It occurs in the passage just cited - "as if he had not suffered the blemish of slavery." $)^{341}$ Justinian, through his uncle,

339 See supra, p. 69.

340 It would be interesting to find out what is the history behind the interchangeability of dirimere and diripere assumed in a late medieval glossary on a work by Balderic of Bourgueil: see Du Cange, 3 Glossarium mediae et infimae Latinitatis 126 (1883-7).

341 Compare also, e.g., Codex 7.16.9, Diocletian and Maximian, A.D. 293. In Codex Theodosianus 4.6.3. [= Codex 5.27.1 pr.] Constantine, A.D. 336, a senator who enters a forbidden marriage is declared subject to the macula infamiae, "the blemish of infamy." 
is here at work for his great love. She must be flawless - hence this tour de force.

I have the impression that some scholars believe that Justin, in the clause mentioning natales, is according freebornship to rehabilitated actresses who are freedwomen. Earlier legislation prohibited marriage between a man of senatorial rank and a freedwoman. In the opinion of these scholars, Justin here legalizes such a union where the freedwoman is a penitent actress whose blemish has been removed. ${ }^{342}$ But this is an error. The law contemplates only freeborn women; Theodora's free birth was never in doubt. The extension to freedwomen came only some twelve years later, under Justinian. ${ }^{343}$ Let me reiterate: what the clause mentioning natales does is to liken the reinstatement of penitent (freeborn) actresses to the bestowal of freebornship on persons of servile origin: a reinstated actress, like a freedman made freeborm, is - up to a point - a new creature, her degradation a bad dream.

Bury is skeptical about Procopius's statement that the law was needed for Justinian's marriage; he points out that, as is reported by Procopius himself, Theodora had been made a patrician some time before - and a patrician, Bury argues, even if she had once been on the stage, was marriageable by a senator. ${ }^{344}$ Assunta Nagl says that Bury gives no reason for his doubts. ${ }^{345}$ But surely, this elevation to the patriciate is a reason, though, as we shall soon see, a bad one. Miss Nagl's comment is all the stranger as she does accept Bury's - erroneous - view that from the moment Theodora became a patrician, her profession was no longer an obstacle in the way of a marriage with Justinian. Vasiliev is remarkably confused. ${ }^{346} \mathrm{He}$ adopts Bury's position: having become a patrician prior to this law, Theodora no longer needed it; she was already fit for a senatorial marriage. As proof that, as a patrician, she could marry a senator, he cites Codex 5.4.23.4, which indeed provides that an actress receiving a high dignity is equal to one who, penitent, is granted an imperial rescript; but-the provision is part of the very law we are discussing, the law enacted by Justin. There is nothing to suggest that it applied at an earlier date, when Theodora was first honored.

Here lies the fallacy of Bury's argument. What he and those dependent on him fail to appreciate is that, when Theodora became a patrician, though

\footnotetext{
342 VAsiliev, JUstin the First 393 (1950): "the latter (penitent actresses) shall be regarded as free women"; KAser, 2 DAs Römische Privatrecht 113 (1959): "marriage with former actresses, freeborn or manumitted."

343 Codex 1.4.33.2, A.D. 533. It would lead too far afield to discuss this interesting statute.

844 Bury, 2 History of the Later Roman Empire 29 (1923), referring to B. Panghenko, O Tainor istori Prokopita 74 (1897). The reference is to Procopius, AnecDOTA 9.30 .

345 "Theodora" in Paulys Realencyclopädie, 2nd ser., vol. 5 (1934) 1778.

346 VASILIEV, op. cit. supra note 342 , at 100ff, 389, $392 \mathrm{ff}$.
} 
the dignity was no doubt recognized as eliminating the blemish of servile provenance (which she, however, did not bear), it did not yet eliminate a blemish like that of the stage; at least there was no definite ruling to that effect - the question, I guess, had never become acute. It is the very law here under review which, in a special paragraph, lays down that women receiving a dignity from the Emperor are to be equal to those who obtain a rescript. Indeed, the conferment of such a dignity is to remove also any blemish other than a theatrical career (say, the recipient had kept a tavern) normally an impediment to a senatorial marriage. ${ }^{347}$ (The radical nature of the suppression of any other blemish is brought out by the term used, penitus abolere, just as in the case of the blemish of the stage.) ${ }^{348}$ Legislation, then, was needed.

Two questions arise. First, why did Justin - or Justinian - bother about penitent actresses, instead of simply legislating that a woman promoted to the patriciate is cleared of her past? That would have done for the immediate purpose of the proposed union. The answer is that the lawgiver was inspired by genuine religious and moral fervor. Theodora's rise from the depths was not to be covered up; on the contrary, others were to be encouraged to emulate her. The legislation was ad hoc in the sense that Justinian's match was the occasion for it. But it was genuinely desired that the example should be followed. This is not mere speculation: the subsequent legislative policy of Justinian bears out what I am saying.

The second question flows from the answer to the first. Why, once it was decided to make available this wide access to senatorial marriage, a request to the Emperor acknowledged by a rescript, did Justin nevertheless add the paragraph providing elevation to high dignity - the patriciate, for instance - with the same effect? Surely, this was, above all, a gallant gesture to Theodora. She was to be spared the procedure of having to apply for a favor and obtaining no more than what she asked for. Her patriciate had been given her, the Emperor indicates, as a free manifestation of his goodwill; at least this is what I think he is conveying when he speaks of women "who,

s47 Similes vero tale merentibus ab imperatore beneficium mulieribus illas etiam esse volumus quae dignitatem aliquam, etsi non serenissimo principi supplicaverunt, ultronea tamen donatione, ante matrimonium meruerint, ex qua dignitate aliam etiam omnem maculam per quam certis hominibus legitime coniungi mulieres prohibentur aboleri penitus oportet. "To the women being rewarded by the Emperor with this privilege [the rescript to help them from their past as actresses] we wish to equate those who, though they did not supplicate to the Most Serene Emperor, have been rewarded with some dignity by an unsolicited gift before marriage; by which gift it is meet that also any other blemish on account of which women are prohibited from being united with certain men, be utterly abolished."

348 I do not know why VAsrurrv, op. cit. supra note 342, at 394 represents the statute as using stigma at this point instead of macula. No MS. has stigma. Not that it matters much. 
without supplicating to the Most Serene Emperor, have nevertheless been rewarded with some dignity by a spontaneous gift." By adding this paragraph which declares recipients of an imperial honor suitable partners for senators, Justin succeeded in combining his general religious-moral aim with personal considerateness. It should be observed that this provision concerning women dignitaries is distinctly subsidiary to that concerning women petitioners. It is the latter whose fitness for senatorial unions is established in the principal part of the statute; and it is the former who, in a relatively short paragraph, are equated to them. It is not the latter who are equated to the former.

It is just conceivable, however, that there is a little more to this subsidiary rule. Elevation to a dignity wipes out, we have just found, not only the blemish of the stage but also any other blemish obstructing a noble marriage. The rescript cures only the blemish of the theater; elevation to a dignity can do more. It is just conceivable that the lawgiver, while unwilling to make blemishes other than the theater generally venial, and therefore keeping them out of the rescript, did deem it wise to ensure that Theodora at least should be eligible for a noble marriage even should the stage not have been her only sin. In the concluding chapter I shall have occasion to say something about reports depicting her as a prostitute. Justin would never admit such a charge; at the same time it may have been considered wise to have a clause which would legalize the marriage whatever view one took.

We have seen that a rehabilitated actress is no longer an actress, is in fact no different from a woman who never lapsed. It is only logical that the law should enjoin that "daughters of such women, if they are born after the cleansing of their mother's former life, are not considered daughters of actresses."349 Among marriages forbidden to senators had been also that with an actress's daughter. From now a daughter born after the mother's rehabilitation is automatically excluded from the ban.

The provision is admirably placed at such a point in the statute as to make it quite clear that it covers rehabilitation by means of a dignity like the patriciate as well as rehabilitation by means of a rescript. The expression by which rehabilitation is referred to is also very general, covering both methods: "cleansing of the former life." Very likely this paragraph was put in with a view to any female offspring that might ensue from Theodora's marriage with Justinian. We know that they hoped for children, though in vain. ${ }^{350}$ The term expurgatio, incidentally, "cleansing," occurs nowhere else in the Roman legal sources - but it will be remembered that we found Justinian

9s9 Filiae huiuscemodi mulierum, si quidem post expurgationem prioris vitae matris suae natae sint, non videantur scaenicarum esse filiae.

$980 \mathrm{Nagl,}$ op. cit. supra note 345 , at 1782 . 
speaking in Groek of a prokathairein, a "purifying beforehand," of freedmen through "the golden rings." 351

Daughters born before rehabilitation, the law adds, need an imperial rescript, which will be granted them if the mother is either rehabilitated or dead, and which will give them marriage capacity "as if they were not the daughters of an actress mother."352 So with regard to them, a fiction will result. ${ }^{353}$ The only daughter, it follows, who remains debarred from a firstclass marriage is one whose mother is alive and unredeemed. The lawgiver knew what he was doing: in this case, the husband would acquire undesirable connections. Theodora's illegitimate daughter from her earlier life, if a noble marriage were intended, would need and be entitled to a rescript. That this daughter was the fruit of her mother's premarital affair with Justinian is claimed by Bury, ${ }^{354}$ but seems incredible to me. The argument from silence alone is overwhelming: there is no testimony lending the slightest support to his conjecture. The question does not affect my conclusions.

26. The Rehabilitation of Theodora: Eros and Agape. - I should like to append some further comments on this statute though they are not required by my subject. The unwarranted dismissal of Procopius's notice that the statute was designed to enable Justinian to marry Theodora leads to a good deal of more basic misrepresentation. For Vasiliev, "the law was merely one step in the progress of the emancipation of women, which goes back to the fourth and fifth centuries and was in accordance with Christian sentiments."355 This is an exaggeration. Certainly the law marks a stage in a more or less steady advance. But that such advance was not its immediate central purpose comes out in many ways. Why were no other female sinners considered worthy of a chance? Why no female sufferers with far better claims and far more comparable to slaves or freedmen? Daughters of women keeping taverns, for example, were included only in a Novel of A.D. 542. ${ }^{356}$

Ex-prostitutes were perhaps never under Justinian entitled to rehabilitation (except if promoted to high dignity, a contingency which, after Theodora, would hardly ever again be of more than academic interest). In the Digest they are still definitely interdicted to the senatorial class, ${ }^{357}$ and it is ex-

351 Novella 74.1, supta, pp. $70 f$.

352 Quasi non sint scaenicae matris filiae.

853 Rigorous insistence on retroactivity of rehabilitation might - though it need not lead to the conclusion that even in this case the mother is in fact no actress; compare supra, p. 67, as to a rejected view about retroactivity of the grant of freebornship.

35. BURY, op. cit. supra note 344 , at 27.

355 Vasnurev, op. cit. supra note 342, at 395.

358 Novella 117.6 .

357 Diges T 23.2.43.4, Ulpian I ad legem Juliam et Papiam. 
tremely doubtful whether, as seems universally held, ${ }^{358}$ the interdiction was lifted by Novel 117 of the year 542.359 Procopius both in his official and secret writings tells us about the seclusion offshore of ex-prostitutes in Justinian's reign. ${ }^{360}$

Beyond question Theodora had led a dissolute life; if we distrust Procopius's secret history, the fact is confirmed by John of Ephesus, a Monophysite who cannot enjoy transmitting anything unfavorable to a benefactress of his party. In law, it would make all the difference whether she had been a prostitute or only come near being one. I believe that she was free with her favors and not averse to earning money that way, but that she was not technically a prostitute. ${ }^{361}$ At any rate, the long, principal portion of Codex 5.4.23 is evidently meant to convey the impression that she was guilty of acting only, and the comparative lightness of this lapse is cleverly insinuated by the phraseology. ${ }^{362}$ Moreover, the continued harshness of the legal order in respect of prostitutes may be partly owing to the determination to avoid confusion: Theodora had never been that low. Doubtless in practice this distinction between actress and prostitute was sometimes blurred, especially between a variety or circus actress and a prostitute slightly better than "infantry."363 But the law differentiates most definitely, and the principal part of Justin's statute is emphatically - overemphatically - about actresses only. I argued above that, conceivably, in the clause concerning the rehabilitation of a patrician, the removal of all blemishes indiscriminately - not only of that caused by acting - may be intended inconspicuously to legalize Theodora's

358 Buckland, Textbook of Roman Law 115 (3rd ed. by Stein [1963]); Kaser, op. cit. supra note 146 , at 113 .

359 Novella 117.6 allows the women defined as "abject" in Codex Throdosianus 4.6.3 [= Codex 7.27.1 pr.] Constantine, A.D. 336; Novella Marciani 4.3 [= Codex 5.5.7.2], Valentinian and Maximian, 454. But these are freedwomen, tavern keepers, the daughters of tavern keepers and the like - not prostitutes.

360 The difference between the official account in Procopius, Ktismata 1.9.1ff. and the secret one in Procopius, AnecDota 17.5f. is priceless.

361 For a legal definition see Dioest 23.2.43pr.ff., Ulpian I ad legem Juliam et Papiam.

362 Indigna honore conversatio, "company incompatible with honor"; improvida et minus honesta electio, "ill-considered and dishonorable (less honorable) choice"; scaenicis sese ludis immiscere, "to involve oneself with the stage"; mala condicio, "evil condition"; inhonesta professio "dishonorable profession"; mala et inhonesta conversatio, "evil and dishonorable company"; inhonesta vita, "dishonorable life" - none of these expressions are very harsh, especially when we consider what scathing language the laws can use. The women are said to be impelled by sexus imbecillitas, "the weakness of their sex." The term recurs only in Digest 16.1.2.2, Ulpian $X X I X$ ad edictum, in connection with a senatusconsult forbidding women to undertake liability for others. Justin may well be intending to evoke the idea that women become actresses under pressure from selfish men. Compare, e.g., Codex 1.4.33, Justinian, A.D. 534, or also, with regard to prostitutes, Procopius, Ktismata 1.9.2f. Digest 16.1.2.2 is often held interpolated (e.g., Beseler, Beiträge, vol. 2, 1911, 106, vol. 3, 1913, 106, Voat, Studien zum Senatusconsultum Velleianum $(1952), 8$ ) without good reason, I think, but it does not matter.

36s Peze in Greek: Procopius, Anecdota 9.11; see translation by Dewing, Procopius 105 (Loeb Classical Library, vol. 6 [1954]). 
marriage even should she be deemed guilty of worse than acting. Procopius, who surely knew Codex 5.4 .23 well and understood its religious-moral component, is very nasty in stating that this law made possible the marriage between men of senatorial rank and prostitutes $;^{364}$ though, if my suspicion about that paragraph concerning women dignitaries is justified, it is not surprising he was alive to that aspect and made the most of it.

Whether or not Biondi subscribes to Bury's suggestion that Justinian did not need the law for his marriage is not clear; at all events, he gives no hint at the possibility of any selfish motive. In his book on Justinian as a Catholic ruler, he confines himself to the affirmation that, contrary to Procopius's malicious report, the law is "a veritable hymn to the redemption of women and the benevolence of God, whom the lawgiver seeks to imitate"; 365 and again, in his magnum opus on the Christian law of Rome, though he quotes the statute more than half a dozen times, he never once makes mention of its ad hoc object - it is just an example of Christian pity for the sinner and facilitation of repentance. ${ }^{366}$

He cites the words, "We hold that their lapses should be remedied by a suitable means, and we ought not to deprive them of the hope for a better condition, in order that, looking forward to this, they may more readily give up their ill-considered and shameful choice," see in these phrases the distant echo of the gospel episode of the adulterous woman (John 8.3-11) ?"368 Aristotle in his Art of Rhetoric counsels that, unless the answer desired to your rhetorical question is $100 \%$ obvious, you should at once state it yourself. ${ }^{369}$ Biondi disregards this advice, to his cost. I do not see it, or at least ' $I$ find there is room for doubt: the passage from John deals with an adulteress caught in flagranti, and furthermore; there is no significant verbal affinity whatever between it (i.e., its Latin versions) and Justin's law. (The words mulier and peccare are common to both, but they are too unspecific to be relevant. For the rest, the dominant notions in John are accusare and condemnare, "to accuse" and "to condemn," 970 and these are absent from the statute.) Biondi continues: "Towards those women the

364 Procopius, Anecdota 9.51.

365 Biondo Biondi, Giustiniano Primo Principe a Legislatore Cattolico $62 f$. (1936).

868 Biondo Biondi, Il Dirttto Romano Cristiano, vol. 1 (1952) 138, vol. 2 (1952) $164,166,168$, vol. 3 (1954) 86, 326, 427, 437.

36т Cum competenti moderatione sublevandos (lapsus) esse censemus mimimeque eis spem melioris condicionis adimere, ut ad eam rem respicientes improvidam et minus honestam electionem facilius derelinquant.

s68 Browdi, op. cit. supra note 366 , at vol. $2,166$.

360 3.18. I am aware that Aristotle has in mind a speech to an audience that can intervene - not a piece of writing.

370 Ubi sunt qui te accusabant? nemo te condemnavit? Nec te condemnabo. 
lawgiver feels not contempt but humane understanding calculated to bring about penitence and redemption." Ambiguous language, "those women," quelle donne, since, as a matter of fact, the kinds of women contemplated in the pericope de adultera and this law are quite different. ${ }^{371}$

A similar rhetorical question is put a little further on. He writes that the law provides for the rehabilitation of actresses who - he quotes - "spurning their evil condition have turned to a better intent and have fled their dishonorable profession, have embraced a worthier life and have turned to decency."372 "Who does not hear," he asks, "in these provisions the echo of the gospel warnings concerning prostitutes who convert (Matthew 21.32)?'373 When we look up Matthew, we find that publicans and prostitutes believed the Baptist; the Pharisees, though offered more evidence, showed no repentance: Venit enim ad vos Joannes in via justitiae, et non credidistis $e i$, publicani autem et meretrices crediderunt ei, vos autem videntes nec poenitentiam habuistis postea, ut crederetis ei. I cannot hear the echo.

The law under notice is permeated by the spirit of Christianity and rich in categories deriving from the New Testament, directly or indirectly. ${ }^{374}$ Yet overidealization ultimately enhances neither the stature of Justin or Justinian nor the value of their legislation as an exemplum, as a stimulus and guide not to mention what it does to the gospel. What is most moving about the law is the peculiar fusion of self-interest and generosity. (Nero had proceeded very differently when he planned marriage with a freedwoman - and even that association is not devoid of deeply touching features. ${ }^{375}$ ) The primary impulse comes from Justinian's passionate resolve to marry Theodora; a splendid resolve, nothing wrong in it, but still a personal cause. He has, however, thought profoundly about their relation, about why they find themselves confronted by such difficulties, and about why it is right to remove them. The law makes use of what he has learnt; and while assisting him, it extends relief to many sufferers and, indeed, propagates sentiments of a kind that must inevitably lead to further progress. No point in dehumanizing this measure. Some fifteen years later, at the age of fifty-five, in the Novel which introduces legitimation by rescript, he avowed: "For we know, though we are lovers of chastity, that nothing is more vehement than the fury of love."376

371 Biondi himself offers a detailed exposition of the sanctions on adultery. $O p$. cit. supra note 366 , at vol. $3,473 \mathrm{ff}$.

372 Spreta mala condicione ad meliorem migravere sententiam et inhonestam professionem effugerunt. . commodiorem vitam amplexae fuerint et honestati se dederint.

373 Brondr, op. cit. supra note 366 , at vol. 2, 168.

374 Though compare also sentiments like Seneca, De clementia 1.7.1f.

375 Surtonius, Nero 50: "His nurses Egloge and Alexandria, with his concubine Acte, deposited his remains."

378 Ismen gar, ei kai sophrosynes esmen erastai. . ouden einai manias erotikes sphodroteron. 